UNIVERSITAT

POLITĖCNICA

DE VALÈNCIA

Departamento de Biotecnología

Identificación y caracterización de la familia de factores DBP, nuevos reguladores de la expresión génica en plantas

María José Castelló Llopis

TESIS DOCTORAL

Directores:

Pablo Vera Vera

Jose Luis Carrasco Jiménez

Valencia, 2008 

Pablo Vera Vera, Profesor de Investigación del C.S.I.C., y Jose Luis Carrasco Jiménez, Investigador Postdoctoral de la Universidad Politécnica de Valencia

\section{CERTIFICAN:}

Que la presente memoria titulada "Identificación y caracterización de la familia de factores DBP, nuevos reguladores de la expresión génica en plantas" ha sido realizada por María José Castelló Llopis bajo nuestra dirección en el Instituto de Biología Molecular y Celular de Plantas (U.P.V.-C.S.I.C.), y constituye su Memoria de Tesis para optar al grado de Doctor por la Universidad Politécnica de Valencia.

Y para que así conste a todos los efectos oportunos, firman el presente certificado en Valencia, a veintidós de Octubre de dos mil ocho. 



\section{AGRADECIMIENTOS}

Estos cuatro años de trabajo me han aportado no sólo un gran enriquecimiento científico, sino que además me han permitido conocer a un gran número de personas con las que he compartido cada uno de los momentos de esta aventura. Por ello mi deseo de mostrar mi agradecimiento hacia todas ellas por el apoyo prestado.

En primer lugar, mi más enorme y sincero agradecimiento a mis directores de tesis, Pablo Vera y José Luis Carrasco. A Pablo Vera por la oportunidad de conocer el mundo de la ciencia, y además por depositar en mí su confianza y darme su apoyo en todo este tiempo. Necesitaría una sección exclusiva para expresar mi agradecimiento a Jose, y aún así no encontraría las palabras adecuadas para poder expresar todo lo que le debo. Gracias por tu dedicación exclusiva para que este trabajo haya podido llegar a su fin. Gracias por compartir conmigo tus infinitas virtudes, tanto a nivel profesional como personal, eres un gran ejemplo a seguir.

A Sami Irar y Montserrat Pagés por la realización del análisis proteómico. A Juan Antonio García, Karen Browning, Christophe Robaglia, Andrew Maule y Fernando Ponz por facilitarnos material para el desarrollo de este trabajo.

El agradecimiento más especial para mis compañeros de laboratorio, mi pequeña familia en Valencia, los que han tenido que soportarme día a día y que han hecho que nunca olvide esta etapa de mi vida. En primer lugar agradecerle especialmente a mi Lore la confianza, amistad y complicidad que me ha brindado desde el primer momento y por dejarme compartir tantas cosas con ella. A mi gran confidente y amigo Vicente, por estar siempre a mi lado en los buenos y malos momentos, gracias por aguantarme tanto, por tu optimismo y generosidad. A Albor, por ser una persona tan especial y por escucharme durante estos cuatro años. A Anita por su jovialidad y simpatía, y por los buenos momentos que hemos compartido fuera del laboratorio. A David por conseguir sacarme una sonrisa en el momento adecuado gracias a su ingeniosidad. A Mariajo ("la mami") por arroparme en todo momento y por aportar su alegría y su gracia a cada día de trabajo. Al "chungo" de Javi por poner su toque especial de humor en el laboratorio. A Silvia por querer participar en la aventura DBP y por ser una excelente compañera. A Astrid por interesarse por mi trabajo y por sus consejos. A Loli por la ayuda prestada y por facilitar la tarea de cada día. Finalmente, expresar mi gratitud a las últimas incorporaciones del laboratorio, Imane y Begoña.

Muchas gracias a todos por dejarme compartir con vosotros tantas cosas dentro y fuera del laboratorio, mi más sincero agradecimiento.

Y por supuesto, a los que ya no están pero que han compartido parte de estos cuatro años conmigo. Siempre quedará en mi recuerdo mi amigo Alberto por poner ese toque caribeño y guasón a mis días en el laboratorio, Emilio por compartir los inicios conmigo, Susi por estar ahí 
en casi toda esta aventura y a los que en algún momento fueron partícipes de esta vivencia, Pablo Tornero, Brande Wulff, Luis Fuster, María José Gil, Lucía Pérez, Isabel Gavidia, Pedro Molina y las canarionas Noe y Elsa.

No puedo olvidarme de las personas del instituto, que aunque no formen parte del grupo del laboratorio, han compartido muy buenos momentos conmigo. Muchas gracias Aurora por brindarme tu amistad desde el primer día. Muchas gracias a Juanvi, Leti, Fernando, Manu, Arturo y Mil por compartir las horas de la comida y las tertulias del café.

Agradecer también la ayuda del personal del invernadero y de los servicios de secuenciación y microscopía del IBMCP.

En último lugar no puedo dejar de mencionar a aquellas personas que, aunque ajenas a este mundo, siempre han estado a mi lado y me han mostrado su apoyo y cariño en todo momento. Mi infinito agradecimiento a los dos tesoros de mi vida, mis padres Emilio y Pura, y por supuesto a toda mi familia. $Y$ a las que siempre han apoyado mi ilusión de manera incondicional, muchísimas gracias Vane, Inma, Lydia, Sandra, Marián, Rous, Esther, Elena, Patri y Pepi. 




\section{ÍNDICE}

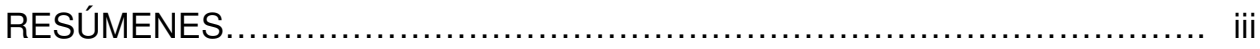

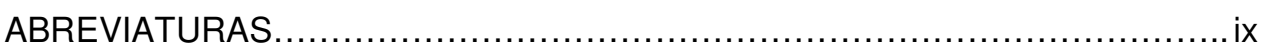

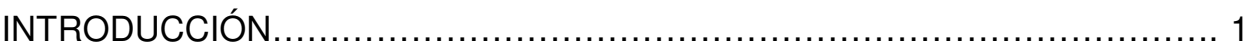

1- Interacción planta-patógeno.................................................. 3

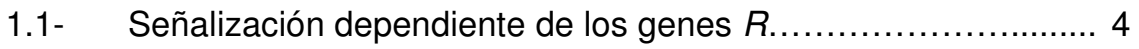

1.2- Respuestas defensivas locales................................ 5

1.3- Respuestas defensivas sistémicas .............................

1.4- Principales rutas de señalización defensiva....................... 8

2- CEVI1: gen inducible en interacciones víricas compatibles............. 9

3- Papel de las fosfatasas en procesos de señalización.....................10

4- Los virus como patógenos de plantas................................... 12

4.1- Generalidades del ciclo vital de los virus ........................ 13

Amplificación del genoma viral............................... 14

Infección sistémica de la planta.............................15

4.2- Estrategias descritas para generar resistencia a virus.............. 16

Resistencia derivada del patógeno....................... 16

Resistencia no derivada del patógeno..................... 18

Silenciamiento génico post-transcripcional.............. 18

Genes de resistencia................................ 19

Resistencia recesiva.................................... 22 
OBJETIVOS

RESULTADOS Y DISCUSIÓN

- Capítulo 1: A novel DNA-binding motif, hallmark of a new family of plant transcription factors

- Capítulo 2: 14-3-3 mediates transcriptional regulation by modulating nucleocytoplasmic shuttling of tobacco DNA-binding protein phosphatase-1

- Capítulo 3: Early molecular events determining susceptibility to potyvirus infection in Arabidopsis thaliana.

DISCUSIÓN GENERAL

CONCLUSIONES.

BIBLIOGRAFÍA. 81 


\section{RESUMEN}

El factor de transcripción DBP1 de Nicotiana tabacum, es el primer miembro de una nueva familia de reguladores transcripcionales que poseen, además de capacidad de unión al ADN, actividad proteín-fosfatasa de tipo $2 \mathrm{C}$. En este trabajo hemos abordado la caracterización funcional del factor regulador DBP1, determinando que su capacidad de unión al ADN reside en el motivo DNC, el cual se localiza en la región N-terminal de la proteína y está conservado entre las proteínas DBP de diferentes plantas mono y dicotiledóneas. Así mismo hemos llevado a cabo una búsqueda de factores proteicos que interaccionan con DBP1. Así, la isoforma G de la proteína 14-3-3 se presenta como el primer interactor de DBP1, comprometiendo en dicha interacción una zona del dominio N-terminal adyacente al motivo DNC. Mediante expresión transitoria en $N$. benthamiana hemos podido comprobar que la isoforma $G$ de la 14-3-3 es capaz de promover la exclusión nuclear de DBP1, modificando la distribución núcleocitoplasma que presenta en condiciones basales y participando así de manera indirecta en la regulación de genes diana de DBP1 como CEVI1.

De los cuatro homólogos estructurales de DBP1 identificados en A. thaliana, AtDBP1 es el representante estructuralmente más semejante a DBP1 de tabaco. AtDBP1 mantiene la capacidad de unirse al $\mathrm{ADN}$ así como la actividad fosfatasa $2 \mathrm{C}$ característica de esta familia, y es capaz de interaccionar a través de su región $\mathrm{N}$-terminal con la proteína GRF6, homóloga a la 14-3-3 G de tabaco. Con el objetivo de identificar dianas de AtDBP1 tanto a nivel transcripcional como post-transcripcional para así averiguar los procesos biológicos en los que están implicados estos factores, se ha realizado un análisis proteómico comparativo entre plantas Col-0 y mutantes atdbp 1 que ha puesto de manifiesto una baja acumulación de una de las isoformas del factor de inicio de la traducción $4 \mathrm{E}$, elF(iso)4E, en el mutante atdbp1. El menor nivel de acumulación de la proteína eIF(iso)E en la línea mutante atdbp1 parece obedecer a un control post-traduccional de AtDBP1 sobre elF(iso)4E. Esta hipótesis aparece reforzada por la existencia de una interacción directa entre ambas proteínas, que sugiere que elF(iso)4E podría ser sustrato de la actividad fosfatasa de AtDBP1.

Los factores elF(iso)4E y elF4E juegan un papel esencial en el ciclo vital de los potyvirus. La menor acumulación del factor elF(iso)4E en el mutante atdbp1 se traduce en un retraso en la acumulación y movimiento del potyvirus Plum pox virus (PPV) respecto a las plantas silvestres. Así, la pérdida de función de AtDBP1 parece desencadenar una resistencia parcial a varios miembros de la familia de los potyvirus. Por otra parte, hemos comprobado que la infección vírica promueve una mayor estabilización del factor elF(iso)4E. Además, tras la aplicación del inhibidor del proteosoma MG-132, observamos una mayor acumulación de eIF(iso)4E en plantas atdbp1, lo que sugiere que la forma fosforilada de este factor es más susceptible a la degradación vía proteosoma. De este modo, la capacidad de desfosforilación de AtDBP1 parece contribuir a la estabilización de elF(iso)4E. Los resultados obtenidos hasta 
el momento nos han permitido asignar un significado biológico a la actividad fosfatasa de AtDBP1, así como presentar a dicha fosfatasa como un nuevo componente de la resistencia recesiva frente a virus. 


\section{RESUM}

El factor de transcripció DBP1 de Nicotiana tabacum, és el primer membre d'una nova família de reguladors transcripcionals que posseixen, a més de capacitat d' unió al ADN, la funció de proteín-fosfatasa del tipus 2C. En aquest treball hem abordat la caracterització funcional del factor regulador DBP1, determinant que la seua capacitat d'unió al ADN resideix al motiu DNC, el qual es localitza en la regió $\mathrm{N}$-terminal de la proteïna i está conservat en els factors DBP de diferents plantes mono i dicotiledónees. Així mateix, hem dut a terme una recerca de factors proteics que interaccionen amb DBP1. Així, la isoforma $G$ de la proteïna 143-3 es presenta com el primer interactor de DBP1, comprometent en aquesta interacció una zona del domini $\mathrm{N}$-terminal adjacent al motiu DNC. Mitjançant l'expressió transitòria en $N$. benthamiana hem pogut comprovar que la isoforma $\mathrm{G}$ de la 14-3-3 és capaç de promoure l'exclusió nuclear de DBP1, modificant la distribució nucli-citoplasma que presenta en condicions basals i participant de manera indirecta en la regulació de gens diana de DBP1 com CEVI1.

Dels quatre homòlegs estructurals de DBP1 identificats en $A$. thaliana, AtDBP1 és el representant estructuralment més semblant a DBP1 de tabac. AtDBP1 manté la capacitat d'unirse al $\mathrm{ADN}$ així com l'actividad fosfatasa $2 \mathrm{C}$ característica d'aquesta família, i és capaç d'interaccionar a través de la seua regió N-terminal amb la proteïna GRF6, homòloga a la 14-3$3 \mathrm{G}$ de tabac. Amb l'objectiu d' identificar dianes d' AtDBP1 tant a nivell transcripcional com post-transcripcional per a esbrinar els processos biològics en els que estàn implicats aquests factors, s'ha realizat un anàlisi proteòmic comparatiu entre plantes Col-0 i mutants atdbp1 que ha posat de manifiest una baixa acumulació d'una de les isoformes del factor d'inici de la traducció $4 \mathrm{E}$, elF(iso)4E, en el mutant atdbp1. El menor nivell d' acumulació de la proteïna eIF(iso)E en la línea mutant atdbp1 pareix obeir a un control post-traduccional d'AtDBP1 sobre elF(iso)4E. Aquesta hipòtesi apareix reforçada per l'existència d'una interacció directa entre les dues proteínes, que sugereix que elF(iso)4E podría ser sustrat de l' activitat fosfatasa d'AtDBP1.

Els factors elF(iso)4E i elF4E juguen un paper essencial en el cicle vital dels potyvirus. La menor acumulació del factor elF(iso)4E en el mutant atdbp1 es tradueix en un retràs en l'acumulació i moviment del potyvirus Plum pox virus (PPV) respecte a les plantes silvestres. Així, la pèrdua de funció d' AtDBP1 pareix desencadenar una resistència parcial a diferents membres de la família dels potyvirus. Per altra banda, hem comprovat que la infecció vírica promou una major estabilització del factor elF(iso)4E. A més, després de I' aplicació de l' inhibidor del proteosoma MG-132, observem una major acumulació d' elF(iso)4E en plantes atdbp1, lo que sugereix que la forma fosforilada d' aquest factor és més susceptible a la degradació vía proteosoma. D' aquesta manera, la capacitat de desfosforilació d' AtDBP1 pareix contribuir a la estabilizació d'elF(iso)4E. Els resultats obtinguts fins ara ens han permet 
assignar un significat biològic a l' activitat fosfatasa d'AtDBP1, així com presentar a dita fosfatasa com un nou component de la resistència recessiva front a virus. 


\section{SUMMARY}

Nicotiana tabacum transcription factor DBP1 is the first representative of a novel family of transcriptional regulators that, besides exhibiting sequence-specific DNA-binding, also possess protein phosphatase activity of the $2 \mathrm{C}$ type. In this work we have accomplished the functional characterization of DBP1. DNA-binding ability resides in the $\mathrm{N}$-terminal region and involves a highly conserved domain that we have designated DNC motif. Using the yeast twohybrid system we have identified 14-3-3 isoform $G$ as the first interactor of a DBP factor. The interaction site lies in the $\mathrm{N}$-terminal region, close to the DNC motif. By means of transient expression assays in Nicotiana benthamiana we have shown that expression of 14-3-3 G promotes DBP1 nuclear exclusion, and that the modulation of DBP1 nucleo-cytoplasmic shuttling mediated by $14-3-3 \mathrm{G}$ is actually involved in the regulation of the expression of DBP1 target genes like CEVI1.

AtDBP1 is the closest structural homologue in the model species Arabidopsis thaliana among the four we have identified. AtDBP1 also binds DNA with the same sequence specificity as DBP1 and shows protein phosphatase activity in vitro. Moreover, it is able to interact with GRF6, a 14-3-3 G homologue, through the N-terminal region. With the aim of identifying both transcriptional and possible post-transcriptional AtDBP1 targets we performed a comparative proteomic analysis between wild-type Col-0 and atdbp1 loss-of-function mutant plants that resulted in the detection of lower accumulation levels in the atdbp1 mutant of a plant specific isoform of the translation intiation factor elF4E named eIF(iso)4E. The reduction in the amount of elF(iso)4E protein seems to obey to a post-trascriptional mechanism, and very likely occurrs post-translationally since we have demonstrated a direct protein-protein interaction between AtDBP1 and elF(iso)4E that suggests that the latter could be a substrate of AtDBP1 protein phosphatase activity.

elF(iso)4E and elF4E play a key role in the life cycle of potyvirus. The lower protein level of elF(iso)4E in the atdbp1 mutant hampers progression of the infection by the potyvirus PPV (Plum Pox Virus), resulting in a significant delay in viral accumulation and movement. Therefore, loss of AtDBP1 function leads to partial resistance against potyvirus. We have also shown that viral infection promotes stabilization of elF(iso)4E protein, and that application of the proteosome inhibitor MG-132 results in an increased accumulation of elF(iso)4E in atdbp1 mutant plants, suggesting that the phosphorylated form of elF(iso)4E is more susceptible to degradation via proteasome and that AtDBP1-mediated dephosphorylation might contribute to stabilization of elF(iso)4E. These results assign a biological role to the protein phosphatase activity of AtDBP1 and point to this regulatory factor as a novel component of recessive resistance mechanisms against potyvirus. 


\section{ABREVIATURAS}

3AT: 3-amino-triazol.

4E-BP: del inglés elF4E-binding protein.

A $_{600}$ : absorbancia a $600 \mathrm{~nm}$.

ABA: ácido abscísico.

ABI1: del inglés abscisic acid insensitive 1.

ABI2: del inglés abscisic acid insensitive 2 .

ACMV: del inglés African cassava mosaic virus.

ADN: ácido desoxirribonucleico.

ADNc: ADN copia.

ADN-T: ADN de transferencia.

ARN: ácido ribonucleico.

ARNi: ARN de interferencia.

ARNm: ARN mensajero.

ARNmi: micro-ARN.

ARNsi: ARN pequeño de interferencia.

Avr: gen de avirulencia.

BLOSUM: del inglés blocks substitution matrix.

BTH: S-metil éster del ácido-1, 2, 3-benzotiodiazol-7-carbotiótico.

CaMV: del inglés Cauliflower mosaic virus.

CC: del inglés coiled-coil.

CEVI1: del inglés citrus exocortis viroid-induced peroxidase 1.

Cdc25C: del inglés cell division cycle 25C.

cDNA: del inglés complementary DNA.

Cl: del inglés cytoplasmic inclusion.

CIYVV: del inglés Clover yellow vein virus.

CMV: del inglés Cucumber mosaic virus.

Col-0: ecotipo Columbia-0 de Arabidopsis thaliana.

CP: del inglés coat protein.

Ct: región carboxi-terminal.

CUM1: del inglés cucumovirus multiplication 1.

CUM2: del inglés cucumovirus multiplication 2.

DBP: del inglés DNA-binding protein phosphatase.

DCL: del inglés Dicer-like.

DMSO: dimetilsulfóxido.

DNA: del inglés desoxiribonucleic acid.

DNC: del inglés $D B P N$-terminal core.

DsPTP: Tirosín-fosfatasa de doble especificidad. 
DTH9: del inglés detachment 9.

EDTA: sal disódica del ácido etilén-diamino tetraacético.

eEF1a: del inglés eukaryotic elongation factor $1 a$.

elF4E: del inglés eukaryotic initiation factor $4 E$.

eIF(iso)4E: isoforma de elF4E.

EMSA: del inglés electrophoretic mobility shift assay.

ERK5: del inglés extracellular-signal-regulated kinase 5.

ET: etileno.

GA: del inglés giberellic acid.

GAL4AD: dominio de activación transcripcional del factor de levadura GAL4.

GAL4BD: dominio de unión a ADN del factor de levadura GAL4.

GFP: del inglés green fluorescent protein.

GRF6: del inglés G-box regulating factor 6 .

GUS: beta-glucuronidasa.

HA: del inglés hemaglutinin epitope.

HAB1: del inglés homology to $A B \mid 1 / A B I 2$.

Hc-Pro: del inglés helper component proteinase.

HIS3: imidazol-glicerol-fosfato deshidratasa.

Hog1: del inglés high osmolarity glycerol response 1.

Hot1: del inglés high-osmolarity-induced transcription 1.

HRT: del inglés hypersensitive response to TCV.

HR: del inglés hypersensitive response.

INA: ácido 2,6-dicloroisonicotínico.

IRES: del inglés internal ribosome entry site.
JA: del inglés jasmonic acid.
lacZ: gen beta-galactosidasa.
LMV: del inglés Lettuce mosaic virus.
LRP: del inglés leucine-rich protein.
LRR: del inglés leucine-rich repeat.

LSP1: del inglés loss of susceptibility to potyviruses 1.

LZ: del inglés leucine zipper.

MAMP: del inglés microbe-associated molecular pattern.

MAPK: del inglés mitogen-activated protein kinase.

MBP: del inglés maltose binding protein.

MEF2: del inglés myocyte enhancer-binding factor.

MES: ácido 2-(N-morpholino)etanosulfónico.

MG-132: carbobenzoxi-L-leucil-L-leucil-L-leucinal.

MP: del inglés movement protein.

MS: medio Murashige \& Skoog.

MYB: del inglés myeloblastosis oncogene. 
NADPH: nicotinamín-adenín dinucleótido fosfato reducido.

NahG: salicilato hidroxilasa.

NBS: del inglés nucleotide binding site.

Nla: del inglés nuclear inclusion a.

NLS: del inglés nuclear localization signal.

NO: óxido nítrico.

Nt: región amino-terminal.

P1: proteinasa 1.

PABP: del inglés poly $(A)$-binding protein.

PAMP: del inglés pathogen-associated molecular pattern.

PBS1: del inglés avrPphB susceptible 1.

PCR: del inglés polymerase chain reaction.

PDR: del inglés pathogen-derived resistance.

PEBV: del inglés Pea early browning virus.

PLRV: del inglés Potato leaf roll virus.

PP1: proteín fosfatasa de clase 1.

PP2A: proteín fosfatasa de clase $2 \mathrm{~A}$.

PP2B: proteín fosfatasa de clase 2B.

PP2C: proteín fosfatasa de clase 2C.

PPV: del inglés Plum pox virus.

PR: del inglés pathogenesis-related.

PSbMV: del inglés Pea seed-borne mosaic virus.

PTGS: del inglés post-transcriptional gene silencing.

Pto: del inglés Pseudomonas syringae pv. tomato resistance.

PTP: tirosín-fosfatasa.

Pv: patovar.

PVMV: del inglés Pepper veinal mottle virus.

PVX: del inglés Potato virus $X$.

PVY: del inglés Potato virus $Y$.

$\mathbf{R}:$ gen de resistencia.

RDR6: del inglés RNA-dependent RNA polymerase 6 .

RdRp: del inglés RNA-dependent RNA polymerase.

RGA: del inglés resistance gene analog.

RIN4: del inglés RPM1-interacting protein 4.

RLK: del inglés receptor-like kinase.

RNA: del inglés ribonucleic acid.

mRNA: del inglés messenger RNA.

ROS: del inglés reactive oxygen species.

RPS2: del inglés resistance to Pseudomonas syringae 2.

RPS5: del inglés resistance to Pseudomonas syringae 5. 
RT-PCR: del inglés reverse transcription-PCR.

qRT-PCR: del inglés quantitative RT-PCR.

RTM1: del inglés restricted TEV movement 1.

RTM2: del inglés restricted TEV movement 2.

SA: del inglés salicylic acid.

SAR: del inglés systemic acquired resistance.

SDS: dodecil sulfato sódico.

SIPK: del inglés salicylic acid-inducible protein kinase.

TBLASTN: del inglés translated basic local alignment search tool for nucleotide sequence databases.

T-DNA: del inglés transfer DNA.

TCV: del inglés Turnip crinkle virus.

TEV: del inglés Tobacco etch virus.

TIP: del inglés TCV-interacting protein.

TIR: del inglés Toll/interleukin receptor.

TMV: del inglés Tobacco mosaic virus.

TOM1: del inglés tobamovirus multiplication 1.

TOM2A: del inglés tobamovirus multiplication $2 A$.

ToMV: del inglés Tomato mosaic virus.

TSWV: del inglés Tomato spotted wilt virus

TuMV: del inglés Turnip Mosaic Virus.

TVMV: del inglés Tobacco vein mottling virus.

VPg: del inglés viral protein genome-linked.

VSM1: del inglés virus systemic movement 1.

WIPK: del inglés wound-inducible protein kinase. 
INTRODUCCIÓN 



\section{INTRODUCCIÓN}

Desde el comienzo de la civilización, las enfermedades de las plantas han desencadenado pérdidas importantes en muchos cultivos agrícolas. Una reducción del suelo asequible para la agricultura y el aumento demográfico han provocado el desarrollo de estrategias para proteger los cultivos y así mejorar la producción agrícola. Aunque los pesticidas han controlado satisfactoriamente algunas enfermedades, su uso creciente y continuado podría tener consecuencias perjudiciales para la salud y el medio ambiente. A su vez, el uso de variedades de cultivos de alto rendimiento también podría mejorar la productividad pero éstas serían más susceptibles a epidemias devastadoras por su uniformidad genética. Así, la aplicación de los mecanismos de defensa de la propia planta y el entendimiento de los procesos que subyacen a la enfermedad podrían conducirnos a una protección más eficiente contra los patógenos de las especies vegetales.

\section{1- Interacción planta-patógeno}

Las plantas son hospedadoras de muchas enfermedades infecciosas causadas por un amplio conjunto de patógenos, como bacterias, virus, hongos y nemátodos. Solo una proporción relativamente pequeña de estos agentes invade satisfactoriamente la planta hospedadora causando así la enfermedad. Es por ello que en el mundo vegetal la enfermedad constituye una excepción, y ello se debe a los múltiples mecanismos de defensa que las plantas poseen frente a estos patógenos. Algunos de estos mecanismos son constitutivos, estando establecidos en la planta antes de la llegada del patógeno; la pared celular o la cutícula son algunos ejemplos de barreras defensivas que forman parte de estos mecanismos, dificultando así la entrada de diferentes agentes invasores (Mauch-Mani \& Slusarenko, 1993; Hückelhoven, 2007). Otros mecanismos de defensa en la planta se inducen tras la percepción del patógeno y proporcionan protección no sólo en el sitio de infección sino también sistémicamente a lo largo de toda la planta (Shah et al., 1999). Esta respuesta inducible consta de dos niveles: el primero lo integran receptores específicos transmembrana que reconocen patrones moleculares asociados a microbios (MAMP, del inglés Microbe-asssociated molecular

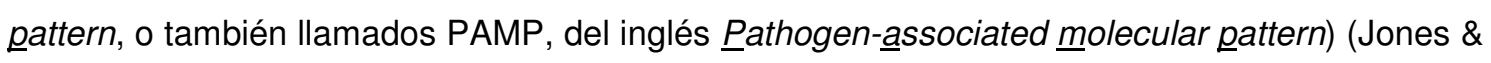
Dangl, 2006; Zipfel, 2008). Los MAMPs derivan de componentes conservados evolutivamente que resultan esenciales para el microbio, y su detección conlleva, a través de rutas específicas de señalización, la activación de los mecanismos de defensa de la planta. Estos mecanismos incluyen modificación de la pared celular, síntesis de especies reactivas de oxígeno y compuestos antimicrobianos y la inducción de un gran número de genes (Chisholm et al., 2006). En ocasiones los patógenos producen efectores específicos con objeto de evitar el reconocimiento de MAMPs por parte de este primer nivel de defensa de la planta (He et al., 2007). Sin embargo, un segundo nivel de protección, integrado por los genes de resistencia o 
genes $R$, permite reconocer los efectores producidos por el patógeno y activar de modo similar la respuesta defensiva.

\section{1- Señalización dependiente de los genes $R$}

Los genes de resistencia $(R)$ codifican productos capaces de responder a señales patogénicas, representadas por productos de genes de avirulencia (Avr), que culminan en respuestas de resistencia en la planta (Staskawicz et al., 1995; Rathjen \& Moffett, 2003; Bent \& Mackey, 2007). Para describir las interacciones entre las proteínas $R$ y las Avr, inicialmente fue propuesto por Flor (1971) el modelo "gen a gen". Según este modelo, cuando se produce el reconocimiento específico entre los productos de los genes de resistencia $R$ y los resultantes de la expresión de los genes de avirulencia Avr se activa una cascada de señalización que finalmente dará lugar a un colapso o muerte celular de aquellas células y tejidos situados en el sitio de inoculación, impidiéndose de este modo la propagación del agente infeccioso. Este mecanismo se manifiesta en forma de lesiones necróticas y se conoce como respuesta hipersensible o HR (Agrios, 2005; Mur et al., 2008). Por tanto, cuando se establece un reconocimiento específico "gen a gen" entre ambas proteínas, la enfermedad no tiene lugar, siendo la planta resistente y el patógeno avirulento. Esto se conoce como una interacción planta-patógeno incompatible, que se caracteriza por el establecimiento de una infección patogénica inicial que no logra progresar debido a que la planta reacciona restringiendo la dispersión del patógeno. En el caso de que no se produzca interacción entre un alelo $R$ y un Avr, se desencadena una interacción compatible, en la que el patógeno puede multiplicarse y progresar sistémicamente, invadiendo otros tejidos y provocando así la enfermedad. En este escenario, la planta será susceptible y el patógeno virulento (Keen, 1990; van Kan et al., 1992; Király et al., 2007). Por tanto podemos decir que los genes $R$ codifican productos que presentan dos funciones, actúan como sensores de los correspondientes factores Avr e inician cascadas de señalización para la expresión de genes relacionados con defensa.

Van der Biezen \& Jones propusieron un modelo más sofisticado para las interacciones R-Avr. La "hipótesis del guardián" postula que las proteínas R (guardián) están constitutivamente asociadas con proteínas celulares del hospedador que son requeridas por el patógeno para la infección. Durante la infección, el patógeno causa modificaciones en dichas proteínas del hospedador que son detectadas por las proteínas "guardián" para iniciar una cascada de señalización que culmina en una respuesta de resistencia (Van der Biezen \& Jones, 1998; Van der Hoorn, 2002). Las proteínas RPS2 y RPS5 de Arabidopsis thaliana representan un claro ejemplo de esta hipótesis. Estas proteínas $\mathrm{R}$ reconocen indirectamente a los efectores AvrRpt2 y HopAR1 de $P$. syringae, que tienen como dianas componentes importantes en la señalización defensiva como son RIN4 y PBS1. La degradación de RIN4 y PBS1 inducida por el patógeno es detectada por los guardianes RPS2 y RPS5, desencadenándose así una respuesta defensiva en la planta (Ade et al., 2007; Axtell \& Staskawicz, 2003; Day et al., 2005; Mackey et al., 2003). En los sistemas virales el par HRT-TCV da soporte a dicha hipótesis, siendo la 
proteína de cubierta del Turnip crinkle virus (TCV) el determinante de avirulencia que desencadenará la resistencia mediada por el gen $H R T$ al interaccionar con un factor de transcripción TIP (ICV-ịnteracting protein) del hospedador (Ren et al., 2000).

Según este modelo, una misma proteína $R$ podría reconocer la presencia de múltiples proteínas Avr a través de una única o varias proteínas del hospedador. Esto podría explicar la escasa presencia de genes $R$ en el genoma de A.thaliana (Meyers et al., 2003) y la divergencia funcional de proteínas $\mathrm{R}$ estructuralmente similares.

La clonación de numerosos genes de resistencia procedentes de diversas especies vegetales ha revelado la existencia de un número limitado de motivos estructurales, lo que sugiere que tanto el reconocimiento específico del patógeno por las proteínas $\mathrm{R}$ como los procesos subsiguientes podrían estar mecanísticamente conservados. Las características estructurales mayoritariamente representadas en los productos de los genes $R$ incluyen repeticiones ricas en leucina (LRR) de longitud variable en su dominio C-terminal y un sitio de unión a nucleótidos (NBS) localizado en la región central (Hammond-Kosac \& Parker, 2003; McHale et al., 2006). Se cree que el dominio LRR estaría involucrado en interacciones proteína-proteína mientras que el dominio NBS estaría más directamente relacionado con señalización.

El conocimiento de los mecanismos que subyacen a la regulación de la respuesta defensiva de la planta ha permitido el diseño de nuevas estrategias encaminadas a la obtención de variedades resistentes, promoviendo la activación de la señalización defensiva mediante el empleo de genes $R$ o genes reguladores (Campbell et al., 2002; Collinge et al., 2008). Los efectos deletéreos que la expresión constitutiva de este tipo de genes suele tener para la planta podrían evitarse utilizando promotores selectivos que limiten la expresión del transgén (Gurr \& Rushton, 2005).

\section{2- Respuestas defensivas locales}

Tras el reconocimiento del patógeno, la planta es capaz de responder ante dicho agente activando una cascada de señalización que finalmente dará lugar al colapso o muerte de aquellas células y tejidos situados en el sitio de infección. Este mecanismo se conoce como respuesta hipersensible o HR. Esta reacción local, mediante una muerte celular programada en el sitio de la infección, permite limitar el movimiento del patógeno a corta y larga distancia (Staskawicz et al., 1995; Heath, 2000; Shirasu \& Schulze-Lefert, 2003).

Las respuestas más tempranas del hospedador incluyen cambios en el flujo de iones, activación de vías de señalización protagonizadas especialmente por protein quinasas, alteración de perfiles transcripcionales, generación de especies reactivas del oxígeno (ROS) y producción de óxido nítrico (NO). Estos cambios inmediatos son posteriormente seguidos por 
una alteración de actividades celulares que desembocarán en una muerte celular programada de las células infectadas (respuesta HR).

Se ha propuesto que los cambios en el flujo de iones activan cascadas de proteínquinasas que son importantes para la transducción de señales durante la defensa (Nakagami et al., 2005; Pedley \& Martin, 2005). Se ha descrito la activación en defensa de una proteínquinasa inducida por herida (WIPK) y otra inducida por salicílico, una de las moléculas señalizadoras clásicas de defensa (SIPK) (Zhang \& Klessig, 2001), las cuales a su vez inducen la expresión de genes relacionados con defensa, como varios factores de transcripción de la familia específica de plantas WRKY y factores de transcripción tipo MYB (Kim \& Zhang, 2004). Existen numerosas evidencias que indican que tanto las proteín-quinasas como las proteínfosfatasas desempeñan un papel esencial, no sólo en los primeros instantes del reconocimiento entre el huésped y el patógeno, sino también en los eventos posteriores que tienen lugar durante la cascada de señalización, los cuales conducirán a la activación de la respuesta defensiva de la planta (Yang et al., 1997). El aislamiento y caracterización del gen Pto de tomate, el cual codifica una serín-treonín quinasa (Martin et al., 1993; Martin, 1999), y de Xa21 de arroz, que codifica un receptor transmembrana rico en leucina y con un dominio quinasa (Song et al., 1995), así como los experimentos farmacológicos realizados con inhibidores de la fosforilación de proteínas, también avalan el papel que juegan estas modificaciones covalentes post-traduccionales en la activación de los mecanismos de respuesta temprana (Ligterink et al., 1997; Scheel, 1998; Zhang \& Klessig, 1998; Romeis et al., 1999).

El reconocimiento de un patógeno potencial da lugar asimismo a una alteración del metabolismo que conlleva la sobreproducción y acumulación de especies reactivas de oxígeno (ROS) (Shetty et al., 2008). Las ROS son consideradas como moléculas señalizadoras de la respuesta defensiva de las plantas ante el ataque de patógenos (Torres et al., 2006). A dicho fenómeno se le conoce con el nombre de explosión oxidativa (oxidative burst) (Tenhaken et al., 1995; Doke et al., 1996; Lamb \& Dixon, 1997; Xing et al., 1997) y se inicia con la activación del complejo NADPH oxidasa, que genera la aparición transitoria de especies reactivas de oxígeno tales como el radical superóxido $\left(\mathrm{O}_{2}{ }^{-}\right)$y el peróxido de hidrógeno $\left(\mathrm{H}_{2} \mathrm{O}_{2}\right)$. La explosión oxidativa acontece en dos fases dependiendo del tipo de interacción patogénica. De este modo, se produce una primera acumulación de ROS de menor magnitud, que ocurre a los pocos minutos, y de manera independiente del tipo de interacción, ya sea ésta compatible o incompatible, no afectando a la viabilidad celular. Una segunda explosión oxidativa de mayor magnitud acontece sólo en las interacciones incompatibles tras varias horas de la infección patogénica, siendo crítica para el establecimiento de la resistencia y la activación de una respuesta hipersensible.

El incremento en los niveles de acumulación de ROS parece estar asociado a varios de los procesos que acompañan a la respuesta defensiva. Existen numerosos estudios en los cuales 
se ha descrito que el $\mathrm{H}_{2} \mathrm{O}_{2}$ podría estar implicado en el refuerzo de la pared celular, contribuyendo al entrecruzamiento mediado por peroxidasas de ciertos componentes de dicha estructura celular. Estas modificaciones hacen que la pared se vuelva más refractaria a la digestión por enzimas líticos microbianos y sirva para frenar la entrada del patógeno. Asimismo, la posterior síntesis y secreción de nuevos polímeros tales como callosa, lignina y proteínas de pared, como glicoproteínas ricas en prolina, favorece la formación de nuevos entrecruzamientos con los elementos preexistentes, dando lugar a un refuerzo adicional de la pared (Hammond-Kosack \& Jones, 1996; Kawano, 2003). Por otra parte, las ROS están implicadas en la señalización de diferentes respuestas defensivas, como la activación de HR o la acumulación de fitoalexinas, mediante la activación de cascadas de fosforilación o directamente regulando la expresión de ciertos genes (Shetty et al., 2008).

El óxido nítrico (NO) también participa en la activación del proceso de muerte celular asociado a la HR (Romero-Puertas et al., 2004; Zeier et al., 2004; Hong et al., 2008; Wilson et al., 2008). Se ha demostrado que el NO tiene la capacidad de potenciar la muerte celular producida por el incremento de los niveles de ROS, debido a que se une a los grupos hemo de ciertas proteínas como catalasas y ascorbato peroxidasas inhibiendo de esta forma su actividad destoxificadora de $\mathrm{H}_{2} \mathrm{O}_{2}$ (Clark et al., 2000).

\section{3- Respuestas defensivas sistémicas}

La respuesta hipersensible que acontece en el lugar de entrada del patógeno desencadena, en la mayoría de los casos, la aparición posterior de una resistencia sistémica no específica o resistencia sistémica adquirida (SAR) a lo largo de toda la planta (Grant \& Lamb, 2006). Esta protección, de larga duración, se produce en tejidos distales a los puntos de infección inicial y es funcional frente a posibles infecciones secundarias causadas por un amplio espectro de patógenos (Ryals et al., 1996; Delaney, 2000). La SAR se caracteriza por la acumulación de la molécula señalizadora ácido salicílico (SA) y por la activación selectiva y coordinada de la expresión de un grupo característico de genes de defensa (genes $S A R$ ), que estarán directamente implicados en el establecimiento y mantenimiento de dicha resistencia (Dong, 1998; Glazebrook, 1999; Glazebrook, 2001; Durrant \& Dong, 2004; Loake \& Grant, 2007).

El conjunto mayoritario de proteínas defensivas sintetizadas en las plantas durante dicha respuesta SAR pertenece a la familia de las proteínas PR (proteínas relacionadas con la patogénesis). Cabe destacar que sólo los genes que codifican proteínas PR ácidas ( $P R-1, P R$ 2, $P R-5$ ) responden fuertemente al SA o cualquiera de sus análogos, y se expresan tanto local como sistémicamente después de una infección. Por el contrario, los genes que codifican las isoformas básicas se inducen localmente alrededor de la HR, indicándonos que dichas proteínas PR básicas no estarían implicadas en la respuesta SAR (Brederode et al., 1991). 
La presencia del SA en los tejidos distales de la planta es necesaria para que se establezca la cascada de señalización que da lugar a la activación de dicha respuesta y a la expresión de genes SAR (Vernooij et al., 1994). Evidencia de ello es que la adición exógena de SA tanto en hojas de plantas de tabaco como de Arabidopsis thaliana induce la expresión de genes SAR y una mayor resistencia de las plantas a patógenos (Malamy et al., 1990; Uknes et al, 1993; Ward et al., 1991). Además, en plantas transgénicas NahG, las cuales no pueden acumular SA debido a la sobreexpresión del gen salicilato hidroxilasa (NahG), que degrada el SA a catecol (Delaney et al., 1994; Vernooji et al., 1994), no se induce la respuesta SAR (Gaffney et al., 1993), presentando una marcada susceptibilidad a patógenos fúngicos, bacterianos y virales (Delaney et al., 1994). Todo ello indica que el SA es esencial para el establecimiento de la respuesta SAR en las plantas. A su vez, la identificación de dos compuestos sintéticos análogos al SA, el ácido 2,6-dicloroisonicotínico "INA" (Métraux et al., 1991; Ward et al., 1991) y el S-metil éster del ácido-1, 2, 3-benzotiodiazol-7-carbotiótico "BTH" (Görlach et al., 1996), que también promueven SAR, refuerza el papel que juega el SA en la inducción de esta respuesta. Sin embargo, parecen existir componentes adicionales independientes del SA en la señalización de SAR, como pone de manifiesto la identificación del mutante dth9 de Arabidopsis thaliana. Este mutante no es capaz de ejecutar una respuesta SAR efectiva, si bien no tiene mermadas ni la acumulación de SA ni la inducción de genes PR (Mayda et al., 2000b). La inducción de resistencia en partes de la planta distales al sitio de inoculación inicial sugiere la existencia de una señal que se desplazaría sistémicamente dando lugar al establecimiento de SAR (Bi et al., 1995). Inicialmente se propuso al SA como dicha señal. Sin embargo, ciertos experimentos han demostrado que el SA no representa dicha señal sistémica independientemente de que su presencia en tejidos distales es absolutamente necesaria para la implantación de SAR (Vernooij et al., 1994).

\section{4- Principales rutas de señalización defensiva.}

El estudio de los genes que controlan la respuesta defensiva en Arabidopsis thaliana ha permitido establecer la existencia de dos rutas de señalización, una dependiente del ácido salicílico (SA) y otra independiente del SA pero dependiente del ácido jasmónico (JA) y etileno (ET). Las hormonas SA, JA y ET son las moléculas señal clave que median la expresión de respuestas defensivas en plantas. La activación de la ruta dependiente del SA actúa confiriendo protección a las plantas frente a patógenos biotrofos, tales como especies del género Pseudomonas e Hyaloperonospora. Mientras que la señalización regulada por JA/ET está involucrada preferentemente en la defensa frente a patógenos necrotrofos tales como Botrytis y Erwinia (Spoel et al., 2007). Estas dos rutas no son independientes, sino que una influye sobre la otra formando parte de una red de señalización muy compleja que determina la respuesta defensiva frente a un patógeno específico (Pieterse \& van Loon, 1999; Feys \& Parker, 2000; Glazebrook, 2001; Kunkel \& Brooks, 2002; Thomma et al., 2001; Koornneef \& Pieterse, 2008). Otras hormonas afectan también a la señalización defensiva, y ello es aprovechado por algunos patógenos para interferir con los mecanismos de defensa de la planta 
y promover virulencia; así, la infección por Pseudomonas syringae induce la acumulación de ácido abscísico (ABA), el cual inhibe a su vez la acumulación de SA y la expresión de genes de resistencia basal (de Torres-Zabala et al., 2007). De manera similar, el tratamiento con auxinas sintéticas reprime la expresión génica inducida por SA, y este, a su vez, reprime la señalización dependiente de auxinas (Wang et al., 2007).

\section{CEVI1: gen inducible en interacciones víricas compatibles}

El estudio de los mecanismos moleculares responsables de la regulación de genes de defensa constituye una valiosa herramienta para la identificación de componentes implicados en las rutas de transducción de señal en interacciones planta-patógeno. Con el propósito de buscar factores del hospedador implicados en la respuesta patogénica se identificó en tomate el gen CEVI1 (citrus exocortis viroid-induced peroxidase 1), el cual codifica una peroxidasa aniónica de función desconocida (Vera et al., 1993). Dicha peroxidasa se induce en interacciones compatibles con patógenos virales, como el Tomato mosaic virus (ToMV), pero no frente a infecciones protagonizadas por otros patógenos biotrofos, ni en interacciones compatibles ( $P$. syringae pv. tomato) ni en incompatibles ( $P$. syringae pv. syringae). En cuanto a su patrón de expresión, CEVI1 no es capaz de responder a tratamientos con las moléculas señalizadoras clásicas de defensa como el SA, ET o JA, ni a estímulos de herida (Mayda et al., 2000a). Todos estos datos sugieren que la expresión del gen CEVI1 parece responder a una nueva vía de señalización de defensa en plantas.

Con el objetivo de conocer el mecanismo molecular que subyace al control transcripcional del gen CEVI1, se llevó a cabo un análisis funcional de su promotor mediante ensayos de expresión en plantas transgénicas de tabaco del gen marcador GUS (que codifica la $\beta$-glucuronidasa) bajo el control de diferentes regiones del promotor del gen CEVI1. Estos estudios permitieron definir un promotor mínimo responsable de la regulación transcripcional del gen, que se denominó 3a4, identificándose en el mismo como elementos cis una caja invertida GCC mediadora de la expresión inducible por etileno de genes relacionados con la patogénesis y un elemento TGTCTC que otorga inducibilidad por auxinas. Posteriormente, se identificó un complejo proteico que reconocía específicamente la secuencia 3a4 en condiciones en las que el gen CEVI1 no se expresa. La pérdida de la interacción de dicho complejo con el fragmento 3a4 tras la aplicación de estímulos que promueven la inducción del gen, sugería que dicho complejo actuaría como un mecanismo de represión de la expresión de CEVI1 (Carrasco et al., 2003).

El rastreo por Southwestern de una genoteca de ADNc de tabaco usando el fragmento 3a4 como sonda llevó al aislamiento de una proteína capaz de reconocer de forma específica dicha secuencia. La proteína identificada además de capacidad de unión al ADN, presentaba actividad proteín-fosfatasa, por lo que se denominó a la misma DBP1 (ㅁNA-binding protein 
phosphatase 1). Ambas actividades bioquímicas fueron demostradas utilizando proteína recombinante expresada y purificada en E. coli (Carrasco et al., 2003).

El aislamiento de DBP1 en tabaco (Nicotiana tabacum) ha puesto de manifiesto la existencia de un nuevo factor de transcripción en plantas no descrito hasta la fecha, caracterizado por presentar una doble funcionalidad que se refleja a nivel estructural: DBP1 posee un dominio $\mathrm{N}$-terminal implicado en la interacción con el ADN que no presenta similitud de secuencia con proteínas conocidas, y un dominio C-terminal en el que reside la actividad proteín-fosfatasa.

\section{Papel de las fosfatasas en procesos de señalización}

Las proteín-fosfatasas están presentes en todos los organismos eucarióticos y representan uno de los mayores grupos funcionales de proteínas. Estas enzimas regulan vías metabólicas y están estrechamente implicados en la gran mayoría de procesos de señalización celular. La fosforilación reversible de proteínas, mediada por la acción coordinada de proteínquinasas y proteín-fosfatasas, es un importante mecanismo de transducción de señal que permite regular muchos procesos biológicos. Es una modificación postranscripcional de la proteína capaz de alterar su comportamiento, modificando así su actividad biológica intrínseca, su localización subcelular, su vida media o su interacción con otras proteínas. Por tanto, es un proceso crucial en la integración de señales dentro de la célula y puede ser importante para la extensión y duración de una respuesta.

En Arabidopsis thaliana, tanto fosfatasas como quinasas se presentan en grandes familias de proteínas; existen más de 1000 genes (Wang et al., 2003) que codifican proteínquinasas y otros 112 (Kerk et al., 2002) que codifican subunidades catalíticas de proteínfosfatasas. En base a la especificidad del sustrato aminoacídico, las fosfatasas se dividen en dos grandes grupos:

1- Tirosín fosfatasas (PTPs): pueden ser específicas de residuos tirosina o mostrar especificidad dual (DsPTP), desfosforilando en este caso tanto fosfotirosinas como fosfoserinas/fosfotreoninas. En Arabidopsis thaliana se conocen 18 PTPs (Kerk et al, 2002) y han sido implicadas en respuestas de señalización mediada por ABA (abscisic acid) y auxinas.

2- Serín/treonín fosfatasas: como su nombre indica son capaces de desfosforilar residuos fosforilados de serina o treonina, y se dividen en dos familias. La familia PPP engloba las fosfatasas de tipo1 (PP1), las de tipo 2A (PP2A) y las de tipo 2B (PP2B). Y las fosfatasas de tipo $2 \mathrm{C}$ (PP2C) y otras fosfatasas serín/treonín dependientes de magnesio definen a la familia PPM (Wang et al., 2003). 
Las fosfatasas $2 \mathrm{C}$ son enzimas monoméricos que existen en todos los eucariotas, cuya actividad catalítica requiere de cationes divalentes de $\mathrm{Mn}^{2+} \circ \mathrm{Mg}^{2+}$ (Shenolikar, 1994; Wera \& Hemmings, 1995). Aunque las PP2C no muestran una aparente homología de secuencia aminoacídica con otros tipos de fosfatasas de la familia PPP, la similitud en la estructura tridimensional sugiere un mecanismo catalítico similar a estas proteínas (Das et al., 1996). En el genoma de Arabidopsis hay alrededor de 69 PP2C, las cuales son mucho más abundantes que en otros organismos eucariotas (Kerk et al., 2002). Se postula que su actividad fosfatasa podría estar regulada por la expresión de la proteína, compartimentalización, secuestro o proteolisis. Muchas PP2C de plantas poseen un dominio catalítico conservado pero presentan extensiones $\mathrm{N}$-terminales altamente divergentes que pueden contribuir a la regulación de la especificidad de sustrato y localización subcelular (Schweighofer et al., 2004). Originariamente se consideraba que las fosfatasas actuaban simplemente para revertir los efectos de las quinasas, pero en los últimos años se ha hecho evidente que dichas proteínas desempeñan funciones reguladoras esenciales y están implicadas en la regulación de diversas vías de señalización, tales como vías de respuesta a estrés y desarrollo, actuando en muchos casos como reguladores negativos de las mismas (Wang et al., 2003).

En situaciones de estrés las PP2C cooperan con otras fosfatasas, tales como PTPs, DsPTPs y PP2As en la desfosforilación de componentes clave de cascadas de transducción de

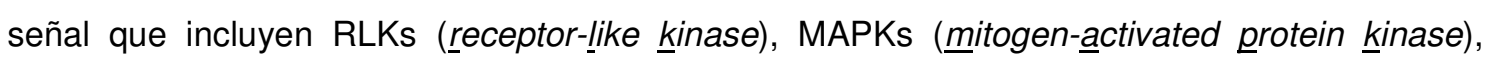
quinasas de MAPKs (MAPKKs) y quinasas de MAPKKs (Schweighofer et al., 2004). Un ejemplo de ello es el caso de la PP2C de alfalfa, MP2C, la cual está implicada en la regulación negativa de una de las vías de MAPK activada por herida (Meskiene et al., 1998).

Estudios de respuesta a estrés ambiental y frente a patógenos han revelado la importancia de los procesos de fosforilación y desfosforilación en las vías de señalización desencadenadas por elicitores patogénicos y señales de estrés abióticas. La fosforilación reversible juega un importante papel en la activación e inactivación de MAP quinasas en los primeros estadíos de estas vías (Mizoguchi et al., 1997). En interacciones patogénicas se cree que las proteín- quinasas pueden desencadenar la respuesta defensiva y que las fosfatasas PP1 y/o PP2A podrían ser las responsables de prevenir que esa respuesta se muestre constitutiva en condiciones normales o de reposo (Mackintosh et al., 1994; Chandra \& Low, 1995). Se ha demostrado un incremento de la actividad MAPK frente a elicitores patogénicos (Ligterink et al., 1997) y moléculas señalizadoras de defensa como el SA (Zhang \& Klessig, 1997). Esta activación de las MAPK, mediante fosforilación de residuos de treonina y tirosina, es transitoria debido a la desfosforilación mediada por fosfatasas específicas.

En cuanto a señalización hormonal, en Arabidopsis existen varias serín/treonín fosfatasas implicadas en la regulación de la vía de señalización dependiente del ABA como

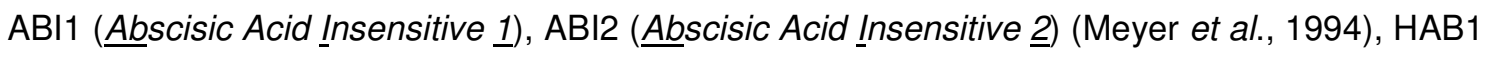


( de los mutantes abi1 y abi2, estudios de expresión transitoria y análisis de plantas transgénicas antisentido demostraron que estas PP2Cs actúan como reguladores negativos de la señalización por ABA (Sheen, 1998; Merlot et al., 2001; Gosti et al., 1999).

También se ha demostrado que la proteín fosfatasa KAPP de Arabidopsis interacciona con CLAVATA1, una quinasa tipo receptor implicada en el desarrollo de los meristemos vegetativos y florales (Clark et al., 1997).

Aunque muchas PP2C han sido caracterizadas a nivel molecular, mucho menos se sabe acerca de su función in vivo. De ahí que uno de los principales retos sea descubrir la importancia funcional de estos enzimas. Para ello, serán importantes estudios basados en análisis de mutantes de inserción de ADN-T y de ARNi en combinación con perfiles de expresión génica mediante microarrays y proteómica, así como determinar la localización subcelular de estas PP2C in vivo en las células de la planta. A pesar de conocer algunas de las implicaciones de PP2C en vías de señalización, en muchos casos se desconoce cuáles son sus dianas. Por tanto, uno de las claves para conocer la función de PP2C será identificar sus sustratos. Una combinación de aproximaciones de biología celular, molecular, bioquímica y genética constituirá la mejor estrategia para un análisis funcional de las PP2C.

\section{Los virus como patógenos de plantas}

Los virus de plantas se consideran la mayor amenaza para la agricultura moderna, provocando deterioros en la planta, bajas en la productividad y productos imperfectos o de baja calidad en muchos cultivos y plantas ornamentales de todo el mundo. Dado el carácter generalizado y persistente de las enfermedades provocadas por estos patógenos, se hace necesario establecer métodos de control adecuados para prevenir infecciones, proteger los cultivos y minimizar así las pérdidas agrarias. El desarrollo de estrategias para controlar y/o eliminar las enfermedades víricas en plantas requiere del conocimiento de las características moleculares de los virus, las funciones de las proteínas expresadas por su genoma, sus interacciones con los hospedadores y los diferentes mecanismos mediante los cuales estos patógenos se adaptan a diferentes hospedadores.

Los virus que provocan enfermedades en el reino vegetal se clasifican en virus de ARN y virus de ADN según la naturaleza de su material genético, siendo los de ARN de cadena sencilla y polaridad positiva los más frecuentes (Hull, 2002). El género Potyvirus constituye uno de los grupos más importantes de virus capaces de infectar plantas (Shukla et al., 1994; Fauquet \& Mayo, 1999), representando más del 30\% de todos los virus de plantas conocidos. Generalmente, estos virus son transmitidos por áfidos (Shukla et al., 1994), aunque alguno de ellos, a su vez, se puede propagar a través de las semillas de algunos de sus hospedadores 
(Johansen et al., 1994). Este género pertenece a la familia Potyviridae, que junto con las familias Picornaviridae, Sequiviridae, Comoviridae y Caliciviridae pertenecen al grupo de virus de ARN de cadena sencilla y polaridad positiva; y se divide en los géneros de Potyvirus, Macluravirus, Bymovirus, Rymovirus, Tritimovirus e Ipomovirus (van Regenmortel et al., 2000). Los potyvirus predominantemente afectan cultivos de la familia de las solanáceas. Algunas de las especies de estas plantas, como patata (Solanum tuberosum), tomate (Solanum lycopersicum) o pimiento (Capsicum spp) tienen una gran importancia económica a nivel mundial; es por ello que el estudio de los potyvirus que infectan estos cultivos es de gran relevancia para poder minimizar las pérdidas económicas desencadenadas por estas infecciones.

La naturaleza y extensión de los síntomas para un hospedador específico dependen de la cepa del virus y de las condiciones ambientales que probablemente influyan en el desarrollo y fisiología del hospedador. Los síntomas son el resultado de las interacciones complejas que se dan entre el hospedador y el virus a nivel celular. Los efectos sintomáticos pueden ser la consecuencia de la desviación de los recursos de la planta para la síntesis de proteínas y ácidos nucleicos específicos del virus, o de los efectos que puedan desencadenar los productos víricos en los procesos celulares normales. Generalmente, para una interacción compatible entre hospedador y virus, la severidad de los síntomas reflejará el nivel de replicación y acumulación vírica. Diferentes estudios demuestran que varias regiones del genoma potyviral podrían estar implicadas en la sintomatología, pero dependiendo de la combinación específica entre virus y hospedador se requieren unas proteínas virales u otras. Así, en el caso de los potyvirus, no ha sido posible identificar ningún principio o norma unificadora que explique la formación de los síntomas (Revers et al., 1999).

\section{1- Generalidades del ciclo vital de los virus}

Los virus son parásitos intracelulares obligados no siendo funcionalmente activos fuera de sus células hospedadoras. Como todas las entidades biológicas, poseen un genoma que contiene la información genética necesaria para su propia multiplicación en las células hospedadoras y para adaptarse a cambios ambientales. Se definen como entidades cuyo genoma, ya sea $A D N$ o $A R N$, se reproduce dentro de las células vivas usando la maquinaria de las mismas para así dirigir la síntesis de partículas especializadas, conocidas como viriones, que serán capaces de transferir el genoma viral a otras células.

El ciclo infectivo de un virus empieza cuando el virus entra en la célula a través de heridas causadas por daños físicos debidos al medio ambiente, o por la acción de vectores como insectos, ácaros, nemátodos y ciertos hongos habitantes del suelo. En el citoplasma, el virus de ARN se desensambla, replica, traduce sus mensajeros a proteínas y se moviliza local y sistémicamente (Stange, 2006). Para poder completar su ciclo vital, el virus utiliza energía y 
proteínas de la célula hospedadora normalmente implicadas en actividades específicas del hospedador. De este modo, durante cada etapa de este ciclo se generan complejas interacciones entre la planta hospedadora y el virus que están siendo objeto de intenso estudio en los últimos años.

\section{Amplificación del genoma viral}

Tanto para virus de ARN como de ADN, la acumulación viral en la célula vegetal depende de los procesos de replicación y traducción del genoma viral (Buck, 1999; Ahlquist et al., 2003; Noueiry \& Ahlquist, 2003; Hanley-Bowdoin et al., 2004; Ishikawa \& Okada, 2004).

El genoma potyviral consiste en una molécula simple de ARN de polaridad positiva de aproximadamente 10 kilobases que presenta en su extremo 3' una cola poli(A) (Hari et al., 1979) y unida covalentemente a su extremo 5' una proteína conocida como VPg (Siaw et al., 1985; Riechmann et al., 1989; Murphy et al., 1990). Esta molécula de ARN codifica una gran poliproteína que se procesa postraduccionalmente por tres proteasas virales conocidas con el nombre de Nla-Pro (Carrington \& Dougherty, 1987; Hellmann et al., 1988; Garcia et al., 1989; Ghabrial et al., 1990), Hc-Pro (Carrington et al., 1989) y P1 (Verchot et al., 1991). Como resultado de esta fase proteolítica, se generan diez proteínas maduras de funciones conocidas (Urcuqui-Inchima et al., 2001). Hasta la fecha sólo se conocía la existencia de un único marco de lectura abierto pero recientemente se ha descubierto una secuencia codificante nueva en la familia Potyviridae dentro del cistrón P3 del ARN genómico viral (Chung et al., 2008).

La amplificación del genoma de los potyvirus requiere dos procesos fundamentales: la replicación del ARN viral y una traducción del mismo para la síntesis de las proteínas específicas del virus. La interrelación de estos dos procesos, presumiblemente integrados espacial y temporalmente, hace difícil asignar a diferentes proteínas del virus funciones específicas únicamente en el proceso de replicación o en la traducción.

Los potyvirus, como virus de ARN de hebra simple y polaridad positiva, se replican a través de una molécula de ARN negativa complementaria a su genoma, la cual se genera por la polimerasa de ARN dependiente de ARN (RdRp) codificada por el propio virus. Esta cadena negativa se usará para la síntesis de posteriores moléculas de ARN de polaridad positiva, produciéndose así múltiples copias del genoma viral. Esta etapa de replicación viral ocurre en asociación con las membranas celulares (Schaad et al., 1997; Bienz, 1992). Además de la RdRp, varias proteínas virales están implicadas en este proceso, tales como la actividad helicasa de la proteína Cl (Laín et al., 1990), la función replicativa de la proteína Nla (Schaad et al., 1996) y la proteína 6K2 (Restrepo-Hartwig \& Carrington, 1994; Schaad et al., 1997). El ARN viral de los potyvirus, a pesar de no poseer la estructura CAP en su extremo 5' como los ARN mensajeros del hospedador, interacciona con factores de inicio de la traducción (Wittman et al., 1997; Schaad et al., 2000) que permiten su circularización. A pesar de las diferencias 
estructurales, la conservación de esta característica permite a los virus tener acceso a la maquinaria de traducción del hospedador, desencadenando así la traducción eficiente de sus proteínas (Le et al., 1997; Wei et al., 1998; Borman et al., 2000).

El ARN potyviral es traducido por los ribosomas del hospedador, pero a diferencia de los ARNs mensajeros celulares, este ARN no presenta una típica estructura CAP en su extremo 5', sino que dicha estructura es sustituida por una proteína codificada por el propio virus denominada VPg, la cual se une covalentemente a este extremo. Existen estudios que indican que la proteína VPg podría participar en el inicio de la traducción del ARN viral, ya que se ha demostrado la interacción entre las VPg de los potyvirus Turnip mosaic virus (TuMV) y Tobacco etch virus (TEV) con el factor de inicio de la traducción elF(iso)4E de A. thaliana (Wittmann et al., 1997; Lellis et al., 2002).

\section{Infección sistémica de la planta}

La infección sistémica de una planta ocurre cuando el virus es capaz de moverse, después de la etapa de amplificación del genoma, desde el foco de infección primario para invadir regiones distales del hospedador (Lucas \& Gilbertson 1994; Carrington et al. 1996). Inicialmente el virus experimenta un movimiento célula a célula, moviéndose entre células contiguas a través de los plasmodesmos. Posteriormente, para infectar sistémicamente al hospedador, el virus alcanza el tejido vascular para propagarse vía floema, dándose así un movimiento a larga distancia.

En el movimiento célula a célula, el virus inicialmente tiene que ser transportado desde el sitio de replicación hasta los plasmodesmos ubicados en la periferia de la célula. Estos canales intercelulares constituyen el medio de transporte para que dichos patógenos puedan acceder a las células adyacentes. El transporte célula a célula de muchos virus de plantas está mediado por factores específicos codificados por el propio virus que se conocen con el nombre de proteínas de movimiento virales (MP), aunque la mayoría de la maquinaria que interviene en dicho transporte es proporcionada por la célula hospedadora. Para ello, el patógeno debe aprovecharse del sistema de tráfico intracelular del hospedador, interviniendo así en dicho proceso elementos del citoesqueleto como microtúbulos (Gillespie et al., 2002; Kragler et al., 2003) y microfilamentos (Liu et al., 2005). Cabría añadir en este escenario de transporte, a una proteína celular que se acumula en los plasmodesmos, la calreticulina. Una unión funcional entre dicha proteína y MP virales ha sido demostrada para el Tobacco mosaic virus (TMV) (Chen et al., 2005). Además, la fosforilación de MP virales por quinasas del hospedador puede regular el tráfico intercelular del virus (Lee \& Lucas, 2001).

Aparte de la maquinaria del hospedador, otras proteínas virales intervienen en el movimiento célula a célula. En el caso de los potyvirus se sabe que la proteína $\mathrm{Cl}$ forma agregados, conocidos como inclusiones cilíndricas, en el citoplasma de células infectadas. Estas inclusiones, al depositarse en la apertura de los plasmodesmos, sugieren que dicha proteína debe ejercer un papel en el movimiento intercelular. También participa en este proceso la 
proteína de cubierta viral $(\mathrm{CP})$, desempeñando la función de aumentar el límite del tamaño de exclusión de los plasmodesmos (Rojas et al., 1997). Por tanto, aunque los potyvirus no codifican MP propiamente dichas, se han asignado funciones de movimiento a varias proteínas codificadas por su genoma.

Se ha postulado una relación entre la acumulación vírica y el movimiento célula a célula del virus, ya que los factores de la traducción eucarióticos elF4E y elF(iso)4E, los cuales se requieren para la acumulación de potyvirus (Duprat et al., 2002; Lellis et al., 2002; Ruffel et al., 2002; Nicaise et al., 2003), también participan en el movimiento intercelular (Gao et al., 2004), mostrándose una propagación limitada del virus cuando la actividad de dichos factores está alterada. Este ejemplo nos indicaría que algunas proteínas del hospedador podrían funcionar en varias etapas del proceso de infección del virus.

El estudio del movimiento a larga distancia no está tan avanzado como el movimiento intercelular debido a la complejidad de las diferentes estructuras celulares implicadas y las conexiones entre ellas. En este movimiento intervienen varias proteínas codificadas por los potyvirus; así, se ha demostrado que tanto la HC-Pro (Kasschau et al., 1997) como la CP (Dolja et al., 1994, Dolja et al., 1995) y la VPg (Rajamäki \& Valkonen, 1999) son esenciales para que el virus lleve a cabo una infección sistémica. Además se cree que en esta etapa del ciclo viral también intervienen factores del hospedador. Un ejemplo de ello son los genes RTM1 (restricted IEV movement 1), RTM2 (restricted IEV movement 2) y RTM3 (restricted IEV movement 3 ) los cuales son requeridos para la restricción del movimiento a larga distancia del TEV en el ecotipo Col-0 de Arabidopsis thaliana (Mahajan et al., 1998; Whitham et al., 1999; Chisholm et al., 2001).

\section{2- Estrategias descritas para generar resistencia a virus}

Existen básicamente dos aproximaciones para desarrollar resistencia a virus basada en ingeniería genética dependiendo de la procedencia de los genes usados. La aproximación empleada con mayor éxito se basa en el concepto de resistencia derivada del patógeno (PDR), que consiste en introducir en la planta genes virales que participen en el ciclo vital del propio virus. Menos conocida es la resistencia no derivada del patógeno, la cual se basa en la utilización, para obtener así plantas transgénicas resistentes a virus, de genes de resistencia del hospedador y otros genes responsables de procesos adaptativos del mismo que responden al ataque patogénico.

\section{Resistencia derivada del patógeno}

Los virus tienen que replicar y encapsidar su genoma, así como propagarse desde el sitio inicial de la infección a través del hospedador hacia sitios distales. En estos procesos participan genes específicos que están codificados por el propio genoma viral y que son 
excelentes candidatos para desarrollar resistencia del hospedador basada en PDR. En muchos cultivos se han desarrollado plantas transgénicas resistentes a virus mediante la introducción en la planta de genes virales que codifican la proteína de cubierta viral (CP), replicasas virales o proteínas de movimiento. El uso de ARNs satélites y genomas defectuosos interferentes también ha estado presente entre las aproximaciones derivadas del patógeno.

La resistencia generada mediante la expresión de la proteína de cubierta fue inicialmente demostrada en tabaco (Abel et al, 1986), donde plantas transgénicas que expresaban el gen que codifica la CP del TMV presentaban un retraso en la aparición de síntomas y un título reducido del virus al comparar con las plantas silvestres. Esta resistencia fue también efectiva frente a otros tobamovirus cuya CP estaba estrechamente relacionada con la del TMV, pero no frente a aquellos virus que filogenéticamente se encontraban alejados del TMV. Aunque se conocen pocos aspectos sobre las bases moleculares que subyacen a este tipo de resistencia, no hay duda de la gran efectividad de la misma. Importantes cultivos se han beneficiado de esta aproximación mediada por la proteína de cubierta de varios virus; entre otros muchos casos cabe mencionar la resistencia generada en tomate al ToMV y al Cucumber mosaic virus (CMV), y la resistencia al Potato virus $X(\mathrm{PVX})$, Potato virus $Y(\mathrm{PVY})$ y al Potato leaf roll virus (PLRV) en cultivos de patata.

La resistencia mediada por replicasas frente a un virus en plantas transgénicas se ha demostrado también en tabaco frente al TMV (Golemboski et al, 1990), desarrollándose resistencias similares frente a otros virus como el Pea early browning virus (PEBV) (MacFarlane \& Davies, 1992), PVY (Audy et al, 1994) y CMV (Hellwald \& Palukaitis, 1995). Las construcciones basadas en genes que codifican replicasas utilizadas para generar resistencia incluyen genes completos, mutados o truncados. El hecho de utilizar construcciones génicas de genes mutados o truncados para generar resistencia demostró que muchas respuestas de resistencia no requieren la síntesis de proteínas virales funcionales sino que deben operar a nivel de ARN, probablemente a través de un silenciamiento génico post-transcripcional. La resistencia mediada por replicasas produce inmunidad pero se limita a un espectro de cepas menor que la resistencia mediada por la proteína de cubierta, la cual confiere resistencia de amplio espectro pero menos completa. (Dasgupta et al., 2003)

Las proteínas de movimiento (MP) son esenciales para el movimiento intercelular de los virus de plantas, ya que modificando la función de apertura de los plasmodesmos permiten que las partículas víricas puedan desplazarse a las células adyacentes. Mediante la producción de MP modificada se obtuvo resistencia frente a TMV en plantas de tabaco. En este caso, parecía darse una competencia entre la MP silvestre codificada por el virus y la afuncional por los sitios de unión de los plasmodesmos (Lapidot et al, 1993). 
Los ADNs defectuosos interferentes son componentes genómicos truncados que interfieren en la replicación del genoma y que han sido detectados en tejidos infectados. La introducción de estas especies de ADN en la planta ha retrasado la aparición de síntomas, con la consecuente recuperación e incremento de la resistencia frente a inoculaciones repetidas (Kunik et al, 1994). Un ejemplo de ello es la resistencia obtenida frente al African cassava mosaic virus (ACMV) en N. benthamiana (Frischmuth \& Stanley, 1993).

\section{Resistencia no derivada del patógeno}

\section{Silenciamiento génico post-transcripcional}

En cuanto a la resistencia no derivada del patógeno, cabe destacar como mecanismo fundamental de defensa antiviral en plantas el silenciamiento génico post-transcripcional (PTGS), también conocido como silenciamiento de ARN. Es un proceso de control de la expresión génica a nivel post-transcripcional que conduce a la supresión de elementos genéticos foráneos como virus y transposones a través de un mecanismo específico de degradación de ARN (Baulcombe, 2004 y 2005). Este mecanismo es el responsable de la habilidad inherente que poseen muchas plantas para degradar ácidos nucleicos de manera específica, regulando así la expresión génica. En este mecanismo, el ARN de doble cadena producido durante la infección viral es degradado a una molécula de 21-25 nucleótidos conocida como ARN pequeño interferente (ARNsi) gracias a la endonucleasa DICER. Este ARNsi, junto a un conjunto de factores tales como polimerasas de ARN dependientes de ARN (RdRp), helicasas de ARN, factores de elongación de la traducción, etc, actúa como ARN guía, teóricamente para degradar moléculas de ARN que tengan homología con la molécula de ARN de doble cadena inicial (Hammond et al., 2001). Este proceso de degradación se inicia en una célula portadora del ARN de doble cadena, y gracias a la expansión de los ARNsi célula a célula y a su propagación a través del floema, el silenciamiento génico se desencadena por todo el organismo de manera sistémica. Este proceso se ha desarrollado como un mecanismo de defensa de la planta frente a virus no sólo de ARN (Smyth, 1999), sino también de ADN (Kjemtrup et al., 1998).

Las plantas tienen varios homólogos de la endonucleasa DICER, conocidas como proteínas tipo DICER (Dicer-like o DCL). En A. thaliana los mutantes dc/1 (dicer-like 1), dcl2 y dc/3 presentan la misma acumulación de ARNsi viral bajo la infección con el TuMV y CMV que las plantas silvestres (Xie et al, 2004). Sin embargo en plantas dcl2 la acumulación viral de ARNsi bajo la infección del TCV se muestra con un cierto retraso, mostrando así un aumento de susceptibilidad. Estudios más recientes (Deleris et al., 2006) avalan la implicación de DCL2 en la defensa antiviral mediada por pequeños ARNs, si bien otorgan a DCL4 un papel primario en dicha respuesta. 
Las polimerasas de ARN dependientes de ARN (RdRp) del hospedador son componentes de la vía del silenciamiento de ARN y parecen tener un papel en las respuestas antivirales. Se ha descrito que la versión mutada de la RdRp de $A$. thaliana RDR6 conduce a una hipersusceptibilidad al CMV y es requerida para el silenciamiento de transgenes (Dalmay et al., 2000; Mourrain et al., 2000). Plantas de tabaco transgénicas que no expresan RdRp1 son más susceptibles al TMV que las plantas silvestres; además, cepas que usualmente no se propagan en tabaco, en estas líneas son capaces de hacerlo tanto a nivel local como a nivel sistémico (Xie et al., 2004).

El hecho de que muchos virus hayan desarrollado mecanismos para suprimir la actividad PTGS del hospedador respalda al silenciamiento de ARN como mecanismo de defensa antiviral. Los virus han sido capaces de codificar supresores de este mecanismo de defensa antiviral innato, inhibiendo diferentes pasos en la vía del silenciamiento para así potenciar la replicación vírica. Uno de los supresores del silenciamiento más conocido es la proteína HC-Pro (helper component-protease) (Anandalakshmi et al. 1998; Brigneti et al. 1998; Kasschau \& Carrington, 1998). Esta proteína, codificada por los potyvirus, ha sido una de las más estudiadas y su función supresora del silenciamiento podría explicar la sinergia que existe en muchas infecciones entre los potyvirus y otros virus. La presencia de un miembro de la familia Potyviridae, permite que virus que normalmente son incapaces de replicarse y propagarse en una planta, puedan provocar una infección sistémica. Asimismo, mutaciones en HC-Pro que eliminan su función supresora causan una pérdida de la habilidad para replicarse y extenderse sistémicamente por parte del virus (Kasschau \& Carrington, 2001).

En los organismos vegetales se conocen al menos tres vías para el silenciamiento de ARN: el silenciamiento citoplasmático por ARNsi, el silenciamiento de ARNm endógenos por microARN (ARNmi) y el silenciamiento asociado a la metilación de ADN y supresión de la transcripción (Baulcombe, 2004). A día de hoy el silenciamiento citoplasmático por ARNsi ha sido el más utilizado en ingeniería genética para conferir resistencia a los virus de plantas, si bien en este caso debería considerarse como un mecanismo de resistencia derivada del patógeno. Entre los requerimientos que presentan las tecnologías basadas en el silenciamiento de ARN cabe destacar una alta especificidad de secuencia para la degradación del ARN (Ritzenthaler, 2005) y un tamaño adecuado del transgén necesario para desencadenar un silenciamiento eficiente. Pero la mayor limitación técnica para estas aproximaciones radica en la dificultad para transformar muchas especies de plantas cultivables.

\section{Genes de resistencia}

Dentro de la resistencia no derivada del patógeno, en otros casos se ha recurrido a la expresión de genes de resistencia de la planta o genes $R$. Estos genes son los responsables del reconocimiento del invasor mediante la interacción directa o indirecta del producto de su 
expresión con factores de avirulencia (Avr) del patógeno. Dicho reconocimiento desencadena un programa de muerte celular en el sitio de infección o reacción hipersensible que bloquea la dispersión del patógeno y conduce a la activación de la respuesta defensiva.

La mayoría de los genes de resistencia a virus pertenecen a la superfamilia de genes $R$ con estructura NBS/LRR, en la que pequeñas variaciones en el dominio LRR permiten variar la especificidad al patógeno (Ellis et al., 2000; Warren et al., 1998). Dentro del grupo de los genes $R$ con estructura NBS/LRR podemos diferenciar varios tipos dependiendo de la naturaleza del dominio N-terminal, así pues pueden presentar un dominio CC (coiled-coil) (CC-NB-LRR), un dominio de cremallera de leucina (LZ-NB-LRR) o un dominio TIR con homología a los dominios de señalización intracelular de los receptores de interleucina de mamíferos y del Toll de Drosophila (TIR-NB-LRR).

Se han identificado genes de resistencia a determinados virus en diferentes especies vegetales, tal como el gen $N$ de tabaco (Nicotiana tabacum), el cual confiere resistencia frente al TMV, siendo un modelo clásico en el estudio de las interacciones planta-virus (Whitham et al., 1994 y 1996; Dineshkumar et al., 1995). El gen $N$ fue descrito en $N$. glutinosa y posteriormente, utilizando técnicas de mejora genética convencional, fue transferido a $N$. tabacum, otorgando resistencia al género Tobamovirus en cultivares comerciales de tabaco. El producto de dicho gen presenta un domino de señalización TIR y un dominio de unión LRR, siendo capaz de reconocer la replicasa del TMV como factor de avirulencia. Este gen es suficiente para la producción de una respuesta hipersensible típica manteniendo dicha efectividad en un sistema heterólogo diferente como tomate (Whitham et al., 1996), donde plantas transgénicas que expresan dicho gen son capaces de desarrollar resistencia frente a este virus. Este fue el primer uso que se hizo de un gen $R$ para proporcionar protección transgénica frente a virus en una planta cultivable.

Otros genes son capaces de desencadenar resistencia por un mecanismo diferente; este es el caso del gen RTM1 de Arabidopsis thaliana. Este gen es capaz de generar una resistencia frente al TEV, independiente de HR y de la activación de la resistencia sistémica adquirida, afectando a su movimiento a larga distancia (Chisholm et al., 2000; Whitham et al., 2000).

En Arabidopsis, el ecotipo C24 resiste a la cepa Y del CMV (CMV-Y) debido a la

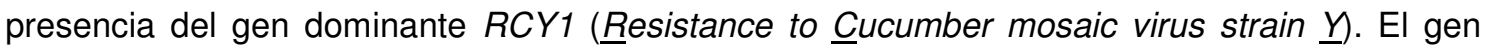
$R C Y 1$ se encuentra en el cromosoma $\mathrm{V}$ de Arabidopsis, donde se localizan otros genes de resistencia como RAC3, RPS4, HRT y TTR1, representando una proteína con estructura CCNB-LRR. La obtención de virus quiméricos entre CMV-Y y la cepa virulenta CMV-B2, permitió identificar a la CP como el factor de avirulencia de CMV-Y (Takahashi et al., 2001). En la 
respuesta de resistencia mediada por $R C Y 1$ intervienen el ácido salicílico y etileno (Takahashi et al., 2004).

Se han identificado otros genes antivirales pero no se ha descrito un uso de los mismos para generar resistencia frente a virus en cultivos de plantas. Cabe destacar entre otros, los genes Sw-5 (Brommonschenkel \& Tanksley, 1997) y Tsw (Jahn et al, 2000) de tomate y pimiento respectivamente, frente al Tomato spotted wilt virus (TSWV), el gen Ry (Mestre et al, 2000) de Solanum stoloniferum frente al PVY, el gen Va de N. tabacum cultivar Burley (Nicolas et al, 1997) frente al Tobacco vein mottling virus (TVMV), el gen TuRB01 de Brassica napus frente TuMV (Jenner et al, 2000), etc...

También se han identificado genes con similitud estructural en especies de interés agronómico denominados análogos a genes de resistencia (RGA) (Shen et al., 1998; Deng et al., 2000; Di Gaspero \& Cipriani, 2002; Baldi et al., 2004; Dondini et al., 2004; Soriano et al., 2005).

Existen evidencias de que puede haber una cierta conexión entre las vías de defensa antivirales del silenciamiento de ARN y la mediada por los genes $R$. Se han descrito proteínas que pueden funcionar como supresores del silenciamiento y como determinantes Avr en defensa mediada por genes $R$; un ejemplo de ello es el caso de la proteína de cubierta del TCV (Qu et al, 2003). Es posible que en el cruce de ambas vías esté presente el SA; una evidencia que apoya este hecho es la inducción de la RdRp RDR1 en respuesta al tratamiento por SA y a la infección vírica (Xie et al, 2001; Yang et al, 2004; Yu et al, 2003). Además existen evidencias de que el SA podría aumentar la defensa antiviral mediada por silenciamiento de ARN, ya que la restricción del movimiento sistémico del PPV en Nicotiana tabacum puede ser aliviada por la expresión del enzima salicilato hidroxilasa (NahG) (Alamillo et al, 2006). Esto conduciría a la existencia de un posible solapamiento entre la resistencia mediada por genes $R$ y el silenciamiento de ARN. Así, el entendimiento de cómo ambas vías interseccionan y cómo una puede influir sobre la otra sería muy útil para una mayor comprensión de los mecanismos de defensa a la enfermedad en plantas.

A pesar de los avances obtenidos en este campo, dado que los genes de resistencia normalmente reconocen específicamente determinadas estirpes del patógeno, su aplicabilidad general es muy limitada. Los virus de plantas tienen la capacidad de mutar y evolucionar rápidamente debido a la existencia de una gran variación genética desencadenada por recombinaciones y a la adquisición de genomas adicionales. Estas características les otorgan la capacidad de modificar los genes Avr y evadir eventualmente las barreras defensivas de las plantas hospedadoras. Por tanto, esta rápida evolución de cepas virales capaces de eludir los mecanismos de resistencia de la planta demanda nuevos conceptos en el desarrollo de variedades vegetales resistentes a patógenos. 


\section{$\underline{\text { Resistencia recesiva }}$}

En contraste con la resistencia de carácter dominante mediada por genes $R$ y el silenciamiento de ARN, existen mecanismos alternativos de resistencia recesivos. En el caso de los virus, a diferencia de los patógenos fúngicos o bacterianos, la resistencia de la planta se basa en gran parte en rasgos de genética recesiva. Esta resistencia se podría definir como el resultado de un mecanismo pasivo que hace a una planta resistente debido a la ausencia de un factor específico del hospedador requerido por el virus para completar su ciclo, o debido a la presencia de una versión mutada de este factor (Fraser, 1990 y 1999). La información disponible sobre interacciones incompatibles entre virus y plantas controlada en el hospedador por genes de resistencia recesivos es menor y más dispersa (Díaz-Pendón et al., 2004). Los virus dependen de la maquinaria bioquímica del hospedador para completar su ciclo biológico. Así, la infección con éxito de una planta requiere una serie de interacciones entre factores del hospedador y factores virales a lo largo de un proceso complejo que incluye la expresión y replicación del genoma viral, el movimiento célula a célula y la translocación a larga distancia a través del sistema vascular de la planta (Carrington et al., 1996; Maule et al., 2002). Algunos de estos factores del hospedador requeridos para la expresión génica del virus o su replicación, se han identificado mediante el análisis de poblaciones mutagenizadas. Así, en $A$. thaliana se ha demostrado que TOM1 (tobamovirus multiplication 1) y TOM2A son necesarios para una eficiente multiplicación de TMV en protoplastos de Arabidopsis, ya que los mutantes tom1 y tom2A muestran deficiencia en la multiplicación del ARN de los tobamovirus. Se trata de proteínas transmembrana del hospedador que interaccionan entre ellas y con proteínas de la replicación viral codificadas por el virus, siendo esenciales para formar el complejo de replicación tobamoviral (Hagiwara et al., 2003; Ishikawa et al., 1991 y 1993; Ohshima et al., 1998; Tsujimoto et al., 2003; Yamanaka et al., 2000 y 2002). Con una aproximación similar, también se demostró que la isoforma del factor de inicio de la traducción eucariótico elF(iso)4E era necesaria para la multiplicación del potyvirus TuMV y del TEV (Duprat et al., 2002; Lellis et al., 2002; Whitham et al., 1999). Además, se han identificado varios mutantes de Arabidopsis en los cuales está restringido el movimiento viral, tales como cum1-1 (cucumovirus multiplication 1) y cum2-1, donde está afectada la propagación del virus CMV (Yoshii et al., 1998a) y la del CMV y TCV (Yoshii et al., 1998b), respectivamente; y vsm1 (irus systemic movement 1 ), en el cual el movimiento sistémico de un tobamovirus está específicamente afectado (Lartey et al., 1998). Los mutantes cum1-1 y cum2-1 tienen alterados los genes elF4E y elF4G, respectivamente (Yoshii et al., 2004). La mayoría de los casos de resistencia recesiva se han descrito en especies cultivadas, pero sólo se han identificado genes implicados en pimiento y lechuga, tratándose en ambos casos del factor de inicio de la traducción elF4E, y frente a potyvirus (Nicaise et al., 2003; Ruffel et al., 2002). Por tanto, aunque la información disponible sobre los mecanismos responsables es muy escasa, parece existir un estrecho vínculo entre factores de inicio de la traducción y la resistencia a virus (Robaglia \& Caranta, 2006). 
Aún se desconoce la identidad de todos los factores, inherentes al hospedador, involucrados en el ciclo viral. Su conocimiento sigue siendo uno de los mayores desafíos de la virología con objeto de generar resistencia a virus en plantas cultivadas. El rastreo de ecotipos de Arabidopsis para evaluar susceptibilidad a virus también ha contribuido a la identificación de varios genes recesivos que afectan a la multiplicación del virus en la planta. La resistencia recesiva parece ser más frecuente para virus que para otros patógenos; y dentro de los virus dicha resistencia esta mayoritariamente dirigida frente al género Potyvirus que frente a virus de otras familias (Díaz- Pendón et al., 2004). 

OBJETIVOS 



\section{OBJETIVOS}

El objetivo fundamental del proyecto en el que se enmarca esta tesis es la caracterización genética, molecular y funcional de una nueva familia de reguladores transcripcionales, conocidos como factores DBP, y determinar en qué procesos biológicos están implicados y cuál es su contribución a la respuesta defensiva de la planta frente a situaciones de estrés, particularmente biótico. El plan de trabajo que nos propusimos desarrollar se basa en completar la caracterización de DBP1 de tabaco y abordar el estudio de factores similares en Arabidopsis thaliana, para ello nuestros objetivos han sido:

1- Caracterización funcional del factor de transcripción de Nicotiana tabacum DBP1. Búsqueda de genes homólogos y análisis de secuencia a fin de establecer relaciones estructura-función para estos factores. Identificación de proteínas que interaccionan con el factor DBP1

2- Análisis funcional del factor regulador AtDBP1 de Arabidopsis thaliana. Identificación de factores proteicos capaces de interaccionar con dicho factor.

3- Búsqueda de los posibles procesos biológicos en los cuales participa AtDBP1 mediante la identificación de genes diana del mismo. 

RESULTADOS Y DISCUSIÓN 

CAPÍTULO 1 



\title{
A Novel DNA-Binding Motif, Hallmark of a New Family of Plant Transcription Factors ${ }^{1,2}$
}

\author{
José L. Carrasco, Gema Ancillo ${ }^{3}$, María José Castelló, and Pablo Vera* \\ Instituto de Biología Molecular y Celular de Plantas, Universidad Politécnica de Valencia, \\ Consejo Superior de Investigaciones Científicas, 46022 Valencia, Spain
}

A novel family of plant-specific transcription factors is described. They are structurally related to DBP1 (for DNA-binding protein phosphatase 1), a new transcription factor recently characterized in tobacco (Nicotiana tabacum), which exhibits both sequencespecific DNA-binding and protein phosphatase activity (Carrasco et al., 2003). The C-terminal part of DBP factors shows high sequence similarity to protein phosphatases of the $2 \mathrm{C}$ class (PP2C; Smith and Walker, 1996), and recombinant tobacco DBP1 is indeed an active protein phosphatase (Carrasco et al., 2003). Within the N-terminal region of these factors, with no significant homology to known protein sequences, we have identified and functionally characterized a novel and highly conserved motif involved in sequence-specific DNA binding. Protein phosphorylation/dephosphorylation enables cells to rapidly and reversibly modulate transcription factor function, and thereby gene expression, in response to signaling stimuli (Whitmarsh and Davis, 2000; Kobor and Greenblatt, 2002). This modulation is accomplished by the coordinated activity of protein kinases and protein phosphatases. Originally considered to act merely by reversing the effects of protein kinases, protein phosphatases are now recognized to fulfill essential regulatory functions in signaling pathways (Luan, 2003). In the last years, biochemical and genetic studies have identified PP2Cs as negative modulators of stressresponsive signaling pathways in animals, yeast, and also in plants (Maeda et al., 1994; Sheen, 1996; Gaits et al., 1997; Meskiene et al., 1998; Takekawa et al., 1998; Gosti et al., 1999; Meskiene et al., 2003). The identified

\footnotetext{
${ }^{1}$ This work was supported by the Spanish Ministry of Science and Technology (grant to P.V.).

${ }^{2}$ We wish to dedicate this article to the loved and esteemed memory of Prof. Dr. Julio López-Gorgé, Department of Plant Biochemistry, Cell and Molecular Biology, Estación Experimental del Zaidín, Consejo Superior de Investigaciones Científicas, Granada, Spain, who died June 7, 2004, at the age of 69.

${ }^{3}$ Present address: Instituto Valenciano de Investigaciones Agrarias, Carretera Moncada-Náquera, km. 4.5, 46113 Moncada (Valencia), Spain.

* Corresponding author; e-mail vera@ibmcp.upv.es; fax 34963877859.

www.plantphysiol.org/cgi/doi/10.1104/pp.104.056002.
}

DBP1 protein from tobacco plants was found to participate in the transcriptional regulation of the expression of the CEVI1 gene (Carrasco et al., 2003), a defenserelated gene that is induced in susceptible plants as a consequence of viral infection (Mayda et al., 2000). Plant PP2Cs are characterized by the presence of specific, sequence-unrelated N-terminal extensions of undefined function (Rodríguez, 1998). Thus, specific functional features of DBP1, like its DNA-binding capacity, likely rest on this region, although sequence analysis did not result in the identification of any obvious, previously characterized DNA-binding motif. Because of the unique combination of protein phosphatase activity and sequence-specific DNA binding within the same protein molecule, the identification of tobacco DBP1 unveiled a new mechanism of transcriptional control remaining to be fully elucidated.

With the aim of further characterizing this novel class of transcriptional regulators, we have investigated the function of the distinctive N-terminal region of DBP1 on the hypothesis that it would likely be involved in DNA-protein interactions. By using TBLASTN (Altschul and Gish, 1996), with the BLOSUM62 matrix and a reference E-value of 0.01, we compared the $\mathrm{N}$-terminal region of DBP1 with sequences in the National Center for Biotechnology Information, The Arabidopsis Information Resource, and The Institute for Genomic Research databases. Significant hits were found only in plants and corresponded to proteins also bearing downstream PP2C domains. Sequence alignment of the $\mathrm{N}$-terminal region of the identified DBP-like factors (Fig. 1A) denotes the existence of a conserved domain, comprising a motif almost invariant in all the aligned sequences from both monocot and dicot plant species. This highly conserved motif, $\mathrm{F}(\mathrm{L}, \mathrm{V}) \mathrm{PX}(\mathrm{L}, \mathrm{V}, \mathrm{I}) \mathrm{RSG}$ XWSDIG, which we refer to as DNC motif (for DBP N-terminal core), might represent a structural element critical for DBP function. By contrast, sequences within the very $\mathrm{N}$ terminus are more divergent, although keep significant similarity within taxa, and could confer functional specificity. Full-length deduced amino acid sequences could be retrieved from only some of the identified CDNAs, the rest corresponding to expressed sequence tags. With the full-length sequences, we generated phylogenetic trees using Phylip programs based on the Neighbor-Joining method, and the FitchMargoliash and least-squares methods (Fig. 1B). 
A

\begin{tabular}{|c|c|}
\hline iv1 & BE258447 \\
\hline Hv2 & CA019985 \\
\hline & AL822602 \\
\hline a2 1 & $B Q 608630$ \\
\hline & BE 400700 \\
\hline & BE493868 \\
\hline $2 \mathrm{~m} \mathrm{~T}$ & TC263473 \\
\hline os 1 & AP003019 \\
\hline Os2 & CB 654058 \\
\hline Sp B & BG560423 \\
\hline $\mathrm{Sb} \mathrm{C}$ & CF071658 \\
\hline Mc1 & CA838286 \\
\hline $\mathrm{Mc2}$ & AB083481 \\
\hline At A & AF 326901 \\
\hline Mt $\mathrm{B}$ & BG452220 \\
\hline $\mathrm{Gm}$ B & BE807797 \\
\hline Ls $B$ & BU003887 \\
\hline In $B$ & BJ554393 \\
\hline $\mathrm{Vv} \mathrm{C}$ & CF211377 \\
\hline $\mathrm{Ca} \mathrm{Bt}$ & BM064889 \\
\hline Le $B C$ & BG133234 \\
\hline St $\mathrm{BC}$ & BG351439 \\
\hline & \\
\hline
\end{tabular}

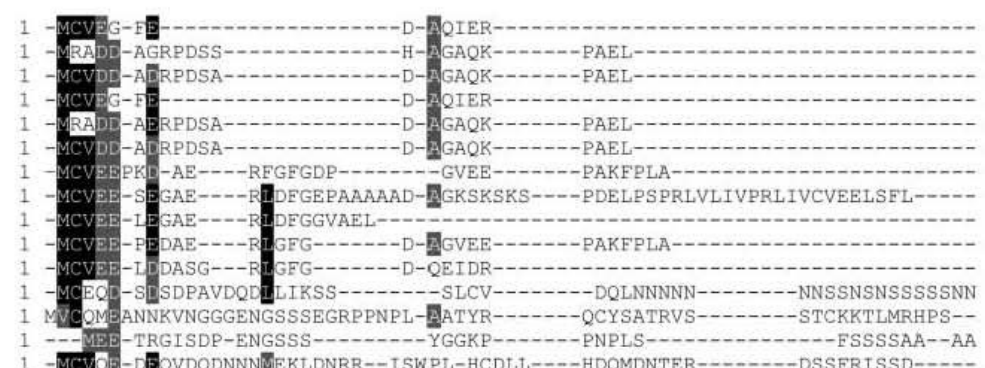

E-TRGISDP-ENGSSS-
DEOVDQDNNN

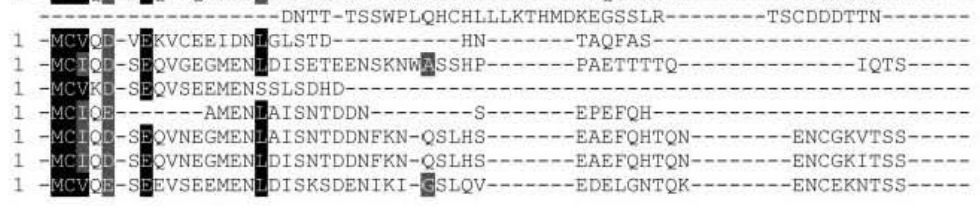

Hv1 BE258447 $\begin{array}{ll}\text { Hv1 } & \text { BF258447 } \\ \text { Hv2 } & \text { CA019985 }\end{array}$ Hv2 CA019985 Ta2 AL822602 Ta2 $\mathrm{BQ} 608630$ Ta3
SC $B E 4900700$
BE 4968 $\mathrm{Zm} \mathrm{TC2} 63473$ OS1 AP003019 Os2 CB654058 Sp BG560423 Sb CF071658 MC1 CA838286 Mc2 AB083481 At AF 326901 Mt BG452220 Gm BE807797 Is BU003887 In BJ554393 VV CF211377 Ca BM064889 Le BG133234 St BG351439 Nt1 AF520810 NtDNCmut 1 NtDNCmut2
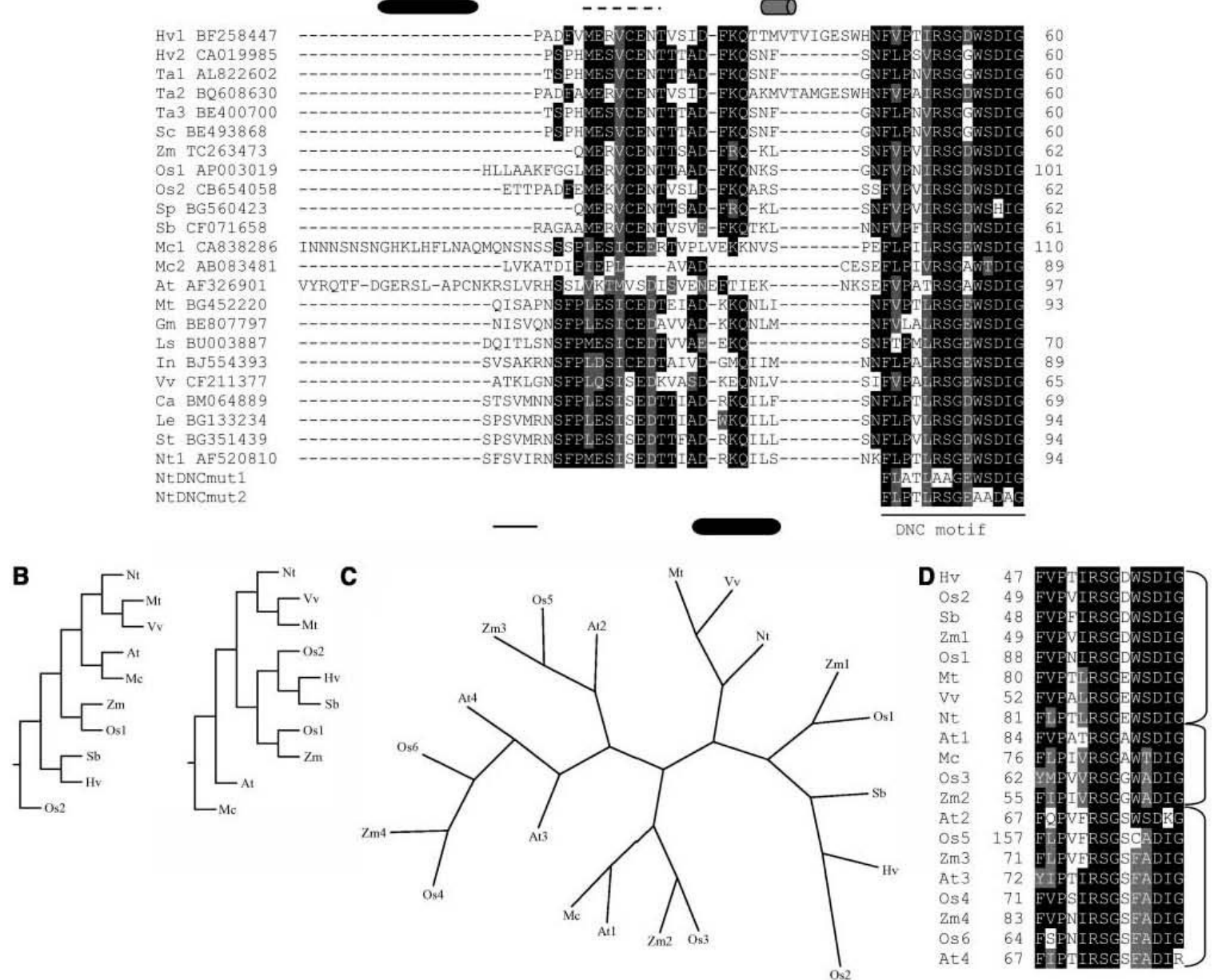

Figure 1. A, Multiple sequence alignment of the $\mathrm{N}$-terminal regions of the identified DBP-like factors. The alignment was generated with T-coffee (http://igs-server.cnrs-mrs.fr/Tcoffee/; Notredame et al., 2000) and viewed with Boxshade (http:// www.ch.embnet.org/software/BOX_form. html). Black boxes denote sequence identity, whereas gray boxes refer to conservative changes. Dashes indicate gaps included for a better alignment. Species abbreviations: Hv, Hordeum vuigare; Ta, Triticum aestivum; Sc, Secale cereale, Zm, maize; Os, rice; Sp, Sorghum propinquum; Sb, Sorghum bicolor, Mc, Mesembryanthemum crystallinum; At, Arabidopsis; Mt, Medicago truncatula; Gm, Glycine max; Ls, Lactuca sativa; In, Jpomoea nil; VV, Vitis vinifera; 
Common to the generated trees, the two full-length DBP sequences available for rice (Oryza sativa) are placed in separate branches and closer to sequences from other monocot species. This result could be indicative of the existence of different classes of DBP factors and supportive of a functional diversification of this novel family of plant transcriptional regulators. In this respect, reducing the stringency of the homology search revealed the existence of additional full-length sequences encoding DBP1-related PP2Cs in Arabidopsis (Arabidopsis thaliana), maize (Zea mays), and rice, all endowed with a less conserved DNC motif. As shown in Figure $1 \mathrm{C}$, with the exception of $\mathrm{Zm} 2$ and Os3, which cluster close to $\mathrm{Mc}$ and At1, the rest of the newly identified sequences are grouped into a separate branch in a phylogenetic tree generated with Quicktree (Howe et al., 2002) and may represent a different subclass of DBP-related proteins. Remarkably, these phylogenetic relationships, which were defined on the basis of the full-length deduced amino acid sequences, also reflect sequence conservation within the DNC motif (Fig. 1D). According to this criterion, the new DBP-like sequences also fall in a different group, with $\mathrm{Zm} 2$ and $\mathrm{Os} 3$ showing, along with $\mathrm{Mc}$ and $\mathrm{At1}$, an intermediate degree of conservation when compared to the originally identified sequences (Fig. 1D). Some of the amino acid residues exchanged in the new sequences were strictly conserved in the first group of DBP-related factors and shown to be involved in DNA binding to the $3 \mathrm{a} 4$ probe by both tobacco and Arabidopsis DBP1. Whether these additional DBP variants show the same sequence specificity or even retain the capacity of binding DNA remain to be elucidated.

Sequence homology in the N-terminal region among the identified DBP factors suggests functional conservation of the DNA-binding activity inherent to tobacco DBP1. To validate this hypothesis, the Arabidopsis DBP1 homolog was expressed in Escherichia coli fused to a C-terminal hexa-His tag (AtDBP1-his ${ }_{6}$ ). The Arabidopsis protein is distantly related to tobacco DBP1, with sequence similarity in the N-terminal region almost restricted to the DNC motif (Fig. 1A) and separate clustering in phylogenetic trees (Fig. 1B). As shown in Figure 2, the purified AtDBP1-his ${ }_{6}$ recombinant protein was able to bind to the $3 \mathrm{a} 4$ probe in electrophoretic mobility shift assays (EMSA) with similar affinity as tobacco DBP1, the latter also expressed and purified as a C-terminal fusion to a hexa-His tag (DBP1-his ${ }_{6}$ ). The $3 \mathrm{a} 4$ probe derives from the promoter of the CEVI-1 gene (Mayda et al., 2000) and is specifically recognized in vitro by DBP1 (Carrasco et al., 2003). To analyze the implication of the N-terminal region of tobacco DBP1 in sequence-specific DNA binding, a fusion protein consisting of the maltose-binding protein (MBP) and the $\mathrm{N}$-terminal region of DBP1 (MBP-DBP1Nt) was expressed in $E$. coli. The purified recombinant protein was able to bind to the radiolabeled $3 \mathrm{a} 4$ DNA probe in vitro, whereas MBP alone was not (Fig. 3A, lanes 2 and 3 ). In addition, binding to the $3 \mathrm{a} 4$ probe mediated by the $\mathrm{N}$-terminal region of DBP1 showed the same sequence specificity as the full-length protein; thus, the 3a4mut double-stranded oligonucleotide, which is not recognized by DBP1 (Carrasco et al., 2003), was not bound by MBP-DBP1Nt (Fig. 3A, lane 6). Therefore, sequencespecific DNA binding relies on amino acid residues in the N-terminal region of DBP1. Moreover, the N-terminal region of Arabidopsis AtDBP1 also retained DNA-binding activity when expressed in E. coli as an $\mathrm{MBP}$ fusion protein (MBP-AtDBP1Nt), and showed the same sequence specificity as full-length tobacco DBP1 and DBP1-Nt (Fig. 3A, lanes 4 and 7).

The results described above strongly suggest that the highly conserved DNC motif of DBP factors is involved in DNA binding. If this is true, mutations in conserved positions within the DNC motif should interfere with its ability to interact with DNA. Therefore, two mutated versions of the $\mathrm{N}$-terminal region of tobacco DBP1 were expressed in E. coli and purified as translational fusions to MBP (MBP-DNCmut1 and MBP-DNCmut2). The introduced amino acid changes in each mutated protein are shown in Figure 1A. They were all Ala substitutions affecting highly conserved positions within the DNC motif. Both MBP-DNCmut1 and MBP-DNCmut2 purified recombinant proteins were analyzed in EMSA for their ability to bind to the 3a4 probe. As shown in Figure 3B, mutations introduced in the DNC motif significantly reduce the capacity of the $\mathrm{N}$-terminal region of DBP1 to interact with its target DNA. These results indicate that sequence integrity of the DNC motif is critical for interaction with DNA, and provide conclusive evidence for the direct implication of this motif in DNA binding.

Figure 1. (Continued.)

Ca, Capsicum annuum; Le, Lycopersicon esculentum; St, Solanum tuberosum; and Nt, tobacco. The GenBank accession number of each sequence is given. The consensus secondary structure prediction for the DBP1 N-terminal region provided by the Network Protein Sequence @nalysis server (NPS@; http:/npsa-pbil.ibcp.fr) using default parameters (Combet et al., 2000) is indicated below the amino acid sequence; $\alpha$-helices and $\beta$-strands are shown as cylinders and lines, respectively. Gray cylinder and dashed line denote uncertain prediction. The amino acid sequence of the DNC motif in the mutated DBP1 proteins is included at the bottom of the alignment. B, Phylogenetic trees generated using Phylip programs (http://bioweb.pasteur.fr/seqanal/ phylogeny/phylip-uk.html). Full-length amino acid sequences were aligned using T-coffee (http://igs-server.cnrs-mrs.fr/Tcoffee/; Notredame et al., 2000). Left, Phylogenetic tree provided by Quicktree, a program for the rapid reconstruction of phylogenies by the Neighbor-Joining method (Howe et al., 2002). Right, Phylogenetic tree obtained with Fitch, a program that uses the FitchMargoliash and some related least-squares criteria. C, Unrooted phylogenetic tree generated with Quicktree (Howe et al., 2002), including full-length sequences containing less conserved DNC motifs. D, Multiple sequence alignment of the DNC motifs of the DBP-related sequences used in C. 


\section{DISCUSSION}

In the last few years, direct links between protein phosphorylation and function of DNA-bound transcription regulatory complexes have been reported. Accordingly, ERK5, a mouse mitogen-activated protein kinase, contributes a potent transcription activation domain after recruitment to the promoter of specific target genes by a MEF2 family transcription factor and functions as a coactivator in the transcriptional induction of genes involved in immature $\mathrm{T}$ cell apoptosis (Kasler et al., 2000). Similarly, Hog1, another mitogenactivated protein kinase, has been found to be part of transcription activating complexes and essential for transcriptional induction of some stress-responsive genes in yeast. Hog1 is recruited by the transcription

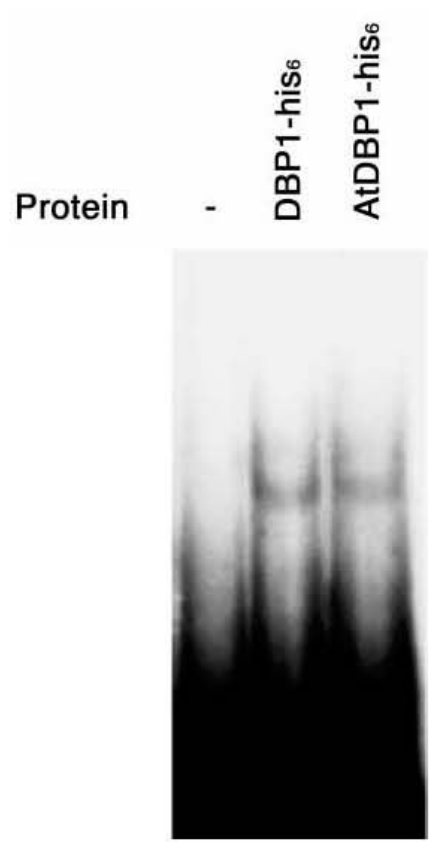

Figure 2. Assay of in vitro DNA binding by full-length DBP1 and AtDBP1. Recombinant full-length DBP proteins were expressed in $E$. coli bearing a C-terminal hexa-His tag, purified by nickel affinity chromatography according to the manufacturer's instructions (Qiagen, Valencia, CA), and assayed for their ability to bind to the doublestranded $3 \mathrm{a} 4$ oligonucleotide probe as described (Carrasco et al., 2003). Briefly, complementary oligonucleotides leaving 5 ' protruding ends were annealed and radioactively labeled using the Klenow fragment of $E$. coli DNA polymerase $\mathrm{l}$. The sequences of the oligonucleotides used to build the double-stranded $3 a 4$ probe are the following, with the nucleotides modified in the mutated 3 a4mut probe shown in bold: 3a4-plus, 5'-TCGACTAGGCGGCTAATATTTGCCTTTGTCTCCCTC-3'; and 3a4-minus, 5'-TCGAGAGGGAGACAAAGGCAAATATTAGCCGCCTAG-3'. Purified proteins (1 $\mu \mathrm{M})$ were incubated for $10 \mathrm{~min}$ at room temperature with the radiolabeled DNA probe $(0.3 \mathrm{nM})$ in binding buffer [20 $\mathrm{mm} \mathrm{HEPES}-\mathrm{KOH}, \mathrm{pH} 7.6,4 \mathrm{~mm} \mathrm{KCl}$, $0.1 \mathrm{~mm}$ EDTA, $1 \mathrm{~mm}$ dithiothreitol, 10\% ( $\mathrm{v} / \mathrm{v}$ ) glycerol], prior to separation on a native $6 \%(w / V)$ polyacrylamide gel in $0.5 \times$ Tris-borate/ EDTA buffer.
A

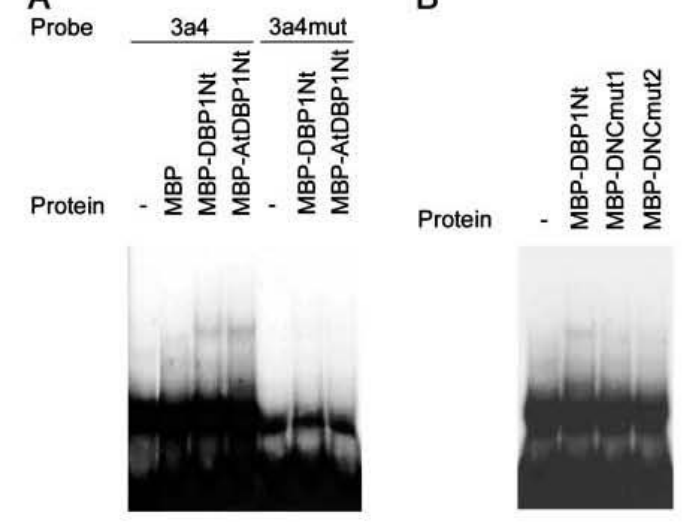

B
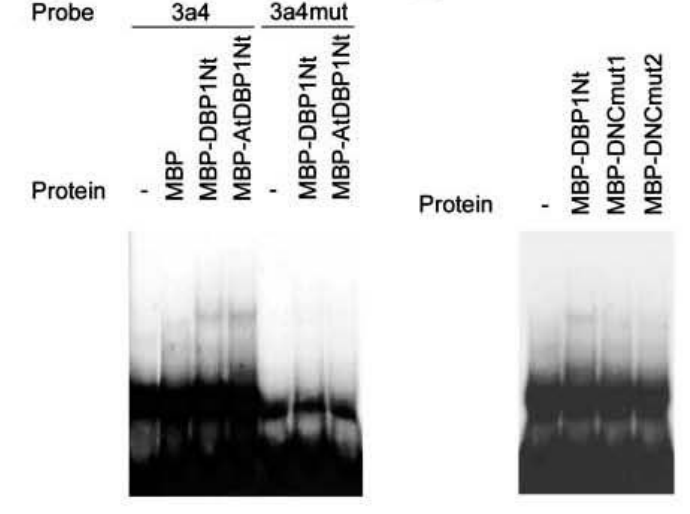

C

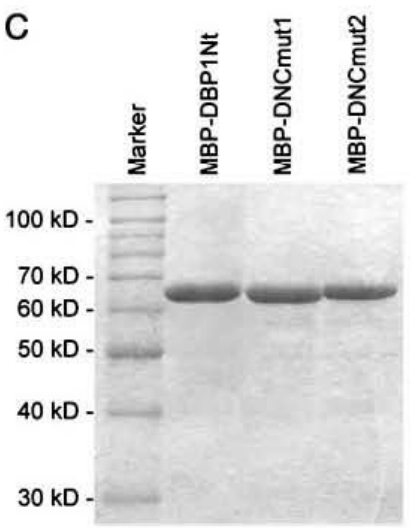

Figure 3. A, DNA binding in vitro by the $\mathrm{N}$-terminal regions of $\mathrm{DBP} 1$ and $A t D B P 1$. Recombinant MBP fusion proteins were expressed in $E$. coli and purified by amylose affinity chromatography, according to the manufacturer's instructions (New England Biolabs, Beverly, MA). Electrophoretic mobility shift assays were performed as described above. The sequences of the oligonucleotides used to generate the double-stranded mutated probe 3 a4mut are the following, with changed nucleotides shown in bold: 3a4mut-plus, 5'-TCGACTAGGCGGCAGGAGTTTGGGAGAGTCTCCCTC-3'; and 3a4mut-minus, 5'-TCGAGAGGGAGACTCTCCCAAACTCCTGCCGCCTAG-3'. Both $3 \mathrm{a} 4$ and $3 \mathrm{a} 4$ mut probes were radioactively labeled as described above. Labeling was quantified by liquid scintillation and found to be almost identical in both cases. The same amount of each labeled probe was used in EMSA. B, Effect of mutations in the DNC motif on DNA binding by the N-terminal region of DBP1. Mutations in MBP-DNCmut1 and MBP-DNCmut2 were introduced using the megaprimer method (Datta, 1995). Mutant proteins were expressed in E. coli and purified as described above. Purified recombinant proteins were incubated at a final concentration of $1 \mu \mathrm{M}$ with a radiolabeled $3 \mathrm{a} 4 \mathrm{DNA}$ probe $(0.3$ $\mathrm{nM})$ for $10 \mathrm{~min}$ at room temperature in binding buffer $[20 \mathrm{mM} H \mathrm{HEPES}$ $\mathrm{KOH}, \mathrm{pH} 7.6,4 \mathrm{~mm} \mathrm{KCl}, 0.1 \mathrm{~mm}$ EDTA, $1 \mathrm{~mm}$ dithiothreitol, $10 \%(\mathrm{v} / \mathrm{v})$ glycerol], prior to electrophores is on a native $6 \%(\mathrm{w} / \mathrm{v})$ polyacrylamide gel in $0.5 \times$ Tris-borate/EDTA buffer. C, SDS-PAGE of purified recombinant proteins used in EMSA. 
factor Hot1 to the promoter of these stress-inducible genes (Alepuz et al., 2001), where, in turn, it mediates recruitment of a histone deacetylase activity and the RNA polymerase II holoenzyme (Alepuz et al., 2003; de Nadal et al., 2004). Another example is eyes absent, a nuclear protein Tyr phosphatase implicated in mammalian organogenesis, which acts as a coactivator through an interaction with homeodomain-containing proteins ( $\mathrm{Li}$ et al., 2003). DBP1 represents one step forward in this direction since it is a protein phosphatase directly targeted to specific gene promoters by an intrinsic sequence-specific DNA-binding activity, without the need for a recruiting protein partner. We have now identified the DNC motif as involved in this specific DNA binding. Furthermore, we have described a large family of putative new transcription factors related to tobacco DBP1. These factors, apparently unique to plants, are all endowed with a PP2C catalytic domain and characterized by an $\mathrm{N}$-terminal region with the herein identified and highly conserved DNC DNAbinding motif, also functional in the distantly related Arabidopsis DBP1 homolog AtDBP1, as the most salient signature of the family. Sequence conservation of this motif throughout the plant kingdom suggests that DBP factors might bind similar sequences, although a contribution to sequence specificity by additional residues cannotbe excluded. The identification of target genes of DBP factors and interacting protein partners is an exciting challenge for the near future, and should help establish the mechanistic basis of the regulatory function of this novel class of transcription factors and the signaling pathways they are involved in.

\section{ACKNOWLEDGMENT}

We thank Dr. Peter Tompa (Institute of Enzymology, Budapest) for his invaluable advice and for critical reading of the manuscript.

Received November 3, 2004; November 26, 2004; December 2, 2004.

\section{LITERATURE CITED}

Alepuz PM, de Nadal E, Zapater M, Ammerer G, Posas F (2003) Osmostress-induced transcription by Hot1 depends on a Hog1-mediated recruitment of the RNA Pol II. EMBO I 22: 2433-2442

Alepuz PM, Jovanovic A, Reiser V, Ammerer G (2001) Stress-induced MAP kinase Hog1 is part of transcription activation complexes. Mol Cell 7: 767-777
Altschul SF, Gish W (1996) Local alignment statistics. Methods Enzymol 266: $460-480$

Carrasco JL, Ancillo G, Mayda E, Vera P (2003) A novel transcription factor involved in plant defense endowed with protein phosphatase activity. EMBO I 22: 3376-3384

Combet C, Blanchet C, Geourjon C, Deléage G (2000) NPS@: Network Protein Sequence Analysis. Trends Biochem Sci 25: 147-150

Datta AK (1995) Efficient amplification using "megaprimer" by asymmetric polymerase chain reaction. Nucleic Acids Res 23: 4530-4531

de Nadal E, Zapater M, Alepuz PM, Sumoy L, Mas G, Posas F (2004) The MAPK Hog1 recruits Rpd3 histone deacetylase to activate osmoresponsive genes. Nature 427: $370-374$

Gaits F, Shiozaki K, Russell P (1997) Protein phosphatase 2C acts independently of stress-activated kinase cascade to regulate the stress response in fission yeast. J Biol Chem 272: 17873-17879

Gosti F, Beaudoin N, Serizet C, Webb AAR, Vartanian N, Giraudat J (1999) ABI1 protein phosphatase $2 \mathrm{C}$ is a negative regulator of abscisic acid signaling. Plant Cell 11: 1897-1909

Howe K, Bateman A, Durbin R (2002) QuickTree: building huge Neighbour-Joining trees of protein sequences. Bioinformatics 18: 1546-1547

Kasler HG, Victoria J, Duramad O, Winoto A (2000) ERK5 is a novel type of mitogen-activated protein kinase containing a transcriptional activation domain. Mol Cell Biol 20: 8382-8389

Kobor MS, Greenblatt J (2002) Regulation of transcription elongation by phosphorylation. Biochim Biophys Acta 1577: 261-275

Li X, Ohgi KA, Zhang I, Krones A, Bush KT, Glass CK, Nigam SK, Aggarwal AK, Maas R, Rose DW, et al (2003) Eya protein phosphatase activity regulates Six1-Dach-Eya transcriptional effects in mammalian organogenesis. Nature 426: 247-254

Luan S (2003) Protein phosphatases in plants. Annu Rev Plant Physiol Plant Mol Biol 54: 63-92

Maeda T, Wurgler-Murphy SM, Saito H (1994) A two-component system that regulates an osmosensing MAP kinase cascade in yeast. Nature 369: $242-245$

Mayda E, Marqués C, Conejero V, Vera P (2000) Expression of a pathogeninduced gene can be mimicked by auxin insensitivity. Mol Plant Microbe Interact 13: 23-31

Meskiene I, Baudouin E, Schweighofer A, Liwosz A, Jonak C, Rodríguez PL, Jelinek H, Hirt H (2003) Stress-induced protein phosphatase $2 \mathrm{C}$ is a negative regulator of a mitogen-activated protein kinase. J Biol Chem 278: 18945-18952

Meskiene I, Bögre L, Glaser W, Balog J, Brandstötter M, Zwerger $K$, Ammerer G, Hirt H (1998) MP2C, a plant protein phosphatase 2C, functions as a negative regulator of mitogen-activated protein kinase pathways in yeast and plants. Proc Natl Acad Sci USA 95: 1938-1943

Notred ame C, Higgins DG, Heringa J (2000) T-Coffee: a novel method for fast and accurate multiple sequence alignment. J Mol Biol 302: 205-217

Rodríguez PL (1998) Protein phosphatase 2C (PP2C) function in higher plants. Plant Mol Biol 38: 919-927

Sheen J (1996) $\mathrm{Ca}^{2+}$-dependent protein kinases and stress signal transduction in plants. Science 274: 1900-1902

Smith RD, Walker JC (1996) Plant protein phosphatases. Annu Rev Plant Physiol Plant Mol Biol 47: 101-125

Takekawa M, Maeda T, Saito H (1998) Protein phosphatase 2Calpha inhibits the human stress-responsive p38 and JNK MAPK pathways. EMBO I 17: $4744-4752$

Whitmarsh AJ, Davis RJ (2000) Regulation of transcription factor function by phosphorylation. Cell Mol Life Sci 57: 1172-1183 

CAPÍTULO 2 

Tobacco DBP1 is the founding member of a novel class of plant transcription factors featuring sequence-specific DNA binding and protein phosphatase activity. To understand the mechanisms underlying the function of this family of transcriptional regulators, we have identified the tobacco 14-3-3 isoform $G$ as the first protein interacting with a DBP factor. 14-3-3 recognition involves the N-terminal region of DBP1, which also supports the DNA binding activity attributed to DBP1. The relevance of this interaction is reinforced by its conservation in Arabidopsis plants, where the closest relative of DBP1 in this species also interacts with a homologous $14-3-3$ protein through its $\mathrm{N}$-terminal region. Furthermore, we show that in planta 14-3-3 $\mathrm{G}$ is directly involved in regulating DBP1 function by promoting nuclear export and subsequent cytoplasmic retention of DBP1 under conditions that in turn alleviate DBP1-mediated repression of target gene expression.

To cope with adverse environmental growth conditions, plants have evolved efficient defense mechanisms that imply changes in the expression of numerous genes that are mostly controlled at the transcriptional level $(1,2)$. Transcription factors are key components of these signaling processes as they are responsible for ultimately executing the transcriptional outputs necessary to mount the pursued adaptation. Upon signal perception, the earliest changes in transcription must be the result of the activity of preexisting transcription factors that are functionally modulated in response to the corresponding signal. Post-translational modifications, particularly protein phosphorylation-dephosphorylation and protein-protein interactions largely account for the regulation of transcription factor function and affect their subcellular localization, stability, DNA binding activity, and/or interactions with additional protein partners.

DBP1 (DNA-binding protein phosphatase 1) was recently identified in tobacco (Nicotiana tabacum) as the first repre-

* This work was supported in part by a grant from the Spanish Ministry of Education and Science (to P.V.). The costs of publication of this article were defrayed in part by the payment of page charges. This article must therefore be hereby marked "advertisement" in accordance with 18 U.S.C. Section 1734 solely to indicate this fact.

Supported by a predoctoral fellowship from the Spanish Ministry of Education and Science.

${ }^{2}$ To whom correspondence should be addressed: Instituto de Biología Molecular y Celular de Plantas, Universidad Politécnica de Valencia-C.S.I.C., Avenida de los Naranjos, s/n, 46022 Valencia, Spain. Tel.: 34-963877884; Fax: 34-963877859; E-mail: vera@ibmcp.upv.es. sentative of a novel class of transcription factors endowed with protein phosphatase activity (3). DBP1 was shown to be involved in the transcriptional modulation of a plant defense gene, the CEVI1 gene, whose transcription is activated in response to detachment (in excised leaf sections) as well as during the course of a compatible plant-virus interaction (4). DBP1-related proteins have been found only in plants, in both monocot and dicot species, and within each species different family members can be identified (5). In all cases, the protein phosphatase $2 \mathrm{C}$ catalytic domain resides in the $\mathrm{C}$-terminal part of the protein, whereas the $\mathrm{N}$-terminal region supports the sequence-specific DNA binding activity of DBP factors (5). Within this latter region a highly conserved $\mathrm{DNC}^{3}$ motif (for DBP $\underline{N}$-terminal Core) was identified. This motif recognizes the previously identified $3 a 4$ cis-acting element present in the promoter region of the CEVI-1 gene and might represent a structural element critical for the function of DBP proteins as transcriptional repressors $(3,5)$. Toward the elucidation of the mechanistic basis underlying the regulatory function of DBP factors we report on the identification of the specific interaction of tobacco DBP1 with 14-3-3 isoform $\mathrm{G}$ and demonstrate that this interaction mediates a nucleocytoplasmic shuttling of DBP1.

\section{EXPERIMENTAL PROCEDURES}

Yeast Two-hybrid Screening-The coding sequence of tobacco DBP1 was cloned into the yeast shuttle vector pAS2-1 (Clontech) in-frame with the GAL4 DNA-binding domain (GAL4BD). The resulting construct was used to transform the yeast strain PJ69-4A (6). A tobacco cDNA library constructed in the vector pAD-GAL4-2.1 (Stratagene) was screened following the polyethylene glycol/LiAc/single-stranded DNA protocoldeveloped by Gietz et al. (7). Positive interacting clones were selected on histidine-lacking medium supplemented with $4 \mathrm{mM}$ 3-amino-triazol (a competitive inhibitor of the HIS3 reporter gene product) and analyzed for activation of the second reporter gene, the $l a c Z$ gene, by $\beta$-galactosidase filter lift assays. Veracity and specificity of the interaction were confirmed by retransformation of the library plasmids into the original bait strain used in the screening and additional control strains. $\beta$-galactosidase activity was then measured by a quantitative liquid culture assay.

${ }^{3}$ The abbreviations used are: DNC, DBP N-terminal core: $M B P$, maltose-bind-
ing protein; GFP, green fluorescent protein; MES, 4-morpholineethanesulfonic acid. 
Tobacco DBP1-interacting Proteins

A

\section{4-3-3 G}

his +

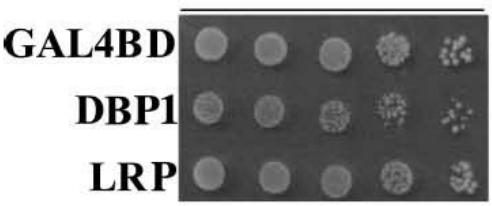

\section{his- 7 mM 3AT}

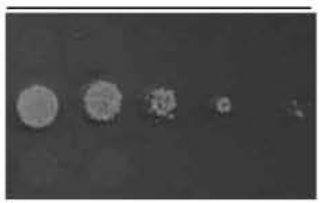

C

$\begin{array}{llllll}1 & 2 & 3 & M & 4 & 5\end{array}$

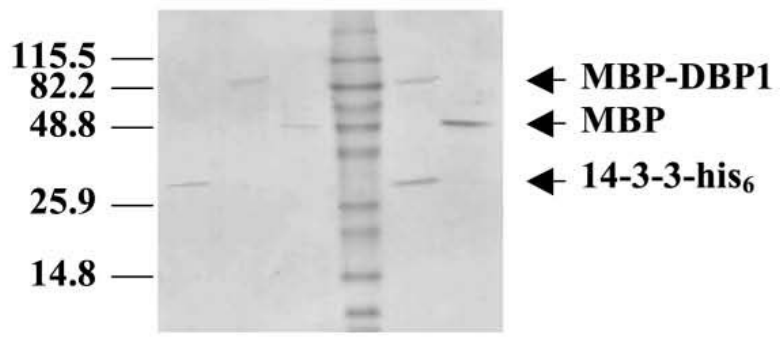

B

\section{Clone 1}

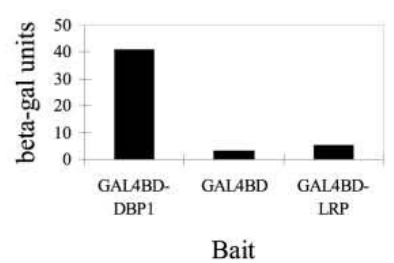

D

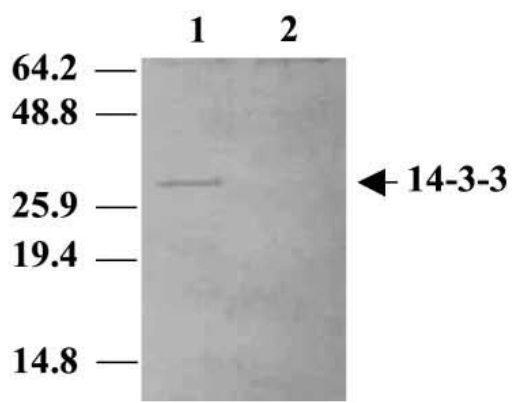

FIGURE 1. 14-3-3 G specifically interacts with to bacco DBP1. A tobacco ( $N$ t tabacum) GAL LAD-CDNA librarywas screened using DBP1 as bait. $A$, yeast growth on medium lacking histidine and supplemented with 3 AT, a competitive inhibitor of the HIS3 gene product, assayed with three different baits, namely GAL4BD-DBP1,GAL4BD, and GAL4BD-LRP. LRP is an unrelated tobacco protein of unknown function. B, $\beta$-galactosidase activitymeasured in extr acts from the GA.4BD-DBPI, GAL4BD, and GAL4BD-LRP. LRP is an unrelated tobacco protein of unknown function. B, $\beta$-galactosidase activitymeasured in extr acts from the
same yeast strains as used in panel A. C, SDS-polyacrylamide gel of eluates obtained after incubating purified MBP-DBP1 (fane 4) and MBP (jane 5) with same yeast strains as used in pane $\mathrm{A}$. C, SDS-polyacrylamide gel of eluates obtained after incubating purified $\mathrm{mBP}$ -

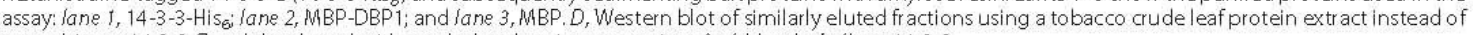
recombinant 14-3-3 $\mathrm{G}$ and developed with a polyclonal antiserum against Arabidopsis thaliana 14-3-3.

An Arabidopsis thaliana two-hybrid cDNA library in the vector PACTI (Clontech) was transformed into PJ69-4 $\alpha$ and screened following the interaction mating protocol developed by Söllick and Uhrig ( 8 ), using as bait the $\mathrm{N}$-terminal region of AtDBP1 expressed in PJ69-4A as a GAL4BD fusion from the pAS2-1 vector. Reporter gene expression was measured and verified as described above.

In Vitro Pulldown Assay-Tobacco DBP1 was expressed in Escherichia coli as a maltose-binding protein (MBP) fusion protein and purified by affinity chromatography on amylose resin (New England Biolabs) according to the manufacturer's instructions. 14-3-3 G was expressed bearing a hexahistidine tag and purified by affinity chromatography on nickelagarose (Qiagen). Purified proteins were combined in $20 \mathrm{~mm}$ Tris-HCl, pH 7.4, $0.15 \mathrm{M} \mathrm{NaCl}, 0.1 \mathrm{~mm}$ EDTA, $0.5 \mathrm{~mm}$ phenylmethylsulfonyl fluoride, $5 \mathrm{~mm} 2$-mercaptoethanol, $0.2 \%$ (v/v) Nonidet P-40, incubated for $1 \mathrm{~h}$ at $4^{\circ} \mathrm{C}$ under gentle shaking, and sedimented with amylose resin. After extensive washing, resin-bound proteins were eluted with loading buffer and analyzed by SDS-polyacrylamide gel electrophoresis. A tobacco crude protein extract was prepared by grinding tobacco leaves under liquid nitrogen, suspending the ground powder in the aforementioned buffer, and removing cell debris by centrifugation. Subsequent incubations were as above. The eluted fraction was subjected to Western blot detection with a polyclonal antiserum raised against Arabidopsis 14-3-3 kindly provided by Robert J. Ferl (University of Florida).

Yeast Nuclear Import Assay-Nuclear targeting was analyzed in vivo using the yeast system developed by Rhee et al. (9). Briefly, the protein of interest is translationally fused to a chimeric transcriptional activator, devoid of any nuclear localization signal and consisting of the DNA-binding domain of the bacterial repressor LexA and the activation domain of the yeast transcriptional activator GAL4. Thus, nuclear import will rely on the presence of a functional nuclear localization signal in the protein under study and will result in the transcriptional activation of the HIS3 and lacZ reporter genes.

Plant Transient Expression Assay by Leaf Infiltration of Agrobacteritm tumefaciens-The cDNA sequences encoding the full-length DBP1 protein and the C-terminal region were cloned in-frame with the smGFP4 coding sequence into the pVR-GFP-Ct Gateway vector. The 14-3-3 isoform G coding sequence was cloned into a binary vector under the control of the CaMV $35 \mathrm{~S}$ promoter. Tobacco plants (Nicotiana benthamiana) were grown in a phytochamber under short day conditions at $23^{\circ} \mathrm{C} / 19^{\circ} \mathrm{C}$. Mid, almost fully expanded leaves were infiltrated with a suspension of $A$. tumefaciens C58 bearing the relevant construct in 10 mM MES, $\mathrm{pH} 5.6,10$ $\mathrm{mM} \mathrm{MgCl}, 150 \mu \mathrm{M}$ acetosyringone at an $A_{600}$ of 0.5 . After 3-4 days, GFP fluorescence was analyzed in infiltrated leaves by confocal microscopy. For co-infiltration, Agrobac- 
terium cultures grown separately and adjusted to an $A_{600}$ of 0.5 were mixed.

\section{RESULTS AND DISCUSSION}

Identification of DBP1-interacting Proteins-To identify proteins involved in the regulatory mechanism mediated by DBP1, we performed a yeast two-hybrid screen of a tobacco GAL4AD-cDNA library using full-length tobacco DBP1 as bait. From $1.5 \times 10^{6}$ transformants analyzed, one clone was identified that activated transcription of the HIS3 and lacZ reporter genes in a DBP1-dependent manner. As shown in Fig. 1, reporter gene activation was assayed in combination with three different baits, the original GAL4BD-DBP1 fusion, the GALABD alone, and a fusion of this domain to an unrelated tobacco protein of unknown function (LRP) (10). The identified cDNA clone supported growth on histidine-lacking medium (Fig. 1A) and deployment of $\beta$-galactosidase activity (Fig. 1B) only in the presence of DBP1. The isolated clone was sequenced and found to encode the 14-3-3 isoform G (GenBank ${ }^{\mathrm{TM}}$ accession number AF299256) (11). 14-3-3's are ubiquitous and conserved eukaryotic proteins encoded by multigene families, and they are recognized as important mediators in the regulation of diverse biological processes, in particular signal transduction and transcription, through direct protein-protein interactions (12-15). Plant 14-3-3 proteins were first identified as components of sequence-specific DNA-protein complexes in Arabidopsis and maize $(16,17)$. More recently they have been found to bind components of the general transcription machinery like TATA-binding protein and TFIIB (18), as well as specific transcription factors and other regulatory proteins with a role in signaling processes related to both developmental and stress response pathways (14).

Interaction of DBP1 with 14-3-3 isoform G was confirmed in vitro in a pulldown assay using purified recombinant proteins. DBP1 was expressed in E. coli as a translational fusion to the maltose-binding protein, and 14-3-3 G was expressed bearing a hexahistidine tag (14-3-3 G-His 6 ). As shown in Fig. 1C, purified MBPDBP1 was able to pull along 14-3-3 G-His ${ }_{6}$ when bound to amylose resin (lane 4), whereas MBP alone was not (lane 5). Furthermore, using a crude protein extract from tobacco leaves, a polyclonal antiserum raised against Arabidopsis 14-3-3 recognized in a Western blot a band of the correct size in the fraction sedimented with amylose resin after incubation with MBP-DBP1 (Fig. 1D, lane 1), but not with MBP alone (lane 2).

Identification of 14-3-3 G-interacting Domains within DBP114-3-3 target recognition largely involves conserved phosphoserine-containing binding sites, and phosphopeptide motifs providing optimal 14-3-3 binding have been identified from peptide libraries (19). Although no sequence motif was found in the DBP1 amino acid sequence conforming to these consensus sites, some 14-3-3-binding proteins interact through phosphorylated motifs that diverge from these consensus sites, and even non-phosphorylated motifs may also provide high affinity binding by $14-3-3$ proteins (13). To locate those regions in DBP1 involved in the interaction with 14-3-3 G, reporter gene activation was assayed in the two-hybrid system using as baits different deletions of DBP1, as depicted in Fig. 2A. When in combination with 14-3-3 G, growth on histidine-lacking medium was
Tobacco DBP1-interacting Proteins

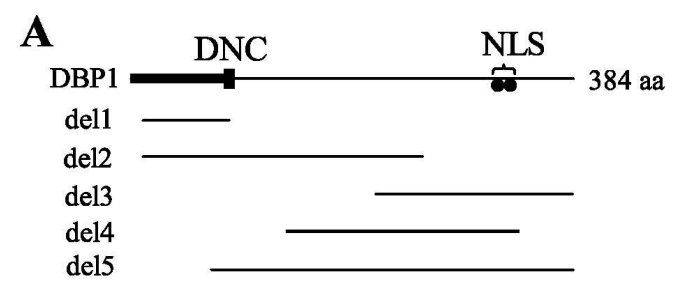

B

14-3-3 G

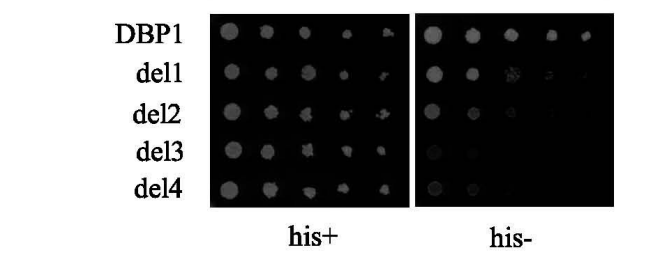

C

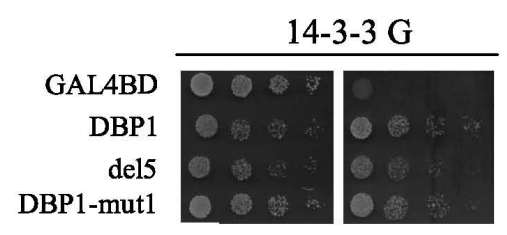

his +

his-

FIGURE 2. Identification of the 14-3-3 G-interacting domain in DBP1. A deletion constructs of DBP1 translationally fused to the GAL4BD coding sequence used as baits in the two-hybrid assay. The thick line in the DBP1 full-length construct refers to the variable $\mathrm{N}$-terminal region shown to be involved in DNA binding. Solid dotsindicate the position of the putative bipartite nuclear localization signal (NLS). $B$ and C, growth on histidine-lacking medium of yeast expressing DBP1 deletion and mutated constructs along with GAL4AD-14-3-3 G. Serial dilutions of a starting culture at an $A_{600}$ of 1 were spotted on medium containing (left) and lacking (right) histidine. In DBP1-mut1, point mutations P83A, R86A, and $587 \mathrm{~A}$ were introduced simultaneously in the full-length DBP1 protein sequence.

observed for full-length DBP1 and the truncated proteins del1 and del 2 (Fig. $2 B$ ). dell comprises the first 87 amino acid residues that roughly encompass the N-terminal region of DBP1 previously shown to directly mediate sequence-specific DNA binding (5). In contrast, del 3 and del4, which both lack this region, failed to sustain the interaction. Therefore, the N-terminal region of DBP1 is necessary and sufficient for recognition of 14-3-3 G. To further delineate the motifs involved in the interaction, one additional deletion construct (del5) was assayed in the two-hybrid system for its capacity to bind 14-3-3 G. As shown in Fig. $2 C$, deletion of the $\mathrm{N}$-terminal region up to position 64 in the context of the full-length DBP1 protein did not prevent 14-3-3 G recognition, narrowing the interaction site to the region encompassing amino acid residues from 64 to 87. We had previously shown that the highly conserved DNC motif at the end of the N-terminal region is engaged in DNA binding (5). It would be possible to envision a mechanism by which DNA binding could contribute to retaining DBP1 in the nucleus. Then, 14-3-3 G interaction might displace DBP1 from its target DNA sequence by binding to DBP1 at an overlapping site, thereby promoting DBP1 nuclear export. del1 construct lacks the C-terminal half of the DNC motif and still binds 


\section{Tobacco DBP1-interacting Proteins}

14-3-3 G. To definitely exclude the implication of the DNC motif in the interaction with 14-3-3 G, we tested the effect of point mutations in conserved positions of the remaining part of this motif, again in the context of the full-length DBP1 protein. Simultaneously introducing alanine substitutions P83A, R86A, and $587 \mathrm{~A}$ was previously shown to interfere with DNA recognition in vitro (5). However, these point mutations did not affect 14-3-3 $\mathrm{G}$ binding in the two-hybrid system (Fig. 2C, DBP1-mut1). Altogether, these results delimitate the interaction site to a 19 -amino acid stretch comprised between positions 64 and 82 .

14-3-3 Modulates DBP1 Nucleocytoplasmic Shuttling in VivoDBP1 was shown to be targeted to the nucleus in yeast using an in vivo nuclear import assay (3). The C-terminal half of the protein was also efficiently imported into the nucleus, consistent with the location in this region of a putative bipartite nuclear localization signal. Nuclear targeting was studied in planta by analyzing the subcellular localization of translational fusions to GFP in transient expression assays as driven by the $35 \mathrm{~S}$ constitutive promoter upon infiltration of tobacco leaves with $A$. tumefaciens carrying the relevant gene construct (agroinfiltration) and subsequent detection of green fluorescence by confocal laser scanning microscopy. Both the fulllength protein (GFP-DBP1) and the C-terminal half of DBP1 (GFP-DBP1Ct $)$ were found distributed both in the cytosol and in the nucleus (Fig. $3 A$, left panels). This dual localization was also observed for GFP when expressed alone and is in agreement with previous observations (20). However, whereas GFP nucleocytoplasmic distribution may be explained by diffusion of such a small protein as GFP through the nuclear membrane, the presence of the GFP-DBP1 and GFP-DBP1Ct fusions in the nucleus of transformed plant cells suggests an active nuclear import mechanism, because the size of the fusion protein is beyond the size exclusion limit of the nuclear pore complex (21). This would be consistent with a possible dual function of DBP1 in different subcellular compartments.

One of the reported functions of 14-3-3 proteins is the modulation of subcellular localization of their target proteins (22). As shown in Fig. $3 A$ (right panels), co-expression of 14-3-3 G clearly excluded full-length DBP1 (GFP-DBPI) from the nucleus, whereas the subcellular localization of GFP alone remained unaltered under the same conditions. As expected, a truncated DBP1 protein lacking the N-terminal region (GFP$D B P 1 C t$ ), and therefore unable to interact with 14-3-3 G, retains its nucleocytoplasmic distribution even when co-expressed with 14-3-3 G (Fig. $3 A$, night bottom panel). These results provide strong evidence for modulation of DBP1 nucleocytoplasmic partitioning via a direct interaction with 14-3-3 G through the N-terminal region. As discussed above, because this region is also involved in DNA recognition, 14-3-3 G might promote DBP1 nuclear export by interfering with DNA binding. Although we have excluded the direct implication of the DNC DBP1 DNA binding motif in the interaction with 14-3-3 $\mathrm{G}$, the site for this interaction lies adjacent to the DNC motif, making it still possible to compromise binding to DNA. However, DNA binding seems not to directly contribute to DBP1 nuclear localization because the aforementioned mutations in DBP-mut1, which abolished DNA binding in vitro (5), did not

$\mathbf{A}$

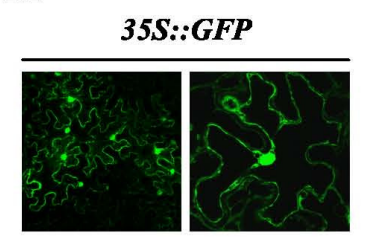

35S::GFP:DBP1

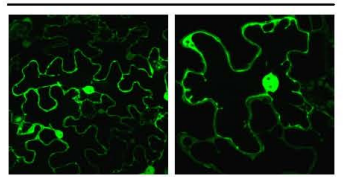

35S::GFP:DBP1Ct

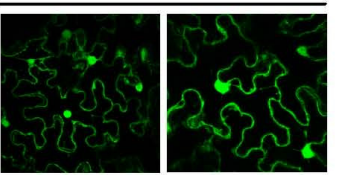

B

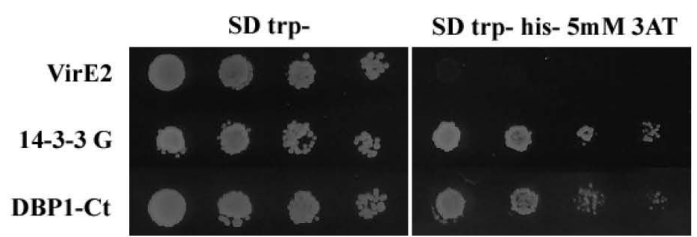

FIGURE 3. Subcellular localization of DBP1. $A, D B P 1$ subcellular localization as revealed by transient expression of a translational GFP-DBP1 fusion in $N$. benthamiana leaves. Above the images, the relevant infiltrated constructs are indicated. $B, 14-3-3$ G nuclear targeting in yeast. Nuclear localization results in expression of the HIS3 reporter gene and yeast growth on medium lacking histidine and supplemented with 3AT. VirE2 is a protein from A. tumefaciens used as a negative control because of its reported cytoplasmic localization. DBP1-Ct refers to the C-terminal half of DBP1, which contains a putative bipartite nuclear localization signal and was previously shown to be efficiently imported into the yeast nucleus.

affect DBP1 nuclear accumulation in transient expression assays (data not shown)

$14-3-3$ 's have been shown to regulate the nucleocytoplasmic shuttling of human histone deacetylases $(23,24)$, of Xenopus protein phosphatase Cdc 25 , (25), and of p27, a cyclin-dependent kinase inhibitor (26). 14-3-3 proteins often promote the cytoplasmic accumulation of their partners, but also nuclear targeting in others $(27,28)$. In plants, direct evidence for such a role of 14-3-3 proteins is scant. For example, the tobacco transcription factor RSG is in charge of controlling the biosynthetic pathway of gibberellic acid (GA) and shows a GA-regulated nucleocytoplasmic shuttling. A mutant version of RSG not able to interact with its 14-3-3 ligand fails to shuttle and accumulates predominantly in the nucleus even in the presence of gibberellic acid $(29,30)$. In this regard, we offer further direct evidence, based on both loss- and gain-of-function experiments, 
A
Detachment (h)

$\begin{array}{lll}0 & 6 & 24\end{array}$

CEVII

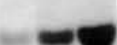

DBP1

$14-3-3 G$

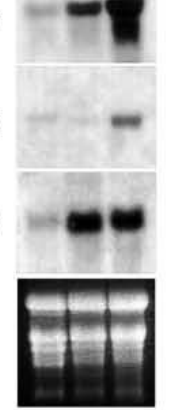

C

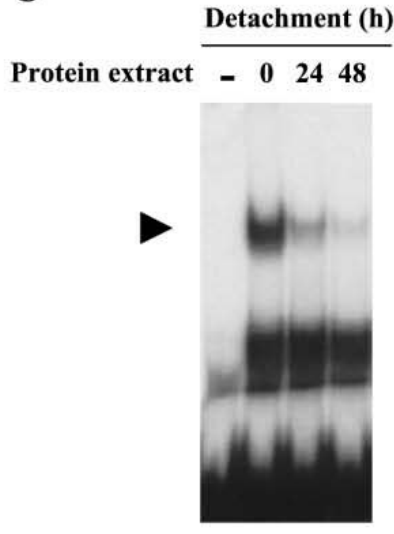

D

B

\begin{tabular}{|l|c|c|c|}
\hline \multirow{2}{*}{} & \multicolumn{3}{|c|}{ Detachment (h) } \\
\cline { 2 - 4 } & 0 & 6 & 24 \\
\hline $\begin{array}{l}\text { Cells showing } \\
\text { observable DBP1 } \\
\text { nuclear accumulation } \\
\text { (\%) }\end{array}$ & $80-90$ & $50-60$ & $20-25$ \\
\hline
\end{tabular}

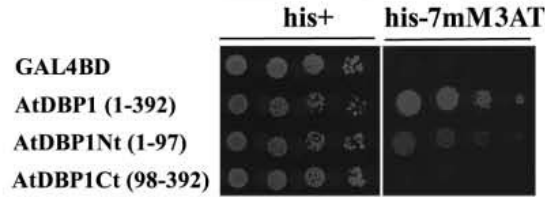

FIGURE 4. Functional modulation of DBP1 by 14-3-3 G. A, gene expression in response to detachment Tobacco leaf disks were floated on $20 \mathrm{mmHepes}-\mathrm{KOH}, \mathrm{pH} \mathrm{6.9}$, for the indicated times. $20 \mu \mathrm{g}$ of total RNA was loaded per lane, transferred to nylon membranes, and hybridized to ${ }^{32} \mathrm{P}$-labeled probes. Ethidium bromide staining of RNA is shown at the bottom as indicative of loading. $B$, subcellular distribution during detachment of the fusion protein GFP-DBP1 transiently expressed in leaves of $N$. bent ham iana. In the table, the per centage of cells showing nuclear localization of the fusion protein among those cells displaying GFP-derived fluorescence is indicated. The figures are derived from three independent agroinfiltration experiments. $C$, analysis of DBP1 DNA binding in vitro by electrophoretic mobility shift assay. Briefly, a radiolabeled 3 a 4 fragment derived from the CEV/II promoter was used as a probe and combined with proten extracts prepared from derive from the CEVII promoter was used as a probe and combined with protein extr acts prepar ed from detached tobacco leaf disks. D, inter action of Rrabidopsis $A$ tDBPI with GRFF $(14-3-3 \lambda)$. Serial dilutions of yeast cul ture containing ( $($ eft) and histidine-lacking medium supplemented with $7 \mathrm{~mm} 3 \mathrm{AT}$ (right). GAL 4BD-AtDBPINt, N-terminal region of AtDBP1; GALABD-AtD BP ICt, AtDBP1 protein excluding the $\mathrm{N}$-terminal region

that a 14-3-3 protein also regulates the nucleocytoplasmic distribution of DBP1.

To complement these studies, and by means of using a yeast nuclear import system (9), we set out to test whether the tobacco 14-3-3 isoform $\mathrm{G}$ was intrinsically competent to enter the nucleus as a prerequisite to function in the observed shuttling of the client DBP1 protein. As shown in Fig. 3B, 14-3-3 isoform $\mathrm{G}$ is very efficiently imported into the yeast nucleus. VirE2, a protein from A.tumefaciens, is here used as a negative control based on its reported cytosolic localization (9). The C-terminal half ofDBP1, previously shown to be targeted to the nucleus with high efficiency (3), was included in the assay as a positive control. This result is in agreement with the work by Paul et al. (31), who have very recently found $14-3-3 \kappa$ and $\lambda$, the closest Arabidopsis relatives of 14-3-3 G, to be predominantly localized in the nucleus.

14-3-3 G Expression Is Induced in Detached Leaf Sectors and Precedes CEVI1 Gene Activation-Under resting conditions DBP1 represses transcription of $C E V 11$ by binding to a $3 a 4$ cis element located in the $5^{\prime}$-promoter region of $C E V 1$ (3). Excision of leaf sectors from the plant results in loss of DBP1 bind-
Tobacco DBP1-interacting Proteins

ing to the $3 a 4$ element and the concomitant induction of $C E V I 1$ gene expression in the detached leaf tissue (3). Thus, we reasoned that if 14-3-3 $\mathrm{G}$ is involved in relieving CEVI1 transcriptional repression mediated by DBP1, inductive stimuli should prime the interaction of these two proteins and thereby the export and exclusion of DBP1 from the nucleus. A simple model would imply a rapid induction of $14-3-3 \mathrm{G}$ gene expression under inductive conditions, preceding that of the CEVII gene. As discussed above, de novo synthesized 14-3-3 G would be targeted to the nucleus, where it would interact with DBP1, leading to nuclear export. To test this hypothesis, we analyzed the expression of CEVI1, DBP1, and 14-3-3 G genes by Northern hybridization (Fig. $4 A$ ). Tobacco leaf disks were excised and allowed to float on Hepes buffer as already described (4). Both CEVI and $14-3-3 G$ were induced after leaf detachment but with different kinetics. Whereas 14-3-3 G mRNA showed a maximal level of accumulation as early as $6 \mathrm{~h}$ after detachment, CEVI I mRNA continued to accumulate until 24 h. $D B P 1$ expression was low and intriguingly was up-regulated at late times during detachment, after being slightly reduced at short times. A plausible explanation for this late induction might be the need for resetting the DBP1-mediated regulatory mechanism, although we cannot rule out the possibility that DBP1 plays additional roles in the detachment response. To validate the proposed model in vivo, we detached leaf tissue and monitored the effect on the subcellular partitioning of a GFP-DBP1 fusion compared with a GFP control. The percentage of cells showing nuclear localization of the GFP-derived fluorescence with respect to the total number of cells expressing the fusion protein was estimated at 0,6 , and $24 \mathrm{~h}$ directly in the detached leaf disks. As shown in Fig. $4 B$, detachment results in a progressive and significant reduction in the number of cells where GFPDBP1 protein is detected in the nucleus, clearly indicating a shift in the nucleocytoplasmic balance of the protein in response to detachment, concomitant with CEVI1 gene activation. In contrast, distribution of GFP alone was not affected under the same conditions as the nucleocytoplasmic fluorescence ratio was maintained constant throughout the course of the experiment (data not shown). Interestingly, the observed subcellular relocalization of DBP1 tightly correlates with a progressive impairment of the DNA binding activity in crude protein extracts toward the 3a4 DNA probe as measured by gel 
Tobacco DBP1-interacting Proteins
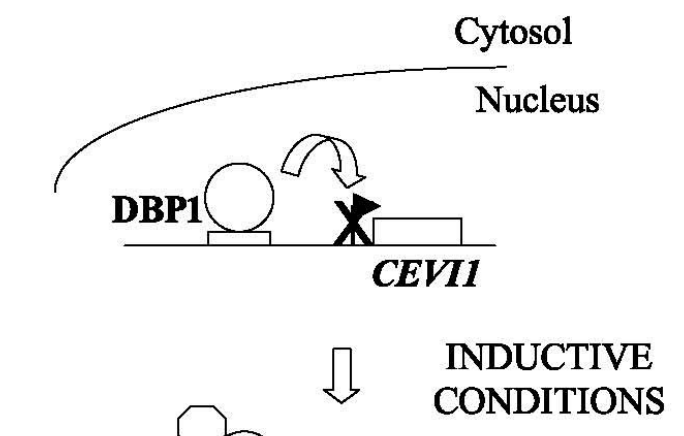

14-3-3G

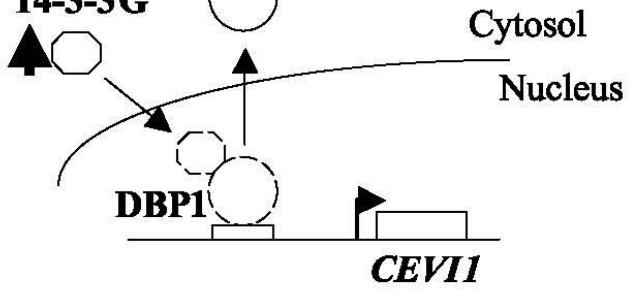

FIGURE 5. Proposed model for the regulation of CEVIT gene expression. Under resting conditions, DBP1 is bound to its target sequence in the CEV/1 promoter, repressing transcription. Upon detachment, and likely also after infection by a compatible viral pathogen, $14-3-3 \mathrm{G}$ expression is rapidly induced and the protein is imported into the nucleus and binds to DBP1, leading to promoter release. The DBP1-14-3-3 G complex is exported from the nucleus and retained in the cytoplasm, thereby releving DBP1-mediated repression of CEV/1 transcription. Dashed lines indicate a transient situation.

shift assays (Fig. 4C). Thus, upon induction, the retention of DBP1 in the cytoplasm prevents the protein from exerting its associated DNA binding activity.

Arabidopsis AtDBP1 Also Interacts with a 14-3-3 ProteinInterestingly, four genes encoding DBP1-related proteins have been identified in Arabidopsis (5), with AtDBP1 (At2g25620; GenBank $^{\mathrm{TM}}$ accession number NM_128120) showing the highest similarity to tobacco DBP1. Thus, we wondered whether AtDBP1 might also interact with a similar protein as that reported above for tobacco. To answer this question, we screened an Arabidopsis GAL4AD-cDNA library with the twohybrid system using AtDBP1 as bait. This screen resulted in the identification of several clones encoding 14-3-3 $\lambda$ (At5g10450, also referred to as GRF6; accession number NM_121083; Fig. 4D). 14-3-3 $\lambda$, as already mentioned, is one of the closest Arabidopsis relatives of 14-3-3 G and may thus represent the functional ortholog from Arabidopsis. In this case the interaction was also mediated through the $\mathrm{N}$-terminal region of AtDBP1, which appears again to be necessary and sufficient for the interaction to take place (Fig. $4 \mathrm{C}$ ). These results thus reinforce the biological significance of the interaction found between DBP1 and 14-3-3. Whether the different members of these two gene families are interchangeable and able to interact remains to be demonstrated.

In sum, all these observations favor the interpretation that 14-3-3 isoform G positively regulates CEVI1 gene induction in tobacco by a direct interaction with DBP1 and a subsequent nuclear export of the complex to the cytoplasm. Thus, we propose a model, depicted in Fig. 5, in which in healthy leaves DBP1 is bound to the CEVI1 promoter to repress transcription (3). Upon excision/detachment of leaf sectors, and very likely also in response to infection by a compatible viral pathogen, expression of 14-3-3 $G$ would be primed with the corresponding accumulation of the protein in the nucleus, where it interacts with DBP1. As a result of this interaction, the protein complex would be exported from the nucleus and sequester DBP1 in the cytoplasm, thereby preventing binding to the $C E V I I$ promoter and eventually relieving CEVII repression. Whether the sole interaction of DBP1 with 14-3-3 is sufficient to trigger this mechanism or alternatively requires additional partners, and also what other defense-related genes may be regulated in the same way, remain our challenges for the future.

Acknowledgments-We gratefully acknowledge P. James (University of Wisconsin, Madison) for providing yeast strains PJ69-4A and PJ69-4 $\alpha$, F. Boernke and U. Sonnewald (Institut für Pflanzengenetik und Kulturpflanzenforschung, Gatersleben, Germany) for the tobacco two-hybrid library, R. J. Ferl (University of Florida, Gainesville) for the antiserum against $A$. thaliana 14-3-3, P. Ouwerkerk (Leiden University, Leiden, The Netherlands) for the A. thaliana two-hybrid library and for helpful discussions, D. Gietz (University of Manitoba, Winnipeg, Canada) for invaluable advice in yeast transformation and the two-hybrid system, T. Tzfira and V. Citovsky (State University of New York, Stony Brook) for the yeast nuclear import system, V. Rubio and X. W. Deng (Yale University) for the $p V R$-GFP-Ct plasmid, and V. Ramirez for help in the use of the confocal microscope. We thank B. Wulff for comments on the manuscript.

\section{REFERENCES}

1. Malek, K., Levine, A., Eulgem, T., Morgan, A., Schmid, J., Lawton, K. A., Dangl, J. L., and Dietrich, R. A. (2000) Nat. Genet. 26, 403-410

2. Mahalingam, R., Gómez-Buitrago, A., Eckardt, N., Shah, N., GuevaraGarcía, A., Day, P., Raina, R., and Fedoroff, N. V. (2003) Genome Biol. 4, R20

3. Carrasco, J. L., Ancillo, G., Mayda, E., and Vera, P. (2003) EMBO J. 22, $3376-3384$

4. Mayda, E., Marqués, C., Conejero, V., and Vera, P. (2000) Mol. PlantMicrobe Interact. 13, 23-31

5. Carrasco, J. L., Ancillo, G., Castelló, M. J., and Vera, P.(2005) Plant Physiol. 137, 602-606

6. James, P., Halladay, J., and Craig, E. A. (1996) Genetics 144, 1425-1436

7. Gietz, R. D., Triggs-Raine, B., Robbins, A., Graham, K. C., and Woods, R. A. (1997) Mol. Cell Biochem. 172, 67-79

8. Soellick, T. R., and Uhrig, J. F. (2001) Genome Biol. 2, 00521-00527

9. Rhee, Y., Gurel, F., Gafni, Y., Dingwall, C., and Citovsky, V. (2000) Nat. Biotechnol. 18, 433-437

10. Tornero, P., Mayda, M., Gomez, M. D., Cañas, L., Conejero, V., and Vera, P. (1996) Plant J. 10, 315-330

11. Boernke, F. (2005) J. Plant Physiol. 162, 161-168

12. Fu, H., Subramanian, R. R., and Masters, S. C. (2000) Annu. Rev. Pharmacol. Toxicol, 40, 617-647

13. Aitken, A., Baxter, H., Dubois, T., Clokie, S., Mackie, S., Mitchell, K., Peden, A., and Zemlickova, E. (2002) Biochem. Soc. Trans. 30, 351-360

14. Roberts, M. R. (2003) Trends Plant Sci. 8, 218-223

15. Ferl, R. J. (2004) Physiol. Plant. 120, 173-178

16. de Vetten, N. C., Lu, G., and Ferl, R. J. (1992) Plant Cell 4, 1295-1307

17. Lu, G., DeLisle, A. J., de Vetten, N. C., and Ferl, R. J. (1992) Proc. Natl. Acad. Sci. U. S. A. 89, $11490-11494$

18. Pan, S., Sehnke, P. C., Ferl, R. J., and Gurley, W. B. (1999) Plant Cell 11, 1591-1602 


\section{Tobacco DBP1-interacting Proteins}

19. Yaffe, M. B., Rittinger, K., Volinia, S., Caron, P. R., Aitken, A., Leffers, H., Gamblin, S. J., Smerdon, S. J., and Cantley, L. C. (1997) Cell 91, 961-971

20. Coego, A., Ramírez, V., Gil, M. J., Flors, V., Mauch-Mani, B., and Vera, P. (2005) Plant Cell 17, 2123-2137

21. Kaffman, A., and O'Shea, E. K. (1999) Annu. Rev. Cell Dev. Biol 15, 291-339

22. Eckardt, N. A. (2001) Plant Cell 13, 2385-2389

23. Grozinger, C. M., and Schreiber, S. L. (2000) Proc. Natl. Acad. Sci. U. S. A. 97, 7835-7840

24. Zhao, X., Ito, A., Kane, C. D., Liao, T. S., Bolger, T. A., Lemrow, S. M., Means, A. R., and Yao, T. P. (2001) J. Biol. Chem. 276, 35042-35048

25. Kumagai, A., and Dunphy, W. G. (1999) Genes Dev. 13, 1067-1072
26. Sekimoto, T., Fukumoto, M., and Yoneda, Y. (2004) EMBO J. 23, $1934-1942$

27. Tang, S. J., Suen, T. C., McInnes, R. R., and Buchwald, M. (1998) J. Biol Chem. 273, 25356-25363

28. Seimiya, H., Sawada, H., Muramatsu, Y., Shimizu, M., Ohko, K., Yamane, K., and Tsuruo, T. (2000) EMBO J. 19, 2652-2661

29. Igarashi, D., Ishida, S., Fukazawa, J., and Takahashi, Y. (2001) Plant Cell 13, 2483-2497

30. Ishida, S., Fukazawa, J., Yuasa, T., and Takahashi, Y. (2004) Plant Cell 16, 2641-2651

31. Paul, A. L., Sehnke, P. C., and Ferl, R. J. (2005) Mol. Biol. Cell 16, $1735-1743$ 

CAPÍTULO 3 



\section{Early molecular events determining susceptibility to} potyvirus infection in Arabidopsis thaliana

María José Castelló, José Luis Carrasco and Pablo Vera

Instituto de Biología Molecular y Celular de Plantas, Universidad Politécnica de Valencia C.S.I.C., Ciudad Politécnica de la Innovación, edificio 8E, Ingeniero Fausto Elio, s/n, 46011 Valencia 
Translation initiation factor elF4E isoforms have been shown to mediate susceptibility to potyviruses, the largest group of plant viruses. Here we describe a physical interaction between elF(iso)4E and AtDBP1, a DNA-binding protein phosphatase from Arabidopsis thaliana. This interaction relies on a catalytically active protein phosphatase domain, suggesting that elF(iso)4E is a substrate of AtDBP1. Loss of AtDBP1 function leads to reduced elF(iso)4E protein accumulation and partial resistance to potyviruses. A model depicting the involvement of AtDBP1 in potyviral infection and showing regulation of elF(iso)4E protein accumulation through dephosphorylation is presented.

Virus infections are responsible for numerous plant diseases that cause worldwide losses in production and quality of vegetable and ornamental crops. In contrast to the response to bacterial or fungal pathogens, plant resistance to viral infections is largely a recessive genetic trait. Viruses are obligate parasites and rely on host factors to complete every stage of their infectious cycle; therefore, recessive resistance likely reflects absence or misfunction of a host factor that prevents the virus from multiplying and/or systemically moving inside the host (1).

DNA-binding protein phosphatase (DBP) factors form a recently described family of novel regulatory proteins featuring two functional domains that provide sequence-specific DNAbinding and protein phosphatase activity (2). Tobacco DBP1, the founding member of the family, has been shown to be directly engaged in the transcriptional regulation of a virusinduced gene (3). Four genes encoding DBP factors have been identified in the model species Arabidopsis thaliana, with AtDBP1 showing the highest sequence similarity to tobacco DBP1. To date, neither the molecular targets nor the processes these factors are involved in have been described.

We investigated the function of DBP factors in Arabidopsis using homozygous plants from the SALK collection (4) bearing a T-DNA insertion in the AtDBP1 gene that reduces gene expression to negligible levels (Fig. 1A). Loss of AtDBP1 function in this line (atdbp1), would be expected to alter gene expression and, eventually, protein accumulation of its targets. Indeed, proteome analysis of atdbp 1 plants revealed reduced expression of eIF(iso)4E, a plant-specific isoform of the translation initation factor elF4E, in comparison to Col-0 plants (data not shown). elF4E isoforms bind the cap structure present at the 5' end of eukaryotic mRNAs and promote recruitment of additional factors and $\mathrm{mRNA}$ circularization, thereby enabling translation initiation (5). This finding is important because elF4E and elF(iso)4E have been implicated as key factors in recessive resistance against potyviruses in many plant species (6). Potyviruses represent the largest and potentially the most economically destructive family of plant viruses. Western blot analysis using a specific polyclonal antiserum raised against Arabidopsis elF(iso)4E confirmed that the atdbp1 mutant line accumulated less of the eIF(iso)4E protein (Fig. 1B). A posttranscriptional regulatory mechanism could be involved because there was no difference in eIF(iso) $4 E$ gene expression between Col-0 and atdbp1 plants at the mRNA level as determined 
by RT-PCR using specific primers (Fig. 1C). This suggests a functional link between AtDBP1 and $\mathrm{elF}$ (iso)4E at the protein level and may indicate a direct interaction between these two proteins in the course of a potyviral infection. Using the yeast two-hybrid system, we demonstrated a specific physical interaction between AtDBP1 and elF(iso)4E (Fig. 1D). The interaction requires structural integrity of AtDBP1 and a functional protein phosphatase domain, and was confirmed in planta by coimmunoprecipitation (Fig. 1E). A similar result was reported for the physical interaction between the protein phosphatase $2 \mathrm{C} \mathrm{ABI1}$, involved in signalling of the plant hormone abscisic acid, and the homeodomain transcription factor AtHB6 (7). The ability of these proteins to interact was correlated with the PP2C activity of ABI1. Single point mutations in $A B I 1$ that reduced its enzymatic activity impaired the interaction with AtHB6. Similarly, elF(iso)4E might be a substrate of AtDBP1 dephosphorylating activity. Phosphorylation has been shown to play a critical role in the regulation of elF4E function in animal systems, where both the binding of the repressor elF4E-binding proteins and the function of elF4E itself are specifically modulated by phosphorylation in response to various stimuli (8-11), and also during viral infection (12). On the other hand, phosphorylation of both elF4E and elF(iso)4E alters their affinity for the cap structure both in animals and plants (12-14), although the implication of these modifications in protein translation is not clear. In fact, the extent of the contribution of phosphorylation/dephosphorylation to elF4E/elF(iso)4E regulation in plants and the mechanisms involved in this process are not well known $(15,16)$. Therefore, our results showing that $\mathrm{eIF}(\mathrm{iso}) 4 \mathrm{E}$ from Arabidopsis specifically interacts with the protein phosphatase AtDBP1 are especially relevant.

Mutations that abolish expression of elF(iso)4E have been reported to confer resistance to infection by potyviruses $(17,18)$, suggesting that this protein is required for the virus to successfully invade the plant. The potyvirus genome is a single-stranded polyA-tailed positive RNA genome that is expressed as a polyprotein and subsequently processed into functional proteins by viral proteases. The 5' end of the genomic RNA lacks a cap structure and instead is covalently bound to a virus-encoded protein termed VPg. In this viral scenario, elF4E isoforms play a critical role during the infection, but the process involved still requires elucidation. These isoforms have been shown to specifically interact with the VPg of specific potyviruses, and the ability of these proteins to interact correlates with virus infectivity (19). Therefore, impairment of this interaction might account for the resistance phenotype conferred by elF4E and elF(iso) $4 E$ mutations. Since eiF(iso)4E protein accumulation is reduced in atdbp1, we reasoned that this mutant could also be at least partially resistant to potyvirus. To test this hypothesis, Col-0 and atdbp1 plants were inoculated with a GFP-tagged version of Plum pox potyvirus (PPV) via agroinfiltration. Viral accumulation was first analyzed at the RNA level using quantitative RTPCR with specific primers. Results showed a delay in amplification of a GFP-derived product from total RNA isolated from systemic non-inoculated atdbp1 leaves $20 \mathrm{~d}$ after inoculation (Fig.2A), reflecting a roughly 40 -fold lower accumulation of viral RNA in the mutant. This observation was further confirmed by Western blot at the protein level by analyzing GFP protein 
accumulation in systemic leaves of both genotypes. As shown in Fig. 2B, GFP accumulation was lower in systemic leaves of the atdbp1 mutant $20 \mathrm{~d}$ after inoculation. Furthermore, inspection of GFP distribution by fluorescence microscopy revealed that viral spread was delayed in the atdbp1 mutant (Fig. 2C). In Col-0 plants, the virus accumulated in the vascular tissue of the inoculated leaf and moved through the petiole faster than in atdbp1 plants. Moreover, non-inoculated leaves that were already severely infected in Col-0 plants showed only incipient spread of the virus in atdbp1 plants at every time point after inoculation. At later time points, leaves of atdbp1 plants showed reduced viral accumulation. Therefore, the resistance displayed by atdbp1 plants was only partial while a null elF(iso) $4 E$ mutant $(17,18$, 20) completely precluded viral accumulation even in the inoculated leaf. These results suggest that $A t D B P 1$ gene function may be required for successful progression of PPV infection, either through a direct contribution to viral replication and/or movement or by repressing an antiviral defence pathway. At this time we cannot say to what extent translation and replication of the viral genome, as well as cell-to-cell and long-distance movement of viral particles is affected by the absence of AtDBP1 function. However, we believe that the role of AtDBP1 during viral infection involves, at least partly, interaction with elF(iso)4E. Symptoms induced by PPV infection in Arabidopsis show high variability among different accessions and also within specific susceptible ecotypes, such as Col-0 (20). In this interaction, correlation analysis showed weak linearity beween symptom severity and virus accumulation, which both seem to be polygenic and quantitative traits (21). We also analyzed the performance of atdbp1 plants against another potyvirus, Turnip Mosaic Virus (TuMV), which causes more severe symptoms in Col-0 than PPV infection. We found significant variability in symptom development among different plants within the same genotype. However, both vegetative and inflorescence tissue in atdbp1 plants were again less affected by TuMV infection than in Col-0 plants (Fig. 3A).These results further suggest the biological relevance of the role that AtDBP1 function may play during potyvirus infection.

The reduced elF(iso)4E protein accumulation observed in the absence of AtDBP1 function prompted us to wonder if dephosphorylation by AtDBP1 could stabilize eIF(iso)4E and prevent its degradation via the proteasome. To test this, we analyzed the effect of the proteasome inhibitor MG-132 on elF(iso)4E protein accumulation in both a Col-0 and an atdbp1 mutant background. Western blot analysis confirmed that proteasome inhibition led to an increase in the amount of elF(iso)4E protein in atdbp1 but not in Col-0 (Fig. 3B). Therefore, when AtDBP1 function is lacking, elF(iso)4E is less stable, likely as a consequence of the prevalence of the phosphorylated isoform in the absence of AtDBP1 dephosphorylating activity. Our results have important implications in terms of elF(iso)4E function and potyviral infection and provide the first evidence for a phosphorylation-dependent, proteasome-mediated regulation of elF(iso) $4 \mathrm{E}$ and its role in potyvirus resistance. Figure 4 presents a model depicting a regulatory mechanism that eventually determines the outcome of the viral infection. Since a lack of AtDBP1 function results in reduced accumulation of elF(iso)4E, we propose that 
dephosphorylation by AtDBP1 stabilizes elF(iso)4E, thereby enhancing the potential for interaction with VPg. In fact, as shown in Fig. 3C, elF(iso)4E protein accumulation increased in both inoculated and systemic leaves after PPV infection. This was particularly evident in noninoculated leaves, where the virus extensively invaded the leaf tissue, as opposed to the inoculated leaf where the virus accumulated only in the major vascular bundle. In contrast, the level of mRNA remained invariant (data not shown).

Interestingly, it was recently reported that human elF4E undergoes selective ubiquitination and proteasome-mediated degradation, likely associated with stress responses $(22,23)$. In our model, we propose that potyvirus infection promoted AtDBP1-elF(iso)4E interaction and led to increased elF(iso)4E accumulation. Hence, the translation initiation factor is dephosphorylated and stabilized, leading to susceptibility. In contrast, perturbing AtDBP1 function would hamper the elF(iso)4E-VPg interaction and impair successful progression of the infection because of a relative increase in the level of phosphorylated elF(iso)4E, which would be less stable. Thus, down-regulating AtDBP1 function may represent a novel strategy for engineering potyviral-resistant plants. 


\section{Figure 1}

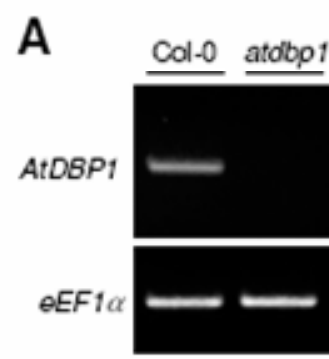

B
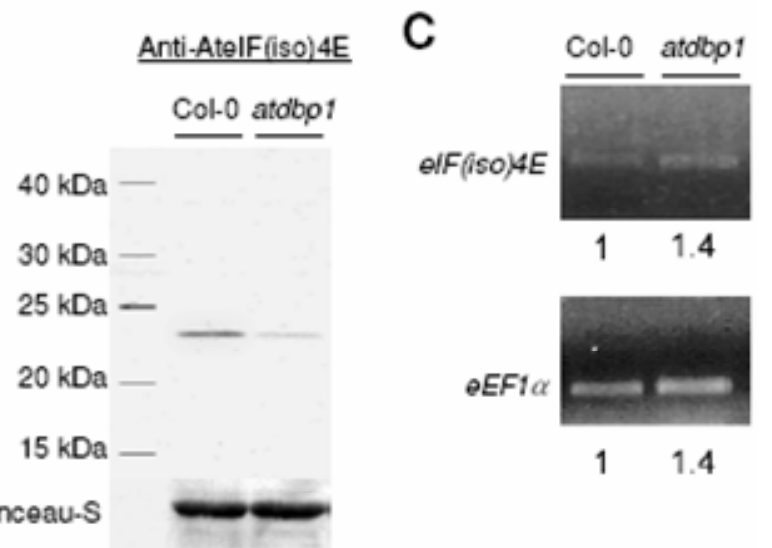

D

GAL4AD-AteIF(iso)4E

GAL4BD

GAL4BD-ATDBP1

GAL4BD-ATDBP1Nt

GAL4BD-AtDBP1Phos

GAL4BD-ATDBP1-R2

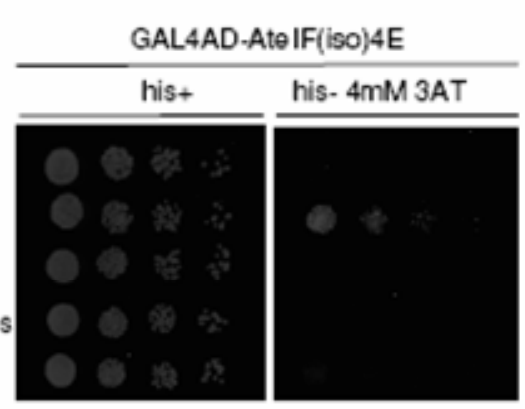

E

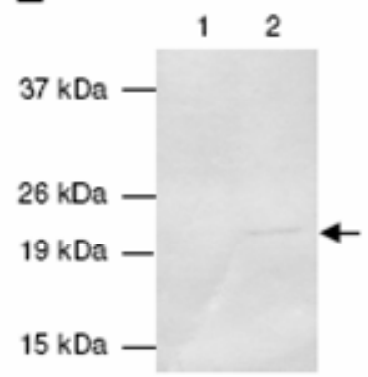

Fig. 1. (A) AtDBP1 gene expression in the atdbp1 line and interaction with elF(iso)4E. Semiquantitative RT-PCR analysis of AtDBP1 mRNA accumulation in Col-0 and homozygous atdbp1 plants. RT-PCR amplification of the housekeeping gene eEF1a is shown below as control of RNA loading. (B) Western blot of leaf protein extracts using a polyclonal antiserum raised against AtelF(iso)4E. Molecular marker band size is indicated on the left. As a loading control, the Ponceau-S staining of the membrane after transfer is shown at the bottom. (C) RTPCR analysis of the accumulation of AtelF(iso)4E and AteEF1a mRNA in Col-0 and atdbp1 plants. (D, E) Analysis of the interaction between AtDBP1 and AtelF(iso)4E. (D) Growth of yeast expressing AtDBP1 fusions to GAL4BD and GAL4AD-AtelF(iso)4E in the presence (left) and in the absence (right) of histidine. 3AT (3-aminotriazol) is a competitive inhibitor of HIS3. (E) Coimmunoprecipitation of AtDBP1 and AtelF(iso)4E: Protein extracts from wild type plants (1) and plants expressing AtDBP1 fused to the hemaglutinin epitope (HA) (2) were immunoprecipitated with a polyclonal antiserum against HA. A Western blot of the immunoprecipitated fractions immunodecorated with an anti-AtelF(iso)4E antiserum is shown. 


\section{Figure 2}

A

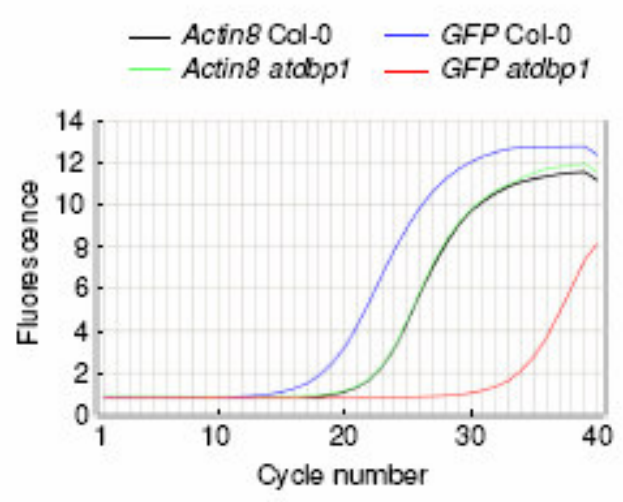

C

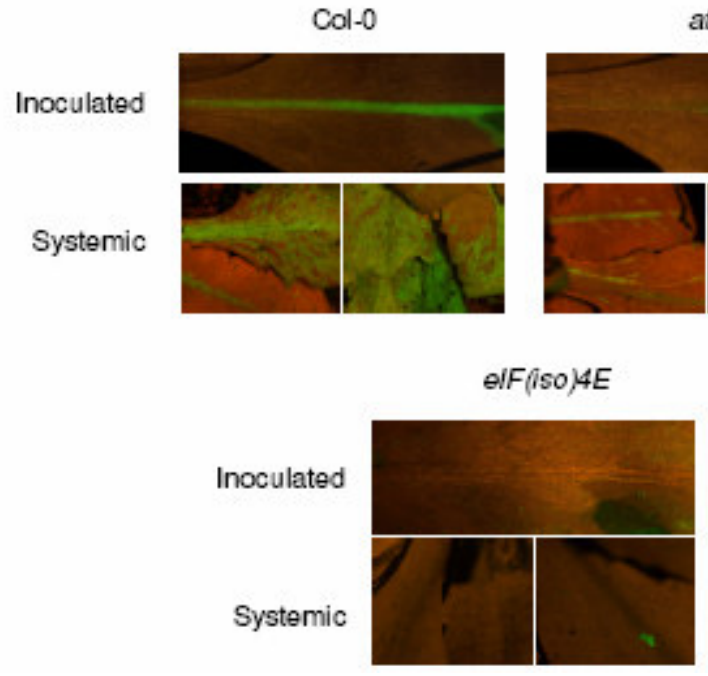

B

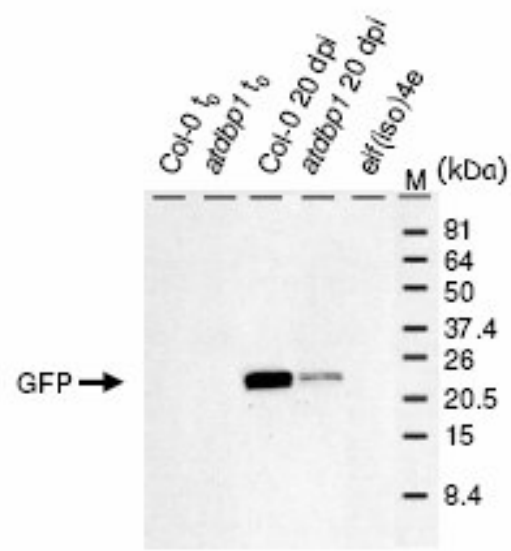

atolbo 1

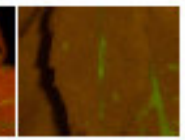

Fig. 2. atdbp1 loss-of-function mutant shows partial resistance to potyvirus infection. (A) Analysis of viral RNA accumulation in Col-0 and atdbp1 plants after inoculation with a GFPtagged version of Plum Pox Virus (PPV). Total RNA from systemic non-inoculated leaves was analyzed $20 \mathrm{~d}$ after inoculation by quantitative RT-PCR using primers specific for the GFP gene. ACTIN8 expression was used as a control. Data from a single assay are shown out of three independent experiments performed with similar results. (B) PPV-derived protein accumulation. Western blot of leaf protein extracts before inoculation $\left(\mathrm{t}_{0}\right)$ and from non-inoculated leaves $20 \mathrm{~d}$ after inoculation $\left(\mathrm{t}_{20}\right)$, immunodecorated with a polyclonal antiserum against GFP. Migration of molecular mass markers is indicated on the right. (C) Analysis of viral spread in inoculated and systemic leaves of Col-0, atdbp 1 and elF(iso) $4 E$ mutant plants by fluorescence microscopy for GFP detection. 


\section{Figure 3}

A

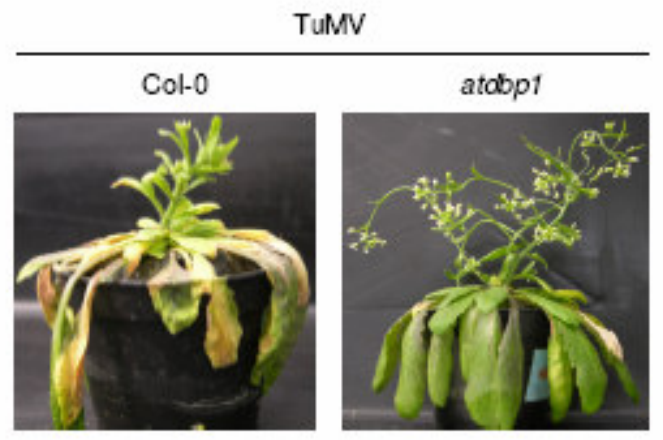

B

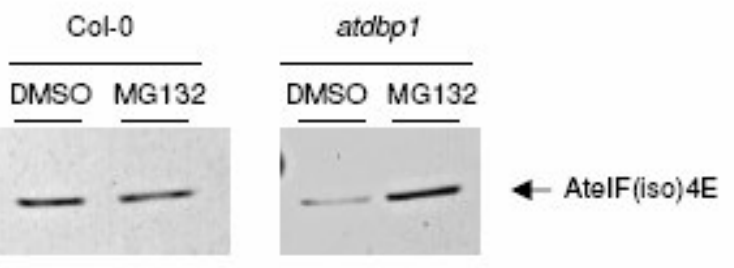

C

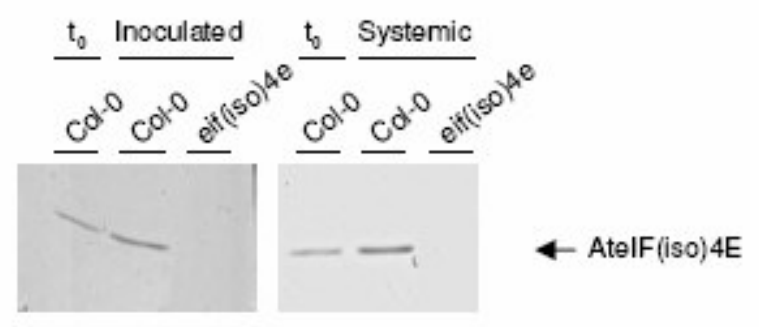

Fig. 3. (A). Symptom development $16 \mathrm{~d}$ after TuMV infection. (B) Western blot using a polyclonal antiserum against Arabidopsis eIF(iso)4E of protein extracts prepared from leaves immersed for $3 \mathrm{~h}$ with gentle agitation in $1 \mathrm{x}$ MS medium containing $100 \mu \mathrm{M}$ MG-132. As a control the same amount of the MG-132 solvent (DMSO) was added. (C) Western blot using a polyclonal antiserum against Arabidopsis elF(iso)4E of protein extracts prepared from inoculated and non-inoculated systemic leaves before and after PPV infection. 


\section{Figure 4}

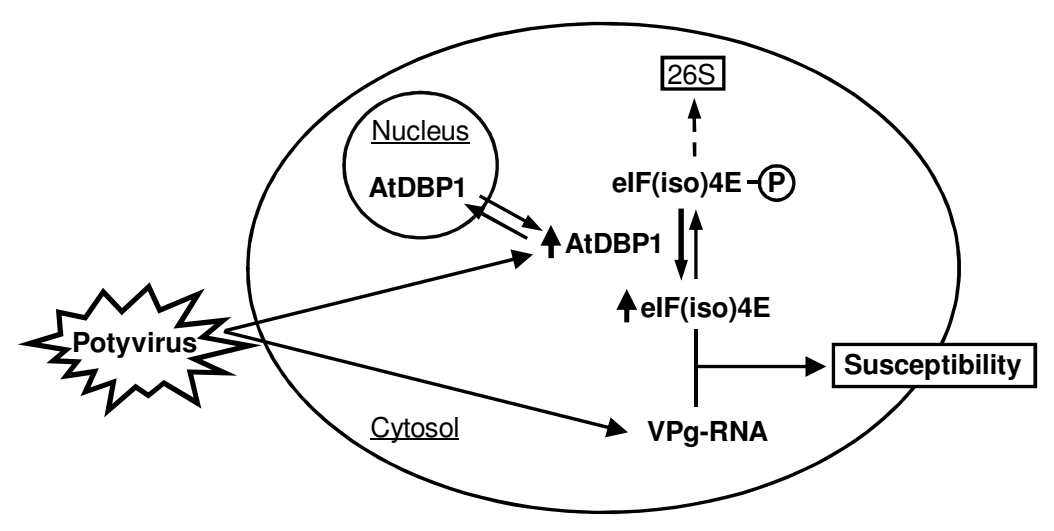

Fig. 4. A model for the AtDBP1-mediated molecular mechanism of the partial resistance to potyvirus infection shown by the AtDBP1 insertion line atdbp1. In wild type plants, potyvirus infection would promote AtDBP1-elF(iso)4E interaction, thereby increasing the dephosphorylation rate of AteIF(iso)4E and preventing its degradation by the proteasome. As a result, AteIF(iso)4E would accumulate at a higher level, enabling interaction with viral VPg and hence successful spread of the virus. The absence of AtDBP1 function would promote the accumulation of the phosphorylated form of AtelF(iso)4E, a better substrate for proteasomedependent degradation, resulting in a decrease in the steady-state level of AtelF(iso)4E and the restriction of viral infection. 


\section{REFERENCES}

1. J. A. Díaz-Pendón, V. Truniger, C. Nieto, J. García-Mas, A. Bendahmane, M. A. Aranda, Mol. Plant Pathol. 5, 223 (2004).

2. J. L. Carrasco, G. Ancillo, M. J. Castelló, P. Vera, Plant Physiol. 137, 602 (2005).

3. J. L. Carrasco, G. Ancillo, E. Mayda, P. Vera, EMBO J. 22, 3376 (2003).

4. J. M. Alonso et al. Science 301, 653 (2003).

5. K. S. Browning, Biochem. Soc. Trans. 32, 589 (2004).

6. C. Robaglia, C. Caranta. Trends Plant Sci. 11, 40 (2006).

7. A. Himmelbach, T. Hoffmann, M. Leube, B. Höhener, E. Grill, EMBO J. 21, 3029 (2002).

8. T. P. Herbert, A. R. Tee, C. G. Proud, C.G., J. Biol. Chem. 277, 11591 (2002).

9. A. C. Gingras, Y. Svitkin, G. J. Belsham, A. Pause, N. Sonenberg, Proc. Natl. Acad. Sci. USA 93, 5578 (1996).

10. A. C. Gingras, N. Sonenberg, Virology 237, 182 (1997).

11. G. C. Scheper, C. G. Proud, Eur. J. Biochem. 269, 5350 (2002).

12. M. Kleijn, C. L. J. Vrins, H. O. Voorma, H.O., A. A. M. Thomas, Virology 217, 486 (1996).

13. N. Sonenberg, A. C. Gingras, Curr. Opin. Cell Biol. 10, 268 (1998).

14. M. A. Khan, D. J. Goss, Biochemistry 43, 9092 (2004).

15. D. R. Gallie, H. Le, C. Caldwell, R. L. Tanguay, N. X. Hoang, K. S. Browning, J. Biol. Chem. 272, 1046 (1997).

16. S. Manjunath, A. J. Williams, J. Bailey-Serres, Plant J. 19, 21 (1999).

17. A. Duprat, C. Caranta, F. Revers, B. Menand, K. S. Browning, C. Robaglia, Plant J. 32, 927 (2002).

18. A. D. Lellis, K. D. Kasschau, S. A. Whitham, J. C. Carrington, Curr. Biol. 12, 1046 (2002).

19. S. Léonard, D. Plante, S. Wittmann, N. Daigneault, M. G. Fortin, J. F. Laliberte, J. Virol. 74, 7730 (2000).

20. V. Decroocq, O. Sicard, J. M. Alamillo, M. Lansac, J. P. Eyquard, J. A. García, T. Candresse, O. Le Gall, F. Revers. Mol. Plant-Microbe Int. 19, 541 (2006). 
21. O. Sicard, O. Loudet, J. J. B. Keurentjes, T. Candresse, O. Le Gall, F. Revers, V. Decroocq. Mol. Plant-Microbe Int. 21, 198 (2008).

22. T. Murata, K. Shimotohno, J. Biol. Chem. 281, 20788 (2006).

23. S. Othumpangat, M. Kashon, P. Joseph, J. Biol. Chem. 280, 25162 (2005).

24. We gratefully acknowledge the contribution of Sami Irar and Montserrat Pagès (Instituto de Biología Molecular de Barcelona, Spain), who provide the resources and the expertise for the comparative proteome analysis. We also thank Karen Browning (University of Texas, Austin, Texas) for kindly providing us with antisera, Christophe Robaglia (Université de la Méditerranée, Marseille, France) for the elF(iso)4E mutant, Juan Antonio García (Centro Nacional de Biotecnología, Madrid, Spain) for PPV strains, Fernando Ponz (Instituto Nacional de Investigación y Tecnología Agraria, Madrid, Spain) and Andrew Maule (John Innes Center, Norwich, UK) for TuMV infectious clones, Wei Shen and Linda Hanley-Bowdoin (North Carolina State University, Raleigh, North Carolina) for their help and advice in the proteasome inhibition assays, and Ana López for critical reading of the manuscript. 



\section{DISCUSIÓN GENERAL}





\section{DISCUSIÓN GENERAL}

En la presente tesis doctoral se ha abordado la caracterización genética, molecular y funcional de una nueva familia de reguladores transcripcionales denominados DBP (ㅁNAbinding protein-phosphatases), así como la contribución de uno de los miembros de dicha familia, el regulador AtDBP1 de Arabidopsis thaliana, a la respuesta defensiva de la planta frente a situaciones de estrés biótico.

El análisis funcional del promotor del gen CEVI1 (Mayda et al., 2000) permitió la identificación de un promotor mínimo responsable de la regulación transcripcional del gen (conocido como fragmento 3a4), así como el aislamiento de un nuevo factor de transcripción de tabaco (Nicotiana tabacum) denominado DBP1 (ㅁNA-Binding protein phosphatase 1). Dicho factor de transcripción se une de forma específica al promotor de CEVI1 en condiciones no inductivas, actuando muy probablemente como represor de la expresión del gen (Carrasco et al., 2003). DBP1 representa una nueva clase de reguladores transcripcionales que, además de poseer capacidad de unión al ADN específica de secuencia, presenta actividad proteínfosfatasa de tipo $2 \mathrm{C}$ localizada en su dominio $\mathrm{C}$-terminal. La búsqueda en bases de datos de genes con estructura similar, es decir que codificaran proteín-fosfatasas $2 \mathrm{C}$ con un dominio $\mathrm{N}$ terminal que mostrara homología al de DBP1, puso de manifiesto que DBP1 es el primer representante de una nueva familia de factores reguladores exclusivos de plantas.

Con el propósito de asignar una función al dominio N-terminal de la proteína DBP1, ya que no mostraba similitud significativa con dominios funcionales conocidos, realizamos ensayos de unión al ADN in vitro usando como sonda el fragmento 3a4 derivado del promotor del gen CEVI1. Los resultados obtenidos pusieron de manifiesto que la capacidad de unión al ADN que presenta DBP1 reside en su dominio $\mathrm{N}$-terminal. De los análisis realizados a partir de la comparación de secuencia de dicha región de la proteína con otros factores DBP de diferentes especies de plantas, comprobamos la existencia de un motivo altamente conservado en todas las proteínas DBP analizadas, tanto de especies de plantas monocotiledóneas como dicotiledóneas. Ensayos de movilidad electroforética (EMSA) con proteínas recombinantes portadoras de mutaciones en posiciones conservadas dentro de dicho motivo, revelaron su participación directa en la unión al ADN. En base a estos datos se denominó a este motivo DNC ( $\underline{D} B P \underline{N}$-terminal $\underline{c}$ rere). Nuestros resultados contribuyen así al descubrimiento de un nuevo motivo de secuencia, no descrito hasta el momento, implicado en interacciones proteínaADN. La conservación de este motivo entre los factores DBP de diferentes plantas parece indicar que el mecanismo que dirige la capacidad intrínseca de unión al ADN sería similar entre los diferentes miembros de la familia.

Con el objetivo de conocer el mecanismo que subyace a la función reguladora del factor DBP1 y las vías de señalización en las cuales pueden estar implicados estos nuevos factores, llevamos a cabo un rastreo mediante el sistema de doble híbrido de levadura de una 
genoteca de tabaco para identificar factores proteicos que interaccionan con dicho factor. Esta aproximación experimental permitió establecer una relación directa entre DBP1 y la isoforma G de la proteína 14-3-3.

Las 14-3-3 son una familia altamente conservada y ubicua de moléculas homo- y heterodiméricas presentes abundantemente en todas las células eucarióticas (Aitken, 1996). Son un grupo de proteínas multifuncionales con la capacidad de unirse y regular la función de un amplio rango de proteínas celulares. Por tanto, a través de su interacción con otras proteínas, las 14-3-3 participan en la regulación de diversos procesos biológicos. Además, varios estudios han implicado a las 14-3-3 como reguladores claves de sucesos de transducción de señal. Como ejemplo de ello podemos citar su implicación en la regulación de la entrada en el ciclo celular a través de su interacción con la proteín fosfatasa Cdc25C (Peng et al., 1997) o en la prevención de la apoptosis (Zha et al., 1996). Las 14-3-3 participan en la transducción de señal mediante la unión de proteínas que contienen residuos de serina fosforilados. Existen bastantes ejemplos en la bibliografía que demuestran que la interacción con 14-3-3 depende de fosforilación, implicando como elementos clave de dicha interacción a sitios de unión que contengan motivos de fosfoserina en los ligandos de dichas proteínas (Muslin et al, 1996). A pesar del alto grado de conservación de los sitios de fosfoserina y de las evidencias de que las 14-3-3 funcionan como dímeros, existen algunas evidencias que revelan que no todas las 14-3-3 requieren unión mediada por fosfoserina o dimerización (Aitken et al., 2002), lo que sugiere que las 14-3-3 deben tener más de un modo estándar de acción.

En un sentido amplio, las proteínas 14-3-3 pueden actuar como cofactores para modular la actividad catalítica o el estado conformacional de sus efectores. También pueden actuar como reguladores para prevenir la interacción de sus ligandos con otros componentes celulares, desencadenando una modificación en la localización intracelular, o impidiendo la formación de un complejo. Por otra parte pueden actuar como proteínas adaptadoras para inducir asociaciones entre proteínas gracias a la capacidad que presenta el dímero de 14-3-3 para unir dos ligandos; y también pueden secuestrar a sus proteínas de unión en el citosol inhibiendo así su función (Fu et al., 2000).

En las plantas, las 14-3-3 afectan a la actividad de varios enzimas y canales de iones. Ejemplos de ello son el caso de la nitrato reductasa y la bomba de protones de la membrana plasmática ATPasa, las cuales son inhibidas y activadas por 14-3-3 respectivamente (Huber et al., 2002; Comparot et al., 2003; Bunney et al., 2002). A su vez, en el reino vegetal, estas proteínas también han sido implicadas en el desarrollo de la planta y en la defensa frente a patógenos (Roberts, 2003).

El análisis por doble híbrido de deleciones y versiones mutadas de DBP1 reveló que la interacción entre ambas proteínas se restringe a un motivo del dominio $\mathrm{N}$-terminal adyacente al motivo DNC, sin estar éste último implicado en dicha interacción. Debido a la proximidad del sitio de interacción de la 14-3-3 G con el motivo DNC de unión a ADN de DBP1, era razonable considerar si la 14-3-3 G podía interferir en la unión al ADN de la proteína. La interacción con la 
14-3-3 podría así desplazar a DBP1 de su secuencia diana de ADN, promoviendo posiblemente una exportación nuclear del factor regulador. Además se ha descrito que determinadas isoformas de 14-3-3 regulan la localización subcelular de las proteínas diana con las que interaccionan, promoviendo su importación o exportación nuclear (Eckardt, 2001). Por todo ello, nos planteamos comprobar si la interacción con 14-3-3 G alteraba la localización subcelular de DBP1. La expresión transitoria en hojas de tabaco mediante infiltración de $A$. tumefaciens de fusiones traduccionales de DBP1 a la proteína fluorescente verde (GFP), nos permitió demostrar que DBP1 se reparte entre núcleo y citoplasma en condiciones de reposo, lo que podría indicar una posible funcionalidad de DBP1 en diferentes compartimentos subcelulares. La sobreexpresión de 14-3-3 G provoca la exclusión de DBP1 del núcleo, modulando así su localización subcelular in vivo. Sin embargo, en el caso de la proteína truncada de DBP1 que sólo presenta el dominio C-terminal y que es por tanto incapaz de interaccionar con 14-3-3 G, se mantiene la distribución nucleocitoplasmática en presencia de la 14-3-3 G. Estos resultados indican que la modulación de la distribución núcleo-citoplasma de DBP1 está mediada por una interacción directa entre la 14-3-3 y su dominio N-terminal. Hasta el momento, podemos asegurar que una de las consecuencias de la interacción entre ambas proteínas es la exportación de DBP1 del núcleo, aunque no podemos descartar otros efectos de dicha interacción en la modulación de la función del factor transcripcional DBP1. A su vez, para descartar que la salida del núcleo de DBP1 sea una consecuencia de su liberación del ADN estudiamos la localización subcelular de la versión mutada de DBP1 incapaz de unirse al ADN. La acumulación de dicha versión mutada en el núcleo, indica que la exclusión nuclear de DBP1 implica una interacción directa con la 14-3-3 G, independientemente de su unión al ADN.

Todos los resultados obtenidos hasta el momento sugieren una posible participación de la 14-3-3 G en la regulación del gen CEVI1 mediada por DBP1. Estudios anteriores confirmaron que la represión del gen $C E V I 1$ es abolida en condiciones inductivas por una pérdida de unión de DBP1 al elemento 3a4 presente en el promotor de dicho gen (Carrasco et al, 2003). Si la 143-3 G participa en este escenario, una rápida inducción de 14-3-3 G promovería la salida de DBP1 del núcleo en estas condiciones gracias a la interacción entre ambas proteínas, provocando finalmente la consiguiente desrepresión de sus genes diana. Para verificar el modelo propuesto llevamos a cabo análisis de expresión por Northern-blot de los genes DBP1, CEVI1 y 14-3-3 G en respuesta al estímulo inductor, y a su vez se hizo un seguimiento de la localización subcelular de la fusión de DBP1 a GFP en ensayos de expresión transitoria en respuesta a este mismo estímulo. Los resultados obtenidos dan validez al modelo expuesto, ya que la expresión de 14-3-3 G se induce y precede en el tiempo a la de CEVI1 en condiciones que promueven la expresión de este gen. En estas mismas condiciones, DBP1 es progresivamente excluida del núcleo y su unión al elemento 3a4 en el promotor del gen CEVI1 se libera, provocando la desrepresión de la transcripción del gen. Por tanto, como modelo hipotético podríamos predecir que en condiciones basales, DBP1, mediante su unión al promotor de CEVI1, reprime su transcripción. Esta represión se liberará cuando, en condiciones inductivas, la interacción directa de 14-3-3 G con DBP1 provoque una exportación 
nuclear del complejo de ambas proteínas al citoplasma, impidiendo así la unión de DBP1 al promotor de CEVI1, y conduciendo finalmente a la inducción de dicho gen.

Todo el trabajo realizado nos ha permitido, no sólo la identificación de uno de los interactores del primer representante de esta nueva familia de factores de transcripción, sino también conocer el efecto de dicha interacción en la función reguladora de DBP1 así como establecer la implicación de dicho interactor en el mecanismo responsable de la regulación de la expresión génica mediada por DBP1.

Además de los mecanismos conocidos de regulación de los factores de transcripción, tales como la interacción con coactivadores u otros factores de transcripción, cabe la posibilidad de que la función de éstos puede modificarse a través de la regulación de su localización subcelular. Con este trabajo, las 14-3-3 se presentan como proteínas implicadas en dicha regulación, que en plantas apenas está documentada. Un ejemplo de ello es la regulación de la función del factor de transcripción RSG. Este factor de transcripción, que controla las concentraciones endógenas de giberelinas (GAs) en plantas, al unirse a una 14-3-3 es secuestrado en el citoplasma siendo incapaz de esta manera de regular sus genes diana en el núcleo (Igarashi et al., 2001). Así, las 14-3-3 modulan negativamente a RSG a través de la regulación de su localización intracelular. En nuestro caso, la interacción de la 14-3-3G con DBP1 y su participación en la regulación de genes diana del factor, aportan nuevos datos a la literatura que corroboran el que las proteínas 14-3-3 puedan funcionar como reguladores postraduccionales de factores de transcripción.

Con objeto de profundizar en la caracterización de los factores DBP como nuevos reguladores transcripcionales en plantas nos planteamos proseguir nuestro estudio en Arabidopsis thaliana, que por sus peculiares características se considera especie vegetal modelo por excelencia. En el genoma de Arabidopsis hemos identificado cuatro genes que codifican factores DBP, siendo AtDBP1 el miembro de la familia que mayor grado de similitud muestra con el factor DBP1 de tabaco. Por ello, nuestro primer objetivo se centró en un análisis funcional de AtDBP1, el cual, mediante ensayos in vitro con proteína recombinante purificada puso de manifiesto que la proteína de Arabidopsis AtDBP1 mantiene la capacidad de unión al ADN y la especifidad de DBP1, así como su actividad proteín-fosfatasa. Por tanto, la similitud estructural de AtDBP1 con DBP1 se refleja a nivel funcional.

A su vez, quisimos comprobar si esa similitud estructural entre proteínas de diferentes especies de plantas también permitía mantener la interacción con una proteína similar a la 14-3-3 G. El rastreo de una genoteca de Arabidopsis usando como cebo el factor AtDBP1 reveló que dicha proteína interacciona con la isoforma $\lambda$ de 14-3-3, también conocida como GRF6, que resultó ser un gen homólogo a la 14-3-3 G de tabaco y posiblemente el ortólogo funcional de Arabidopsis. La interacción entre ambas proteínas también está mediada por la región $\mathrm{N}$ terminal de AtDBP1, lo que refuerza el significado biológico de la interacción entre DBP1 de tabaco y $14-3-3 \mathrm{G}$. 
Las 14-3-3 exhiben un alto grado de conservación de secuencia entre especies (Wang \& Shakes, 1996), lo que puede implicar un alto grado de conservación funcional. Por ello, sería interesante verificar si en Arabidopsis se mantiene el mismo mecanismo de modulación de la localización subcelular, comprobando si dicha isoforma de 14-3-3 también es capaz de promover la salida del núcleo de AtDBP1 en las mismas condiciones en que sucede en tabaco.

Uno de los principales objetivos del proyecto ha sido conocer los procesos en cuya regulación están implicados los factores DBP y, en concreto, establecer su participación en los mecanismos de defensa de las plantas frente a estrés. Para ello, como aproximación experimental nos propusimos identificar genes diana de estos factores mediante el análisis comparativo del proteoma de plantas silvestres y de plantas mutantes que no expresan AtDBP1. De este modo, pretendíamos identificar dianas de AtDBP1 tanto a nivel de transcripción como sustratos de su actividad proteín-fosfatasa que podrían ser regulados a nivel post-traduccional. Para llevar a cabo dicho estudio se obtuvo de la colección del Instituto SALK (La Jolla, EE.UU.) una línea de inserción de ADN-T en el gen AtDBP1 que interrumpe su secuencia codificante aboliendo así su función. Se ha comprobado que los niveles de expresión de AtDBP1 de la línea homocigota para dicha inserción son insignificantes al comparar con las plantas silvestres. De entre los "spots" diferenciales observados entre ambos genotipos en el análisis proteómico se identificó un polipéptido que corresponde a una de las isoformas del factor de inicio de la traducción $4 \mathrm{E}$, conocido como elF(iso)4E, el cual presenta una baja acumulación en el mutante de inserción para AtDBP1, lo que indicaría que AtDBP1 contribuye positivamente a la acumulación de elF(iso)4E.

Con objeto de comprobar si el control que ejerce AtDBP1 sobre dicho factor es a nivel transcripcional o post-transcripcional se analizó la expresión de elF(iso)4E a nivel de ARNm mediante RT-PCR y a nivel de proteína mediante Western-blot, comprobando que existe una menor acumulación de la proteína eIF(iso)4E en la línea mutante atdbp1 al comparar con plantas Col-0, pero no así del ARNm. Por tanto, AtDBP1 debe afectar al nivel de acumulación de elF(iso)4E a nivel post-transcripcional. Posteriormente comprobamos la interacción específica entre ambas proteínas mediante ensayos de doble híbrido, lo que sugiere que la isoforma del factor de inicio de la traducción elF(iso)4E podría ser un sustrato susceptible a la desfosforilación mediada por AtDBP1. A su vez, la disponibilidad de un anticuerpo específico frente a elF(iso)4E ha permitido, mediante ensayos de coinmunoprecipitación, demostrar que ambas proteínas son capaces de interaccionar en la planta in vivo. Todo ello ha puesto de manifiesto que existe una interacción directa entre AtDBP1 y eIF(iso)4E.

El factor de inicio de la traducción eucariótico 4E y su isoforma exclusiva de plantas, elF(iso)4E, forman parte de los complejos $4 \mathrm{~F}$ e iso4F respectivamente (Browning, 1996). Estos complejos, formados por los factores 4A, 4G, 4E/iso4E y factores PABP (poly $(\underline{A})$ - $\underline{\text { binding }}$ protein), son requeridos junto a otros factores de iniciación para el inicio de la traducción de las proteínas, permitiendo la unión del ARNm al complejo de preiniciación. En concreto, los 
factores elF4E y elF(iso)4E tienen la función de reconocer y unirse a las estructuras CAP presentes en el extremo 5' de los ARNm (Preiss \& Hentze, 2003).

Durante mucho tiempo se ha reconocido la participación de genes de resistencia recesiva frente a virus en plantas, pero su naturaleza molecular se ha vinculado recientemente con componentes del complejo de inicio de la traducción eucariótico. Los factores de inicio de la traducción, y particularmente la familia proteica elF4E, se han mostrado como determinantes esenciales para la resistencia o susceptibilidad a infecciones de virus de ARN como los potyvirus. Está descrito que plantas con mutaciones en la secuencia codificante de elF(iso)4E que suprimen su función, presentan una pérdida de la susceptibilidad que exhiben las plantas silvestres del ecotipo Col-0 al ser infectadas por ciertos potyvirus (Lellis et al., 2002; Duprat et al, 2002). Estos mutantes muestran resistencia específica a potyvirus, por lo que a alguno de ellos se les conoce como mutantes Isp (loss-of-susceptibility to potyvirus). El análisis por Western-blot reveló que estos mutantes no presentan niveles detectables de elF(iso)4E, de lo que se deduce que la pérdida de la función de este factor confiere resistencia frente a potyvirus. Otros datos que demuestran la importante función de elF4E en la resistencia de las plantas frente a potyvirus se centran en los genes mo1 de lechuga para generar resistencia frente al Lettuce mosaic virus (LMV), el gen sbm1 de guisante para generar resistencia frente a Pea seed-borne mosaic virus (PSbMV) y el gen pot-1 de tomate frente al PVY y TEV (Nicaise et al, 2003; Gao et al, 2004; Ruffel et al, 2005). En todos estos casos, la resistencia se generó como consecuencia de cambios en aminoácidos en las proteínas 4E codificadas por los alelos de resistencia recesivos.

Además, se ha demostrado la interacción de proteínas VPg de varios potyvirus con elF4E o su isoforma eIF(iso)4E (Wittmann et al, 1997; Schaad et al, 2000; Léonard et al, 2000). El hecho de que la región de la VPg que interacciona con los factores de iniciación esté altamente conservada entre los potyvirus, y que una mutación en dicha región de la VPg que suprime la interacción impida la infección viral en la planta (Léonard et al, 2000), indican que la interacción VPg-4E juega un papel importante en el ciclo vital del virus, aunque su función precisa sigue siendo desconocida. En consecuencia, se ha sugerido que la VPg podría tener un papel en el inicio de la traducción comparable a la función de la estructura CAP del extremo 5' de los ARNs mensajeros eucarióticos; sirviendo como sitio de unión para el complejo de inicio de la traducción con el posterior reclutamiento de las subunidades ribosomales $40 \mathrm{~S}$ (Lellis et al., 2002). Sin embargo, se sabe que la región 5' no traducida del genoma viral participa en la iniciación a través de un sitio interno de entrada al ribosoma (IRES) (Carrington \& Freed, 1990; Levis \& Astier-Manifacier, 1993); por tanto no parecería crucial el complejo de unión al CAP para el reclutamiento del ARN viral. Otra posibilidad que se baraja es que la interacción VPgeIF4E juegue un papel en la replicación del genoma, permitiendo una mayor estabilidad del ARN viral y facilitando el inicio de la replicación del ARN. El hecho de que elF4E se encuentre próximo a los factores PABP gracias al factor puente $4 \mathrm{G}$, permitiría que la VPg uridilada, que sirve como cebador para la síntesis de la cadena complementaria, se localizara próxima a la región poliA, facilitándose así el inicio de la replicación del ARN (Herold \& Andino, 2001). Una 
tercera hipótesis plantea una posible función de esta interacción en el movimiento célula a célula, debido a la interacción descrita entre estructuras del citoesqueleto con la maquinaria traduccional (Bokros et al., 1995; Gao et al., 2004).

Por tanto, existen muchas evidencias de la importancia de los factores elF4E y elF(iso)4E en el ciclo vital de los potyvirus. Se consideran factores del hospedador esenciales para una exitosa progresión de la infección vírica, participando así en la resistencia recesiva frente a potyvirus en muchas especies de plantas (Robaglia \& Caranta, 2006).

Los datos obtenidos con el análisis proteómico son de gran interés, pues establecen una relación directa entre AtDBP1 y la respuesta defensiva a virus a través de elF(iso)4E, y por tanto pueden contribuir al entendimiento de los procesos biológicos en los que está implicada la función de AtDBP1. Además, este resultado afianza el contexto original en el que se identificó esta nueva familia de factores transcripcionales, ya que el factor DBP1 de tabaco fue aislado a partir del promotor del gen CEVI1, el cual se induce en interacciones víricas compatibles. Así, retomar el mismo escenario donde actúa el factor DBP1, podría indicar una conservación entre especies del contexto biológico donde actúan estos factores.

Por consiguiente, la menor acumulación de elF(iso)4E en plantas mutantes atdbp1 sugiere la posibilidad de que la pérdida de función de AtDBP1 pueda desencadenar una resistencia a potyvirus, al menos parcialmente. Por esta razón, se inocularon plantas Col-0 y mutantes atdbp1 con un clon infeccioso del potyvirus PPV o virus de la sharka, portador del gen marcador GFP. El análisis por qRT-PCR y por Western Blot reveló una menor acumulación viral en tejido sistémico no inoculado en plantas mutantes atdbp1 frente a plantas Col-0. A su vez, gracias al gen marcador GFP, realizamos un seguimiento del movimiento y distribución del virus mediante microscopia de fluorescencia que puso de manifiesto un marcado retraso de la acumulación y el movimiento viral en las plantas mutantes respecto a plantas Col-0. Esta menor invasión viral en tejidos distales de la planta podría interpretarse como una resistencia parcial frente a estos virus en nuestro mutante. Por tanto, podemos concluir que la pérdida de función de $A t D B P 1$ ralentiza y atenúa la infección vírica, pero hasta el momento no podemos establecer en qué punto están afectadas las diferentes etapas de la infección, como la traducción y replicación del genoma viral y/o el movimiento de las partículas víricas a corta y larga distancia.

Debido a la ausencia de síntomas en las infecciones con PPV, analizamos la respuesta de plantas mutantes atdbp1 frente a otro miembro de la familia de los potyvirus causante de síntomas en Arabidopsis, el TuMV. Ello, a su vez, nos permitiría comprobar si la pérdida de susceptibilidad observada para el PPV puede extenderse a otros miembros del género Potyvirus. La inoculación con TuMV ha provocado una sintomatología mucho menos severa en plantas mutantes atdbp1 que la mostrada por plantas control Col-0. Por tanto, la pérdida de la función de AtDBP1 parece desencadenar una resistencia al menos parcial a varios miembros de la familia de los potyvirus. En este caso, era previsible que la menor acumulación de la proteína eIF(iso)4E en el mutante atdbp1 también influyera en el curso de la 
infección vírica con el TuMV, ya que está descrita la interacción entre la VPg del TuMV y elF(iso)4E (Wittmann et al., 1997). Así, nuestro resultado confirma que el TuMV precisa de la isoforma en cuestión para su avance por la planta y desencadenar así una infección exitosa. Varios estudios han demostrado que los potyvirus difieren en su capacidad para usar diferentes isoformas del factor eIF4E de una planta hospedadora. Así, mutaciones "knockout" en el gen elF(iso)4E de Arabidopsis thaliana previenen las infecciones del TUMV, LMV, TEV y PPV (Lellis et al, 2002; Duprat et al, 2002; Decroocq et al, 2006), no siendo capaz de frenar la infección por el Clover yellow vein virus (CIYVV). Contrariamente, mutaciones que suprimen elF4E permiten la replicación del TuMV pero no la del CIYVV (Sato et al, 2005). Por tanto, mutaciones en un determinado miembro de la familia génica $4 \mathrm{E}$ parecen suficientes para asegurar resistencia frente a varios potyvirus, mientras que otros miembros de la familia $4 \mathrm{E}$ no son capaces de sostener la replicación viral. Esto sugiere que, generalmente, las isoformas elF4E y elF(iso)4E no presentan funciones solapantes en las interacciones planta-virus, no existiendo por tanto redundancia funcional. A pesar de que muchos potyvirus precisan específicamente una de las isoformas para su ciclo vital, hay descrito algún caso en el que el virus puede usar una u otra isoforma. Un ejemplo de ello lo podemos encontrar en pimiento, donde la resistencia al PVY y TEV depende de la mutación de un único gen eIF4E (locus pvr2), mientras que la resistencia al Pepper veinal mottle virus (PVMV) requiere tanto del locus pvr2 como de pvr6, correspondiente a un gen que codifica elF(iso)4E (Ruffel et al, 2006). Aunque generalmente las funciones de ambas isoformas de elF4E no son intercambiables, el hecho de que elF4E y elF(iso)4E sean reclutados para la replicación viral hace sospechar que exista una característica conservada entre las isoformas implicada en este proceso. Sabiendo esto, sería interesante estudiar en nuestro mutante atdbp1 el fenotipo frente a los otros potyvirus descritos hasta el momento que precisen de la isoforma elF(iso)4E, y así poder confirmar que la falta de AtDBP1 presenta un efecto negativo en la propagación vírica de los miembros de los potyvirus que precisan dicha isoforma del factor. Las inoculaciones con potyvirus que exclusivamente precisen elF4E para completar su ciclo vital en la planta podrían confirmar la especificidad del efecto de AtDBP1 o por el contrario indicarnos que este efecto se puede extender de forma general al género Potyvirus. El nivel de acumulación de la proteína elF4E en nuestro mutante atdbp1, así como su posible interacción con AtDBP1, podría sernos útil para saber si AtDBP1 podría ejercer un control sobre dicha isoforma, traduciéndose en una pérdida de susceptibilidad parcial a la infección por potyvirus, que en este caso, correspondería a aquellos miembros que precisaran la proteína elF4E para su ciclo vital. De ello se derivaría importante información acerca de la participación de factores DBP como AtDBP1 en los mecanismos moleculares que implican a ambas isoformas en la infección por potyvirus.

Con los datos recopilados hasta el momento proponemos una posible explicación para el mecanismo molecular que subyace a la resistencia parcial de las plantas que presentan ausencia de la función de AtDBP1. Según nuestro modelo, la infección de una planta Col-0 con un potyvirus podría potenciar la función de AtDBP1 en el citoplasma, permitiendo así que AtDBP1 pueda unirse a elF(iso)4E con la finalidad de desfosforilar a dicho factor. De esta 
manera, el balance entre forma fosforilada y desfosforilada se decantaría hacia la forma desfosforilada, contribuyendo posiblemente a una mayor estabilidad del factor eIF(iso)4E. En este punto, por tanto, existiría una mayor disponibilidad del factor elF(iso)4E, que favorecería la unión con la proteína VPg del virus, permitiendo y/o incrementando así la tasa de traducción/replicación viral y/o movimiento viral. Esto explicaría el fenotipo de susceptibilidad que presentan estas plantas ante la infección vírica.

Por el contrario, en las plantas mutantes atdbp1, al estar suprimida la función de AtDBP1, el virus sería incapaz de favorecer el papel de la fosfatasa en el citoplasma. La falta de AtDBP1 se traduciría en una mayor acumulación de la forma fosforilada de elF(iso)4E, que presumimos podría ser más susceptible a la degradación vía proteosoma. Evidentemente, ello conduciría a una menor disponibilidad del factor elF(iso)4E, que se manifestaría como un retraso en la tasa de traducción/replicación viral y/o movimiento viral, desencadenando así la pérdida parcial de susceptibilidad observada en las plantas mutantes para AtDBP1. Con este modelo se justificaría la baja acumulación del factor elF(iso)4E en nuestro mutante así como el mecanismo molecular que regula su actividad.

En cuanto a las primeras etapas del modelo, varios supuestos podrían explicar cómo la infección vírica puede promover la función de AtDBP1 en el citoplasma. Así, la percepción del patógeno vírico puede incrementar el nivel de expresión de AtDBP1 y/o provocar una relocalización subcelular de la proteína que favorezca su salida del núcleo. Alternativamente, el potenciamiento de la actividad catalítica de AtDBP1 mediante la modulación de activadores e inhibidores de fosfatasas también podría promover su función. Análisis de la expresión de AtDBP1 por RT-PCR cuantitativa en tejido sistémico tras la inoculación con PPV, han descartado un aumento del nivel de expresión tras la percepción del virus en plantas Col-0. Por otra parte, para comprobar si el factor regulador AtDBP1 se relocaliza en el citoplasma tras la infección vírica, nos planteamos aproximaciones experimentales de expresión transitoria en $N$. benthamiana, que estamos llevando a cabo en la actualidad.

Siguiendo con nuestra hipótesis de partida, la infección vírica podría promover una mayor estabilización del factor elF(iso)4E que sería el desencadenante del fenotipo de susceptibilidad que presentan las plantas Col-0. El análisis de la acumulación de elF(iso)4E por Western blot tras la infección sustenta esta premisa, ya que se observa un incremento en la acumulación del factor de inicio de la traducción tanto en hojas inoculadas como en el tejido sistémico de plantas Col-0 infectadas con el PPV. Este aumento de la acumulación de elF(iso)4E tras la infección es más evidente en el tejido sistémico, donde el virus invade prácticamente toda la superficie foliar, que en el tejido local, donde se limita al sistema vascular central. De esta manera, podemos afirmar que la infección vírica desencadena una mayor estabilización del factor elF(iso)4E permitiendo así que el virus pueda replicarse y/o traducirse de forma eficiente con el objetivo final de infectar la planta sistémicamente. 
Con objeto de atribuir a la actividad fosfatasa de AtDBP1 la función de promover una mayor estabilización del factor elF(iso)4E, quisimos comprobar si cuando se elimina la función de AtDBP1, la menor acumulación de dicho factor se debe a una mayor tasa de degradación vía proteosoma. Tras la aplicación del inhibidor del proteosoma MG-132 se puede observar un aumento en la acumulación de eIF(iso)4E en plantas mutantes atdbp1, no apreciándose diferencias en las plantas silvestres. Estos resultados parecen respaldar nuestra hipótesis de partida, ya que la ausencia de AtDBP1 desencadenaría una mayor representación de la forma fosforilada de elF(iso)4E en la planta. Una mayor acumulación de la misma en nuestro mutante, tras inhibir el proteosoma, apunta a que esta isoforma es susceptible de ser degradada por dicha vía. Por el contrario, no podemos observar ese aumento de acumulación del factor elF(iso)4E en las plantas Col-0, ya que la función de AtDBP1 impide la desviación del balance hacia la forma fosforilada, presentándose como mayoritaria la desfosforilada. En este caso, el hecho de que la inhibición del proteosoma no afecte a la acumulación de elF(iso)4E refuerza el supuesto de que la desfosforilación mediada por AtDBP1 contribuye a una mayor estabilización del factor de inicio de la traducción.

Los resultados obtenidos en este trabajo demuestran la existencia en plantas de un mecanismo de regulación para el factor elF(iso)4E vía proteosoma mediado por fosforilación. Estos datos son de gran relevancia debido al poco conocimiento existente sobre el mecanismo de regulación de estos factores en el reino vegetal. Por el contrario, en animales se ha demostrado que la fosforilación es un proceso esencial en la regulación de la función de elF4E. Existen varios estímulos extracelulares como hormonas, factores de crecimiento y mitógenos estimulantes del crecimiento celular que incrementan el estado de fosforilación de elF4E, correlacionándose con un aumento de la síntesis de proteínas (Gingras et al., 1999). El inicio de la traducción podría estar regulado por la abundancia de la forma fosforilada de elF4E, ya que parece ser la forma más activa. Además, el estado de fosforilación de estos factores afecta a su afinidad por la estructura CAP de los ARNm, aunque no está muy claro el efecto que ello provoca en dicha unión. Algunos trabajos aseguran que la forma fosforilada de elF4E tiene mayor afinidad por la estructura CAP que la no fosforilada (Minich et al., 1994). Pero otros aseguran que la fosforilación de elF4E disminuye su afinidad por la estructura CAP, aumentando de igual manera la síntesis de proteínas (Scheper et al, 2002; Zuberek et al., 2003). En trabajos con germen de trigo también se ha confirmado que la reducción de la unión al CAP está asociada con la fosforilación de elF(iso)4E, lo que se propuso como mecanismo general de regulación en todos los eucariotas (Khan \& Goss, 2004).

Por otra parte, la fosforilación, además de modular la función de elF4E, también tiene un efecto indirecto sobre la actividad de estos factores a través de unas proteínas represoras conocidas como 4E-BPs (elF4E-binding proteins). Las proteínas 4E-BPs tienen la capacidad de unirse a los factores elF4E para inactivarlos, dependiendo de su estado de fosforilación. En este caso, la fosforilación de determinados residuos en estas proteínas represoras impide la unión con los factores elF4E (Marcotrigiano et al., 1999; Pause et al., 1994; Lin et al., 1994; 
Fadden et al., 1997; Gingras et al., 1998). La unión de 4E-BPs con elF4E no parece afectar la unión de elF4E a la estructura CAP de los ARN mensajeros (Pause et al., 1994), pero sí a su asociación con elF4G, suprimiendo la formación y ensamblaje del complejo elF4F (Haghighat et al., 1995). Las proteínas 4E-BPs y elF4G compiten por la unión a elF4E al poseer el motivo necesario para que se establezca dicha interacción (Mader et al., 1995). Por tanto, las 4E-BPs actúan como inhibidores competitivos para prevenir la formación del complejo elF4F. Sin embargo, este mecanismo de regulación post-traduccional no existe en plantas, no habiéndose encontrado los ortólogos de estas proteínas en el reino vegetal.

Los factores de iniciación de plantas también sufren cambios en el estado de fosforilación; existen trabajos que demuestran que estos cambios pueden venir dados como resultado de situaciones de estrés, de una infección viral y de otros cambios ambientales (Gallie et al., 1997). Por tanto, en el reino vegetal, la fosforilación también se presenta como una importante modificación que debe intervenir en la traducción de ARNm a través de su interferencia con la actividad de unión al CAP. Aún así, poco se conoce sobre las consecuencias funcionales de esta modificación y, aunque se han descrito varios mecanismos para la regulación de estos factores en mamíferos, este es un aspecto todavía desconocido en el reino vegetal. Con el presente trabajo, AtDBP1 se presenta como un elemento esencial de un posible mecanismo para la regulación de la actividad de elF(iso)4E en plantas. De esta manera, la actividad fosfatasa de nuestro factor AtDBP1 sería capaz de modular la degradación de este factor y regular así su función en las células vegetales.

Debido al papel que desempeñan estos factores de inicio de la traducción en las infecciones virales, ya que se presentan como factores de la planta necesarios para que los virus completen su ciclo vital, nuestros resultados nos llevarían al descubrimiento de un nuevo escenario para la función de AtDBP1, que podría extenderse a los otros miembros de la familia DBP en Arabidopsis thaliana. Además la asignación de un significado biológico a la actividad fosfatasa de AtDBP1 presentaría a dicha proteína como un nuevo factor, inherente al hospedador, implicado en la compleja interacción que se genera entre la planta hospedadora y el virus durante la infección. Por todo esto, creemos que la manipulación de la función de AtDBP1 es una buena herramienta para hacer frente a infecciones virales, ya que la ausencia de AtDBP1 contribuye a disminuir los niveles del factor elF(iso)4E, traduciéndose en un fenotipo de resistencia frente a miembros del genero Potyvirus, el cual es responsable de pérdidas significativas en cultivos ornamentales, agrícolas y hortícolas (Revers et al., 1999). 

CONCLUSIONES 



\section{CONCLUSIONES}

1. El factor de transcripción DBP1 de tabaco, primer representante de una nueva familia de reguladores de plantas, presenta capacidad de unión a ADN específica de secuencia en su dominio $\mathrm{N}$-terminal. Este rasgo característico requiere de un motivo, altamente conservado entre factores DBP de especies de plantas mono y dicotiledóneas, conocido como motivo DNC ( $\underline{D} B P \underline{N}$-terminal $\underline{c o r e})$.

2. La isoforma $G$ de una proteína 14-3-3 es el primer factor proteico identificado que interacciona con DBP1. La interacción con dicha proteína se establece a través del dominio N-terminal de DBP1, en concreto a una región adyacente al motivo DNC sin comprometer al mismo. La 14-3-3 G es capaz de alterar la localización subcelular de DBP1, provocando su exclusión nuclear y por tanto modulando su distribución entre núcleo y citoplasma. A su vez, la proteína 14-3-3 G participa en la regulación de la expresión del gen CEVI1 mediado por DBP1. Bajo condiciones que promueven la expresión de CEVI1, la rápida inducción de 14-3-3 G precede en el tiempo a la de CEVI1, desencadenando una progresiva exportación nuclear de DBP1 que permite así la liberación de la represión del gen mediada por DBP1.

3. En el genoma de Arabidopsis se han identificado cuatro genes que codifican factores DBP, siendo AtDBP1 el miembro de la familia que mayor grado de similitud muestra con el factor DBP1 de tabaco. La proteína de Arabidopsis AtDBP1 además de presentar actividad proteín-fosfatasa, mantiene la capacidad de unión a ADN al igual que el factor regulador de tabaco DBP1, demostrándose así que la similitud estructural se refleja a nivel funcional. A su vez, el factor regulador AtDBP1 interacciona con la isoforma $\lambda$ de 14-3-3 que resulta ser homóloga a la 14-3-3 G de tabaco, estando también mediada la interacción a través de su región $\mathrm{N}$-terminal.

4. El mutante de inserción de T-DNA atdbp1 presenta una baja acumulación del factor elF(iso)4E, una de las isoformas del factor de inicio de la traducción 4E. La relación entre AtDBP1 y eIF(iso)4E se establece a nivel post-transcripcional donde, a través de una interacción directa entre ambas proteínas, la actividad proteín-fosfatasa de AtDBP1 contribuye a una mayor estabilización del factor de inicio de la traducción. De esta manera, la pérdida de función de AtDBP1 al traducirse en una menor acumulación del factor elF(iso)4E, conlleva a un fenotipo de resistencia parcial a potyvirus manifestándose como un retraso de la acumulación y movimiento viral en la planta. 

BIBLIOGRAFÍA 



\section{BIBLIOGRAFIA}

Abel, P. P., Nelson, R. S., De, B., Hoffman, N., Rogers, S. G., Fraley, R. T. \& Beachy, R. N. (1986). Delay of disease development in transgenic plants that express the Tobacco mosaicvirus coat protein gene. Science 236, 738-743.

Ade, J., DeYoung, B. J., Golstein, C. \& Innes, R. W. (2007). Indirect activation of a plant nucleotide binding site-leucine-rich repeat protein by a bacterial protease. Proc. Natl. Acad. Sci. USA 104, 2531-2536.

Agrios, G.N. (2005). Plant Pathology. Academic Press, London.

Ahlquist, P., Noueiry, A. O., Lee, W. M., Kushner, D. B. \& Dye, B. T. (2003). Host factors in positive-strand RNA virus genome replication. J. Virol. 77, 8181- 8186.

Aitken, A. (1996). 14-3-3 and its possible role in co-ordinating multiple signaling pathways. Trends Cell Biol. 6, 341-347.

Aitken, A., Baxter, H., Dubois, T., Clokie, S., Mackie, S., Mitchell, K., Peden, A. \& Zemlickova, E. (2002). Specificity of 14-3-3 isoform dimer interactions and phosphorylation. Biochem. Soc. Trans. 30, 351-360.

Alamillo, J. M., Saenz, P. \& García, J. A. (2006). Salicylic acid-mediated and RNA-silencing defense mechanisms cooperate in the restriction of systemic spread of plum pox virus in tobacco. Plant J. 48, 217-227.

Anandalakshmi, R., Pruss, G. J., Ge, X., Marathe, R., Mallory, A. C., Smith, T. H. \& Vance, V. B. (1998). A viral suppressor of gene silencing in plants. Proc. Natl. Acad. Sci. USA 95, 1307913084.

Audy, P., Palukaitis, P., Slack, S. A. \& Zaitlin, M. (1994). Replicase-mediated resistance to Potato virus $Y$ in transgenic tobacco plants. Mol. Plant Microb. Interact. 7, 15-22.

Axtell, M. J. \& Staskawicz, B. J. (2003). Initiation of RPS2-specified disease resistance in Arabidopsis is coupled to the AvrRpt2-directed elimination of RIN4. Cell 112, 369-377.

Baldi, P., Patocchi, A., Zini, E., Toller, C., Velasco, R. \& Komjanc, M. (2004). Cloning and linkage mapping of resistance gene homologues in apple. Theor. Appl. Genet. 109, 231-239. 
Baulcombe, D. (2004). RNA silencing in plants. Nature 431, 356-363.

Baulcombe, D. (2005). RNA silencing. Trends Biochem. Sci. 30, 290-293.

Bent, A. F. \& Mackey, D. (2007). Elicitors, Effectors, and $R$ Genes: The New Paradigm and a Lifetime Supply of Questions. Annu. Rev. Phytopathol. 45, 399-436.

Bi, Y. M., Kenton, P., Mur, L., Darby, R., and Draper, J. (1995). Hydrogen peroxide does not function downstream of salicylic acid in the induction of PR protein expression. Plant J. 8, 235245.

Bienz, K., Egger, D., Troxler, M. \& Pfister, T. (1992). Structural and functional characterization of the poliovirus replication complex. J. Virol. 66, 2740-2747.

Bokros, C. L., Hugdahl, J. D., Kim, H. H., Hanesworth, V. R., Vanheerden, A., Browning, K. S. \& Morejohn, L. C. (1995). Function of the p86 subunit of eukaryotic initiation factor (iso) $4 \mathrm{~F}$ as a microtubule-associated protein in plant cells. Proc. Natl. Acad. Sci. USA 92, 7120-7124.

Borman, A. M., Michel, Y. M. \& Kean, K. M. (2000). Biochemical characterisation of cap-poly(A) synergy in rabbit reticulocyte lysates: the elF4G-PABP interaction increases the functional affinity of elF4E for the capped mRNA 5'-end. Nucl. Acids Res. 28, 4068-4075.

Brederode, F. T., Linthorst, H. J. \& Bol, J. F. (1991). Differential induction of acquired resistance and PR gene expression in tobacco by virus infection, ethephon treatment, UV light and wounding. Plant Mol. Biol. 17, 1117-25.

Brigneti, G., Voinnet, O., Li, W.-X., Ji, L.-H., Ding, S.-W., \& Baulcombe, D. C. (1998). Viral pathogenicity determinants are suppressers of transgene silencing in Nicotiana benthamiana. EMBO J. 17, 6739- 6746.

Brommonschenkel, S. H. \& Tanksley, S. D. (1997). Map-based cloning of the tomato genomic region that spans the Sw-5 tospovirus resistance gene in tomato. Mol. Gen. Genet. 256, 121126.

Browning, K.S. (1996). The plant translational apparatus. Plant Mol. Biol. 32, 107-144.

Buck, K. W. (1999). Replication of Tobacco mosaic virus RNA. Philos. Trans. R. Soc. Lond. B, Biol. Sci. 354, 613-627. 
Bunney, T. D., van den Wijngaard, P. W. J. \& de Boer, A. H. (2002). 14-3-3 protein regulation of proton pumps and ion channels. Plant Mol. Biol. 50, 1041-1051.

Campbell, M. A., Fitzgerald, H. A. \& Ronald, P. C. (2002). Engineering pathogen resistance in crop plants. Transgenic Res. 11, 599-613.

Carrasco, J. L., Ancillo, G., Mayda, E., \& Vera, P. (2003). A novel transcription factor involved in plant defense endowed with protein phosphatase activity. EMBO J.22, 3376-3384.

Carrington, J. C., Cary, S. M., Parks, T. D. \& Dougherty, W. G. (1989). A second proteinase encoded by a plant potyvirus genome. EMBO J. 8, 365-370.

Carrington, J. C. \& Dougherty, W. G. (1987). Small nuclear inclusion protein encoded by a plant potyvirus genome is a protease. J. Virol. 61, 2540-2548.

Carrington, J. C. \& Freed, D. D. (1990). Cap-independent enhancement of translation by a plant potyvirus 50 non-translated region. J. Virol. 64, 1590-1597.

Carrington, J. C., Kasschau, K. D., Mahajan, S. K., \& Schaad, M. C. (1996). Cell-to-cell and long-distance transport of viruses in plants. Plant Cell 8, 1669-1681.

Chandra, S. \& Low, P. S. (1995). Role of phosphorylation in elicitation of the oxidative burst in cultured soybean cells. Proc. Natl. Acad. Sci. USA 92, 4120-4123.

Chen, M. H., Tian, G. W., Gafni, Y. \& Citovsky, V. (2005). Effects of calreticulin on viral cell-tocell movement. Plant Physiol. 138, 1866-1876.

Chisholm, S. T., Mahajan, S. M., Whitham, S. A., Yamamoto, M. L. \& Carrington, J. C. (2000). Cloning of the Arabidopsis RTM1 gene, which controls restriction of long-distance movement of Tobacco etch virus. Proc. Natl. Acad. Sci. USA 97, 489-494.

Chisholm, S. T., Coaker, G., Day, B. \& Staskawicz, B. J. (2006). Host-microbe interactions: shaping the evolution of the plant immune response. Cell 124, 803-814.

Chisholm, S. T., Parra, M. A., Anderberg, R. J. \& Carrington, J. C. (2001). Arabidopsis RTM1 and RTM2 genes function in phloem to restrict long-distance movement of Tobacco etch virus. Plant Physiol. 127, 1667-1675.

Chung, B., Miller, W. A., Atkins, J. F. \& Firth, A. E. (2008). An overlapping essential gene in the Potyviridae. Proc. Natl. Acad. Sci. USA 105, 5897-5902. 
Clark, D., Durner, J., Navarre, D. A., Klessig, D. F. (2000). Nitric oxide inhibition of tobacco catalase and ascorbate peroxidase. Mol. Plant Microb. Interact. 13, 1380-1384.

Clark, S. E., Williams, R. W., \& Meyerowitz, E. M. (1997). The CLAVATA1 gene encodes a putative receptor kinase that controls shoot and floral meristem size in Arabidopsis. Cell 89, $575-585$

Collinge, D., B., Lund, O. S. \& Thordal-Christensen, H. (2008). What are the prospects for genetically engineered, disease resistant plants? Eur. J. Plant Pathol. 121, 217-231.

Comparot, S., Lingiah, G. \& Martin, T. (2003). Function and specificity of 14-3-3 proteins in the regulation of carbohydrate and nitrogen metabolism. J. Exp. Bot. 54, 595-604.

Dalmay, T., Hamilton, A., Rudd, S., Angell, S. \& Baulcombe, D. C. (2000). An RNA-dependent RNA polymerase gene in Arabidopsis is required for post-transcriptional gene silencing mediated by a transgene but not by a virus. Cell 101, 543-553.

Das, A. K., Helps, N. R., Cohen, P. T. W. \& Barford, D. (1996). Crystal structure of the.protein serine/threonine phosphatase $2 \mathrm{C}$ at 2.0 A resolution. EMBO J. 15, 6798-6809.

Dasgupta, I., Malathi, V. G. \& Mukherjee, S. K. (2003). Genetic engineering for virus resistance. Curr. Sci. 84, 341-354.

Day, B., Dahlbeck, D., Huang, J., Chisholm, S. T., Li, D. \& Staskawicz, B. J. (2005). Molecular basis for the RIN4 negative regulation of RPS2 disease resistance. Plant Cell 17, 1292-1305.

de Torres-Zabala, M., Truman, W., Bennett, M. H., Lafforgue, G., Mansfield, J. W., Rodríguez Egea, P., Bogre, L. \& Grant, M. (2007). Pseudomonas syringae pv. tomato hijacks the Arabidopsis abscisic acidsignalling pathway to cause disease. EMBO J. 26, 1434-1443.

Decroocq, V., Sicard, O., Alamillo, J. M., Lansac, M., Eyquard, J.P., García, J. A. Candresse, T., Le Gall, O. \& Revers, F. (2006). Multiple resistance traits control Plum pox virus infection in Arabidopsis thaliana. Mol. Plant Microb. Interact. 19, 541-549.

Delaney, T.P. (2000). New mutants provide clues into regulation of systemic acquired resistance. Trends Plant Sci. 5, 49-51.

Delaney, T P., Uknes, S., Vernooij, B., Friedrich, L., Weymann, K., Negrotto, D., Gaffney, T., Gut-Rella, M., Kessmann, H., Ward, E. \& Ryals, J. (1994). A central role of salicylic acid in plant disease resistance. Science 266, 1247-1250. 
Deleris, A., Gallego-Bartolome, J., Bao, J., Kasschau, K. D., Carrington, J. D. \& Voinnet, O. (2006). Hierarchical action and inhibition of plant dicer-like proteins in antiviral defense. Science $313,68-71$.

Deng, Z., Huang, S., Ling, P., Chen, C., Yu, C., Weber, C. A., Moore, G. A. \& Gmitter, F. G. (2000). Cloning and characterization of NBS-LRR class resistance-gene candidate sequences in citrus. Theor. Appl. Genet. 101, 814-822.

Di Gaspero, G. \& Cipriani, G. (2002). Resistance gene analogs are candidate markers for disease-resistance genes in grape (Vitis spp.). Theor. Appl. Genet. 106, 163-172.

Díaz-Pendón, J. A., Truniger, V., Nieto, C., García-Mas, J., Bendahmane, A. \& Aranda, M. (2004). Advances in understanding recessive resistance to plant viruses. Mol. Plant Pathol. 5, 223-233.

Dineshkumar, S. P., Whitham, S., Choi, D., Hehl, R., Corr, C. \& Baker, B. (1995). Transposon tagging of Tobacco mosaic virus resistance gene $\mathrm{N}$ : its possible role in the TMV-N-mediated signal transduction pathway. Proc. Natl. Acad. Sci. USA 92, 4175-4180.

Doke, N., Miura, Y., Sanchez, L. M., Park, H. J., Noritake, T., Yoshioka, H. \& Kawakita, K. (1996). The oxidative burts protects plants against pathogen attack: mechanism and role as an emergency signal for plant biodefense - a review. Gene 179, 45-51.

Dolja, V. V., Haldeman-Cahill, R., Montgomery, A. E., Vandenbosch, K. A. \& Carrington, J. C. (1995). Capsid protein determinants involved in cell-to-cell and long-distance movement of tobacco etch potyvirus. Virology. 206, 1007-1016.

Dolja, V.V., Haldeman R., Robertson, N.L., Dougherty, W.G \& Carrington, J.C. (1994). Distinct functions of capsid protein in assemly and movement of Tobacco etch potyvirus in plants. $E M B O$ J. 13, 1482-1491.

Dondini, L., Costa, F., Tataranni, G., Tartarini, S. \& Sansavini, S. (2004). Cloning of apricot RGAs (Resistance Gene Analogs) and development of molecular markers associated with sharka (PPV) resistance. J. Horticul. Science and Biotech. 79, 729-734.

Dong, X. (1998). SA, JA, ethylene, and disease resistance in plants. Curr. Opin. Plant. Biol. 1, 316-323. 
Duprat, A., Caranta, C., Revers, F., Menand, B., Browning, K. S. \& Robaglia, C. (2002). The Arabidopsis eukaryotic initiation factor (iso) $4 \mathrm{E}$ is dispensable for plant growth but required for susceptibility to potyviruses. Plant J. 32, 927-934.

Durrant, W. E. \& Dong, X. (2004). Systemic acquired resistance. Annu. Rev. Phytopathol. 42, 185-209.

Eckardt, N. A. (2001).Transcription factors dial 14-3-3 for nuclear shuttle. Plant Cell 13, 2385 2389.

Ellis, J., Dodds, P. \& Pryor, T. (2000). Structure, function and evolution of plant disease resistance genes. Curr. Opin. Plant. Biol. 3, 278-284.

Fadden, P., Haystead, T. A. \& Lawrence, J. C. (1997). Identification of phosphorylation sites in the translational regulator, PHAS-I, that are controlled by insulin and rapamycin in rat adipocytes. J. Biol. Chem. 272, 10240-10247.

Fauquet, M. C. \& Mayo, M. A. (1999). Abbreviations for plant virus names - 1999. Arch. Virol. 144, $1249-1273$.

Feys, B. J. \& Parker, J. E. (2000). Interplay of signaling pathways in plant disease resistance. Trends Genet. 16, 449-55.

Fraser, R. S. S. (1990). The genetics of resistance to plant viruses. Annu. Rev. Phytopathol. 28, 179-200.

Fraser, R. S. S. (1999). Plant resistance to viruses. En: Encyclopedia of Virology (A. Granoff \& R. G. Webster, eds), pp. 1300-1307. Academic Press, San Diego.

Frischmuth, T. \& Stanley, J. (1993). Strategies for the control of geminivirus diseases. J. Sem. Virol. 4, 329-337.

Fu, H., Subramanian, R. R. \& Masters, S. C. (2000). 14-3-3 proteins: structure, function and regulation. Annu. Rev. Pharmacol. Toxicol. 40,17-47.

Gaffney, T., Friedrich, L., Vernooij, B., Negrotto, D., Nye, G., Uknes, S., Ward, E., Kessmann, H. \& Ryals, J. (1993). Requirement of salicylic-acid for the induction of systemic acquiredresistance. Science 261, 754-756. 
Gallie, D. R., Le, H., Caldwell, C., Tanguay, R. L., Hoang, N. X., \& Browning, K. S. (1997). The phosphorylation state of translation initiation factors is regulated developmentally and following heat shock in wheat. J. Biol. Chem. 272, 1046-1053.

Gao, Z., Johansen, E., Eyers, S., Thomas, C. L., Ellis, T. H. N. \& Maule, A. J. (2004). The potyvirus recessive resistance gene, sbm1, identifies a novel role for translation initiation factor elF4E in cell-to-cell trafficking. Plant J. 40, 376-385.

Garcia, J. A., Riechmann, J. L. \& Lain, S. (1989). Proteolytic activity of the Plum pox potyvirus Nla-like protein in Escherichia coli. Virology 170, 362-369.

Ghabrial, S. A., Smith, H. A., Parks, T. D. \& Dougherty, W. G. (1990). Molecular genetic analyses of the Soybean mosaic virus Nla protease. J. Gen. Virol. 71, 1921-1927.

Gillespie, T., Boevink, P., Haupt, S., Roberts, A. G., Toth, R., Valentine, T., Chapman, S. \& Oparka, K. J. (2002). Movement protein reveals that microtubules are dispensable for the cellto-cell movement of Tobacco mosaic virus. Plant Cell 14, 1207-1222.

Gingras, A.-C., Kennedy, S. G., O'Leary, M. A., Sonenberg, N. and Hay, N. (1998). 4E-BP1, a repressor of mRNA translation, is phosphorylated and inactivated by the Akt(PKB) signaling pathway. Genes Dev. 12, 502-513.

Gingras, A., Raught, B. \& Sonenberg, N. (1999). elF4 initiation factors: effectors of mRNA recruitment to ribosomes and regulators of translation. Annu. Rev. Biochem. 68, 913-963.

Glazebrook, J. (1999). Genes controlling expression of defense responses in Arabidopsis. Curr. Opin. Plant Biol. 2, 280-286.

Glazebrook, J. (2001). Genes controlling expression of defense responses in Arabidopsis--2001 status. Curr. Opin. Plant Biol. 4, 301-308.

Golemboski, D. B., Lomonossoff, G. P. \& Zaitlin, M. (1990). Plants transformed with a Tobacco mosaic virus nonstructural gene sequence are resistant to the virus. Proc. Natl. Acad. Sci. USA 87, 6311-6315.

Görlach, J., Volrath, S., Knauf-Beiter, G., Hengy, G., Beckhove, U., Kogel, K. H., Oostendorp, M., Staub, T., Ward, E., Kessman, H. \& Ryals, J. (1996). Benzothiadiazole, a novel class of inducers of systemic acquired resistance, activates gene expression and disease resistance in barley. Plant Cell 8, 629-643. 
Gosti, F., Beaudoin, N., Serizet, C., Webb, A. A. R., Vartanian, N. \& Giraudat, J. (1999). ABl1 protein phosphatase $2 \mathrm{C}$ is a negative regulator of abscisic acid signaling. Plant Cell 11, 18971909.

Grant, M. \& Lamb, C. (2006). Systemic immunity. Curr. Opin. Plant Biol. 9, 414-420.

Gurr, S. J. \& Rushton, P. J. (2005). Engineering plants with increased disease resistance: how are we going to express it? Trends Biotechnol. 23, 283-290.

Haghighat, A., Mader, S., Pause, A. \& Sonenberg, N. (1995). Repression of CAP-dependent translation by $4 \mathrm{E}$-binding protein-1 - competition with p220 for binding to eukaryotic initiation factor-4E. EMBO J. 14, 5701-5709.

Hagiwara, Y., Komoda, K., Yamanaka, T., Tamai, A., Meshi, T, Funada, R., Tsuchiya, T., Naito, S. \& Ishikawa, M. (2003). Subcellular localization of host and viral proteins associated with tobamovirus RNA replication. EMBO J. 22, 344-353.

Hammond, S. M., Caudy, A. A. \& Hannon, G. J. (2001). Post-transcriptional gene silencing by double-stranded RNA. Nature Rev. (Genet.) 2, 110-119.

Hammond-Kosack, K. E. \& Jones, J. D. G. (1996). Resistance gene-dependent plant defense responses. Plant Cell 8, 1773-1791.

Hammond-Kosack, K. E., \& Parker, J. E. (2003). Deciphering plant-pathogen communication: fresh perspectives for molecular resistance breeding. Curr. Opin. Biotechnol. 14, 177-193.

Hanley-Bowdoin, L., Settlage, S. B. \& Robertson, D. (2004). Reprogramming plant gene expression: a prerequisite to geminivirus DNA replication. Mol. Plant Pathol. 5, 149-156.

Hari, V., Siegel, A., Rozek, D. \& Timberlake, W. E. (1979). The RNA of Tobacco etch virus contains poly(A). Virology 92, 568-571.

He, P., Shan, L. \& Sheen, J. (2007). Elicitation and suppression of microbe-associated molecular pattern-triggered immunity in plant-microbe interactions. Cell Microbiol. 9, 1385-1396.

Heath, M. C. (2000). Hypersensitive response-related death. Plant Mol. Biol. 44, 321-334.

Hellmann, G. M., Shaw, J. G. \& Rhoads, R. E. (1988). In vitro analysis of tobacco vein mottling virus Nla cistron: evidence for a virus-encoded protease. Virology. 163, 554-562. 
Hellwald, K. H. \& Palukaitis, P. (1995). Viral-RNA as a potential target for 2 independent mechanisms of replicase-mediated resistance against Cucumber mosaic virus. Cell 83, 937946.

Herold, J. \& Andino, R. (2001). Poliovirus RNA replication requires genome circularization through a protein-protein bridge. Mol. Cell 7, 581-591.

Hong, J. K., Yun, B. W., Kang, J. G., Raja, M. J., Kwon, E., Sorhagen, K., Chu, C., Wang, Y., \& Loake, G. (2008). Nitric oxide function and signalling in plant disease resistance. J. Exp. Bot. 59, 147-154.

Huber, S. C., MacKintosh, C \& Kaiser, W. M. (2002). Metabolic enzymes as targets for 14-3-3 proteins. Plant Mol. Biol. 50, 1053-1063.

Hückelhoven, R. (2007). Cell wall-associated mechanisms of disease resistance and susceptibility. Annu. Rev. Phytopathol. 45, 101-127.

Hull, R. (2002). Matthews' Plant Virology. Academic Press.

Igarashi, D., Ishida, S., Fukazawa, J. \& Takahashi, Y. (2001). 14-3-3 proteins regulate intracellular localization of the bZIP transcriptional activator RSG. Plant Cell 13, 2483-2497.

Ishikawa, M., Obata, F., Kumagai, T. \& Ohno, T. (1991). Isolation of mutants of Arabidopsis thaliana in which accumulation of Tobacco mosaic virus coat protein is reduced to low levels. Mol. Gen. Genet. 230, 33-38.

Ishikawa, M., Naito, S. \& Ohno, T. (1993). Effects of the tom1 mutation of Arabidopsis thaliana on the multiplication of Tobacco mosaic virus RNA in protoplasts. J. Virol. 67, 5328-5338.

Ishikawa, M. \& Okada, Y. (2004). Replication of tobamovirus RNA. Proc. Jpn. Acad. Ser. B Phys. Biol. Sci. 80, 215-222.

Jahn, M., Paran, I., Hoffmann, K., Radwanski, E. R., Livingstone, K. D., Grube, R. C., Aftergoot, E., Lapidot, M. \& Moyer, J. (2000). Genetic mapping of the Tsw locus for resistance to the Tospovirus Tomato spotted wilt virus in Capsicum spp. and its relationship to the Sw- 5 gene for resistance to the same pathogen in tomato. Mol. Plant Microb. Interact. 13, 673-682.

Jenner, C. E., Sanchez, F., Nettleship, S. B., Foster, G. D., Ponz, F. \& Walsh, J. A. (2000). The cylindrical inclusion gene of Turnip mosaic virus encodes a pathogenic determinant to the Brassica resistance gene TuRB01. Mol. Plant Microb. Interact. 13, 1102-1108. 
Johansen, E., Edwards, M. C. \& Hampton, R. O. (1994). Seed transmission of viruses: current perspectives. Annu. Rev. Phytopathol. 32, 363-386.

Jones, J. D. G \& Dangl, J. L. (2006). The plant immune system. Nature 444, 323-329.

Kasschau, K. D. \& Carrington, J. C. (1998). A counterdefensive strategy of plant viruses: Suppression of post-transcriptional gene silencing. Cell 95, 461-470.

Kasschau, K. D. \& Carrington, J. C. (2001). Long-distance movement and replication maintenance functions correlate with silencing suppression activity of potyviral HC-Pro. Virology 285, 71-81.

Kasschau, K. D., Cronin, S. \& Carrington, J. C. (1997). Genome amplification and long-distance movement functions associated with the central domain of Tobacco etch potyvirus helper component-proteinase. Virology 228, 251-262.

Kawano, T. (2003). Roles of the reactive oxygen species-generating peroxidase reactions in plant defense and growth induction. Plant Cell Rep. 21, 829-837.

Keen, N. T. (1990). Gene-for-gene complementarity in plant-pathogen interactions. Annu. Rev. Genet. 24, 447- 463.

Kerk, D., Bulgrien, J., Smith, D. W., Barsam, B., Veretnik, S., \& Gribskov, M. (2002). The complement of protein phosphatase catalytic subunits encoded in the genome of Arabidopsis. Plant Physiol. 129, 908-925.

Khan, M. A. \& Goss, D. J. (2004). Phosphorylation states of translational initiation factors affect mRNA cap binding in wheat. Biochemistry 43, 9092-9097.

Kim, C. Y. \& Zhang, S. (2004). Activation of a mitogen-activated protein kinase cascade induces WRKY family of transcription factors and defense genes in tobacco. Plant J. 38, 142-151.

Király, L., Barna B. \& Király, Z. (2007). Plant Resistance to Pathogen Infection: Forms and Mechanisms of Innate and Acquired Resistance. J. Phytopathol. 155, 385-396.

Kjemtrup, S., Sampson, K. S., Peele, C. G., Nguygen, L. V., Conkling, M. A., Thompson, W. F. \& Robertson, D. (1998). Gene silencing from plant DNA carried by a Geminivirus. Plant J. 14, $91-100$.

Koornneef, A. \& Pieterse, C. M. J. (2008). Cross talk in defense signaling. Plant Physiol. 146, 839-844. 
Kragler, F., Curin, M., Trutnyeva, K., Gansch, A. \& Waigmann, E. (2003). MPB2C, a microtubule associated plant protein binds to and interferes with cell-to-cell transport of Tobacco mosaic virus movement protein. Plant Physiol. 132, 1870-1883.

Kunik, T., Salomon, R., Zamir, D., Navot, N., Zeidan, M., Michelson, I., Gafni, Y. \& Czosnek, H. (1994). Transgenic tomato plants expressing the Tomato yellow leaf curl virus capsid protein are resistant to the virus. BioTechnology 12, 500-504.

Kunkel, B.N. \& Brooks, D. M. (2002). Cross talk between signaling in pathogen defense. Curr. Opin. Plant. Biol. 5, 325-31.

Laín, S., Riechmann, J. L. \& Garcla, J. A. (1990). RNA helicase: a novel activity associated with a protein encoded by a positive strand RNA virus. Nucl. Acids Res. 18, 7003-7006.

Lamb, C. \& Dixon, R. A. (1997). The oxidative burst in plant disease resistance. Annu. Rev. Plant Physiol. Plant Mol. Biol. 48, 251-275.

Lapidot, M., Gafny, R., Ding, B., Wolf, S., Lucas, W. J. \& Beachy, R. N. (1993). A dysfunctional movement protein of Tobacco mosaic virus that partially modifies the plasmodesmata and limits virus spread in transgenic plants. Plant J. 4, 959-970.

Lartey, R., Ghoshroy, S. \& Citovsky, V. (1998). Identification of an Arabidopsis thaliana mutation (vsm1) that restricts systemic movement of tobamoviruses. Mol. Plant-Microbe Interact. 11, 706709.

Le, H., Tanguay, R. L., Balasta, M. L., Wei, C. C., Browning, K. S., Metz, A. M., Goss, D. J. \& Gallie, D. R. (1997). Translation initiation factors elFiso4G and elF-4B interact with the poly(A)binding protein and increase its RNA binding activity. J. Biol. Chem. 272, 16247-16255.

Lee, J. Y. \& Lucas, W. J. (2001). Phosphorylation of viral movement proteins-regulation of cellto-cell trafficking. Trends Microbiol. 9, 5-7.

Lellis, A. D., Kasschau, K. D., Whitham, S. A. \& Carrington, J. C. (2002). Loss-of susceptibility mutants of Arabidopsis thaliana reveal an essential role for elF(iso)4E during potyvirus infection. Curr Biol. 12, 1046-1051.

Léonard, S., Plante, D., Wittmann, S., Daigneault, N., Fortin, M. G. \& Laliberte, J. F. (2000). Complex formation between potyvirus $\mathrm{VPg}$ and translation eukaryotic initiation factor $4 \mathrm{E}$ correlates with virus infectivity. J. Virol. 74, 7730-7737. 
Levis, C. \& Astier-Manifacier, S. (1993). The 50 untranslated region of PVY RNA, even located in an internal position, enables initiation of translation. Virus Genes 7, 367-379.

Ligterink, W., Kroj, T., zurNieden, U., Hirt, H. \& Scheel, D. (1997) Receptor-mediated activation of a MAP kinase in pathogen defense of plants, Science 276, 2054-2057.

Lin, T. A., Kong, X. M., Haystead, T. A., Pause, A., Belsham, G., Sonenberg, N. \& Lawrence, J. C. (1994). PHAS-I as a link between mitogen-activated protein kinase and translation initiation. Science 266, 653-656.

Liu, J. Z., Blancaflor, E. B. \& Nelson, R. S. (2005). The Tobacco mosaic virus 126-kilodalton protein, a constituent of the virus replication complex, alone or within the complex aligns with and traffics along microfilaments. Plant Physiol. 138, 1853-1865.

Loake, G \& Grant, M. (2007). Salicylic acid in plant defence- the players and protagonists. Curr. Opin. Plant Biol. 10, 466-472.

Lucas, W. J., \& Gilbertson, R. L. (1994). Plasmodesmata in relation to viral movement within leaf tissues. Annu. Rev. Phytopathol. 32, 387- 411.

MacFarlane, S. A. \& Davies, J. W. (1992). Plants transformed with a region of the 201-kilodalton replicase gene from Pea early browning virus RNA1 are resistant to virus-infection. Proc. Natl. Acad. Sci. USA 89, 5829-5833.

Mackey, D., Belkhadir, Y., Alonso, J. M., Ecker, J. R. \& Dangl, J. L. (2003). Arabidopsis RIN4 is a target of the type III virulence effector AvrRpt2 and modulates RPS2-mediated resistance. Cell 112, 379-389.

Mackintosh, C., Lyon, G. D. \& Mackintosh, R. W. (1994). Protein phosphatase inhibitors activate anti-fungal defence responses of soybean cotyledons and cell cultures. Plant J. 5, 137-147.

Mader, S., Lee, H., Pause, A. \& Sonenberg, N. (1995). The translation initiation-factor EIF-4E binds to a common motif shared by the translation factor EIF-4-gamma and the translational repressors 4E-binding proteins. Mol. Cell. Biol. 15, 4990-4997.

Mahajan, S. K., Chisholm, S. T., Whitham, S. A., and Carrington, J. C. (1998). Identification and characterization of a locus (RTM1) that restricts long-distance movement of Tobacco etch virus in Arabidopsis thaliana. Plant J. 14, 177-186. 
Malamy, J., Carr, J. P., Klessig, D. F. \& Raskin, I. (1990). Salicylic acid - a likely endogenous signal in the resistance response of tobacco to viral-infection. Science 250, 1002-1004.

Marcotrigiano, J., Gingras, A.-C., Sonenberg, N. \& Burley, S.K. (1999). Cap-dependent translation initiation in eukaryotes is regulated by a molecular mimic of elF4G. Mol. Cell 3, 1-20.

Martin, G. B. (1999). Functional analysis of plant disease resistance genes and their downstream effectors. Curr. Opin. Plant Biol. 2, 273-279.

Martin, G. B., Brommonschenkel, S. H., Chunwongse, J., Frary, A., Ganal, M. W., Spivey, R., Wu, T. Y., Earle, E. D. \& Tanksley, S. D. (1993). Map-based cloning of a protein-kinase gene conferring disease resistance in tomato. Science 262, 1432-1436.

Mauch-Mani, B. \& Slusarenko, A. J. (1993). Arabidopsis as a model host for studying plant-pathogen interactions. Trends Microbiol. 7, 265-70.

Mayda, E., Marqués, C., Conejero, V. \& Vera. P. (2000a) Expression of a pathogen-induced gene can be mimicked by auxin insensitivity. Mol. Plant. Microbe Interact. 13, 23-31.

Mayda, E., Mauch-Mani, B. \& Vera, P. (2000b). Arabidopsis dth9 mutation identifies a gene involved in regulating disease susceptibility without affecting salicylic acid-dependent responses. Plant Cell. 12, 2119-2128.

Maule, A. J., Leh, V. \& Lederer, C. (2002). The dialogue between viruses and hosts in compatible interactions. Curr. Opin. Plant Biol. 5, 279-284.

McHale, L., Tan, X., Kochl, P. \& Michelmore, R. W. (2006). Plant NBS-LRR proteins: adaptable guards. Genome Biol. 7, 212.

Merlot, S., Gosti, F., Guerrier, D., Vavasseur, A. \& Giraudat, J. (2001). The ABI1 and ABI2 protein phosphatases $2 \mathrm{C}$ act in a negative feedback regulatory loop of the abscisic acid signaling pathway. Plant J. 25, 295-303.

Meskiene, I., Bogre, L., Glaser, W., Balog, J., Brandstotter, M., Zwerger, K., Ammerer, G., \& Hirt, H. (1998). MP2C, a plant protein phosphatase 2C, functions as a negative regulator of mitogen-activated protein kinase pathways in yeast and plants. Proc. Natl. Acad. Sci. USA. 95, 1938-1943. 
Mestre, P., Brigneti, G. \& Baulcombe, D. C. (2000). An Ry-mediated resistance response in potato requires the intact active site of the Nla proteinase from Potato virus Y. Plant J. 23, 653661.

Metraux, J. P., Goy, P. A., Staub, T., Speich, J., Steinemann, A., Ryals, J. \& Ward, E. (1991). Induced systemic resistance in cucumber in response to 2,6-dichloro-isonicotinic acid and pathogens. En: Advances in Molecular Genetics of Plant-Microbe Interactions, Vol $1 \mathrm{H}$. Hennecke \& D. P. S. Verma, eds.), pp. 432-439. Kluwer Academic Publishers, Dordrecht.

Meyer, K., Leube, M. P. \& Grill, E. (1994). A protein phosphatase 2C involved in ABA signal transduction in Arabidopsis thaliana. Science 264, 1452-1455.

Meyers, B. C., Kozik, A., Griego, A., Kuang, H. \& Michelmore, R. W. (2003). Genome-wide analysis of NBS-LRR encoding genes in Arabidopsis. Plant Cell 15, 809-834.

Minich, W., Balasta, M., Goss, D. \& Rhoads R. (1994). Chromatographic resolution of in vivo phosphorylated and nonphosphorylated eukaryotic translation initiation-factor EIF-4E increased cap affinity of the phosphorylated form. Proc. Natl. Acad. Sci. USA 91, 7668-7672.

Mizoguchi, T., Ichimura, K. \& Shinozaki, K. (1997). Environmental stress response in plants: the role of mitogen-activated protein kinases. Trends Biotechnol. 15, 15-19.

Mourrain, P., Beclin, C., Elmayan, T., Feuerbach, F., Godon, C., Morel, J. B., Jouette, D., Lacombe, A. M., Nikic, S., Picault, N., Remoue, K., Sanial, M., Vo, T. A. \& Vaucheret, H. (2000). Arabidopsis SGS2 and SGS3 genes are required for post-transcriptional gene silencing and natural virus resistance. Cell 101, 533-542.

Mur, L. A. J., Kenton, P. Lloyd, A. J., Ougham, H. \& Prats, E. (2008). The hypersensitive response; the centenary is upon us but how much do we know? J. Exp. Bot. 59, 501-520.

Murphy, J. F., Rhoads, R. E., Hunt, A. G. \& Shaw, J. G. (1990). The VPg of Tobacco etch virus RNA is the $49-k D a$ proteinase or the Nterminal 24-kDa part of the proteinase. Virology. 178, 285-288.

Loake, G and Grant, M. (2007). Salicylic acid in plant defence- the players and protagonists. Curr. Opin. Plant Biol. 10, 466-472.

Muslin, A. J., Tanner, J. W., Allen P. M. \& Shaw, A. S. (1996). Interaction of 14-3-3 with signaling proteins is mediated by the recognition of phosphoserine. Cell 84, 889-897. 
Nakagami, H., Pitzschke, A. \& Hirt, H. (2005). Emerging MAP kinase pathways in plant stress signaling. Trends Plant Sci. 10, 339-346.

Nicaise, V., German-Retana, S., Sanjuan, R., Dubrana, M.P., Mazier, M., Maisonneuve, B., Candresse, T., Caranta, C. \& LeGall, O. (2003). The eukaryotic translation initiation factor 4E controls lettuce susceptibility to the Potyvirus Lettuce mosaic virus. Plant Physiol. 132, 12721282.

Nicolas, O., Dunnington, S. W., Gotow, L. F., Pirone, T. P. \& Hellmann, G. F. (1997). Variations in the VPg protein allow a potyvirus to overcome va gene resistance in tobacco. Virology 237, 452-459.

Noueiry, A. O. \& Ahlquist, P. (2003). Brome mosaic virus RNA replication: revealing the role of the host in RNA virus replication. Annu. Rev. Phytopathol. 41, 77-98.

Ohshima, K., Taniyama, T., Yamanaka, T., Ishikawa, M. \& Naito, S. (1998). Isolation of a mutant of Arabidopsis thaliana carrying two simultaneous mutations affecting Tobacco mosaic virus multiplication within a single cell. Virology 243, 472-481.

Pause, A., Belsham, G. J., Gingras, A.-C., Donzé, O., Lin, T. A., Lawrence, J. C. \& Sonenberg, N. (1994). Insulin-dependent stimulation of protein-synthesis by phosphorylation of a regulator of 5'-CAP function. Nature $371,762-767$.

Pedley, K. F. \& Martin, G. B. (2005). Role of mitogen-activated protein kinases in plant immunity. Curr. Opin. Plant Biol. 8, 541-547.

Peng, C.-Y., Graves, P. R., Thomas, R. S., Wu, Z., Shaw, A. S. \& Piwnica-Worms, H. (1997). Mitotic and G2 checkpoint control: regulation of 14-3-3 protein binding by phosphorylation of Cdc25c on serine 216. Science 277, 1501-1505.

Pieterse, C. M. \& van Loon, L.C. (1999). Salicylic acid-independent plant defence pathways. Trends Plant Sci. 4, 52-58.

Preiss, T. \& Hentze, M. W. (2003). Starting the protein synthesis machine: eukaryotic translation initiation. Bioessays 25, 1201-1211.

Qu, F., Ren, T. \& Morris, T. J. (2003). The coat protein of Turnip crinkle virus suppresses posttranscriptional gene silencing at an early initiation step. J. Virol. 77, 511-522.

Rajamäki, M. L. \& Valkonen, J. P. T. (1999). The 6K2 protein and the VPg of Potato 
virus $A$ are determinants of systemic infection in Nicandra physaloides. Mol. Plant Microbe Interact. 12, 1074-1081.

Rathjen, J. P. \& Moffett, P. (2003). Early signal transduction events in specific plant disease resistance. Curr. Opin. Plant. Biol. 6, 300-306.

Ren, T., Qu, F. \& Morris, T. J. (2000). HRT gene function requires interaction between a NAC protein and viral capsid protein to confer resistance to Turnip crinkle virus. Plant Cell 12, 19171926.

Restrepo-Hartwig, M. A. \& Carrington, J. C. (1994). The Tobacco etch potyvirus 6-kilodaltons protein is membrane bound-associated and involved in viral replication. J. Virol. 68, 2388-2397.

Revers, F., Le Gall, O., Candresse, T. \& Maule, A. J. (1999). New advances in understanding the molecular biology of plant/potyvirus interactions. Mol. Plant Microbe Interact. 12, 367-376.

Riechmann, J. L., Lain, S. \& Garcia, J. A. (1989). The genome-linked protein and 5' end RNA sequence of Plum pox potyvirus. J. Gen. Virol. 70, 2785-2789.

Ritzenthaler, C. (2005). Resistance to plant viruses: old issue, news answers? Curr. Opin. Biotechnol. 16, 118-122.

Roberts, M. R. (2003). 14-3-3 proteins find new partners in plant cell signalling. Trends Plant Sci. 8, 218-223.

Rodriguez, P. L., Leube, M. P. \& Grill, E. (1998). Molecular cloning in Arabidopsis thaliana of a new protein phosphatase 2C (PP2C) with homology to ABI1 and ABI2. Plant Mol. Biol. 38, 879883.

Rojas, M. R., Zerbini, F. M., Allison, R. F., Gilbertson, R. L. \& Lucas, W. J. (1997). Capsid protein and helper component-proteinase function as potyvirus cell-to-cell movement proteins. Virology 237, 283-295.

Robaglia, C. \& Caranta, C. (2006). Translation initiation factors: a weak link in plant RNA virus infection. Trends Plant Sci. 11, 40-45.

Romeis, T., Piedras, P., Zhang, S. Q., Klessig, D. F., Hirt, H. \& Jones, J. D. G. (1999). Rapid Avr9- and Cf-9-dependent activation of MAP kinases in tobacco cell cultures and leaves: Convergence of resistance gene, elicitor, wound, and salicylate responses. Plant Cell 11, 273287. 
Romero-Puertas, M. C., Perazzolli, M., Zago, E. D. \& Delledonne, M. (2004). Nitric oxide signalling functions in plant-pathogen interactions. Cell Microbiol. 6, 795-803.

Ruffel, S., Dussault, M. H., Palloix, A., Moury, B., Bendahmane, A., Robaglia, C. \& Caranta, C. (2002). A natural recessive resistance gene against Potato virus $Y$ in pepper corresponds to the eukaryotic initiation factor 4E (elF4E). Plant J. 32, 1067-1075.

Ruffel, S., Gallois, J. L., Moury, B., Robaglia, C., Palloix, A. \& Caranta, C. (2006). Simultaneous mutations in translation initiation factors eIF4E and eIF(iso)4E are required to prevent pepper veinal mottle virus infection of pepper. J. Gen. Virol. 87, 2089-2098.

Ruffel, S., Gallois, J. L., Lesage, M. L. \& Caranta, C. (2005). The recessive potyvirus resistance gene pot-1 is the tomato orthologue of the pepper pvr2-elF4E gene. Mol. Genet. Genomics 274, 346-353.

Ryals, J. A., Neuenschwander, U. H., Willits, M. G., Molina, A., Steiner, H. Y., \& Hunt, M. D. (1996). Systemic Acquired Resistance. Plant Cell. 8, 1809-1819.

Sato, M., Nakahara, K., Yoshii, M., Ishikawa, M. \& Uyeda, I. (2005). Selective involvement of members of the eukaryotic initiation factor $4 \mathrm{E}$ family in the infection of Arabidopsis thaliana by potyviruses. FEBS Lett. 579, 1167-1171.

Schaad, M. C., Haldeman-Cahill, R., Cronin, S., \& Carrington, J. C. (1996). Analysis of the VPgproteinase (Nla) encoded by the Tobacco etch potyvirus: Effects on mutations on subcellular transport, proteolytic processing, and genome amplification. J. Virol. 70, 7039-7048.

Schaad, M. C., Jemsen, P. E. \& Carrington, J. C. (1997). Formation of plant RNA virus replication complexes on membranes: role of an endoplasmic reticulum-targeted viral protein. EMBO J. 16, 4049-4059.

Schaad, M. C., Anderberg, R. J. \& Carrington, J. C. (2000). Strain-specific interaction of the Tobacco etch virus Nla protein with the translation initiation factor elF4E in the yeast two-hybrid system. Virology 273, 300-306.

Scheel, D. (1998). Resistance response physiology and signal transduction. Curr. Opin. Plant Biol. 1, 305-310. 
Scheper, G. C., van Kollenburg, B., Hu, J., Luo, Y., Goss, D. J., \& Proud, C. G. (2002). Phosphorylation of eukaryotic initiation factor $4 \mathrm{E}$ markedly reduces its affinity for capped mRNA. J. Biol. Chem. 277, 3303-3309.

Schweighofer, A., Hirt, H. \& Meskiene, I. (2004). Plant PP2C phosphatases: emerging functions in stress signaling. Trends Plant Sci. 9, 236-243.

Shah, J., Kachroo, P. \& Klessig, D. F. (1999). The Arabidopsis ssi1 mutation restores pathogenesis-related gene expression in npr1 plants and renders defensin gene expression salicylic acid dependent. Plant Cell 11, 191-206.

Sheen, J. (1998). Mutational analysis of protein phosphatase $2 \mathrm{C}$ involved in abscisic acid signal transduction in higher plants. Proc. Natl. Acad. Sci. USA 95, 975-980.

Shen, K. A., Meyers, B. C., Islam-Faridi, M. N., Chin, D. B., Stelly, D. M. \& Michelmore, R. W. (1998). Resistance gene candidates identified using PCR with degenerate primers map to resistance genes clusters in lettuce. Mol. Plant Microbe Interact. 11, 815-823.

Shenolikar, S. (1994). Protein serine/threonine phosphatases - new avenues for cell regulation. Annu. Rev. Cell. Biol. 10, 55-86.

Shetty, N. P., Jørgensen, H. J. L., Jensen J. D., Collinge D. B. \& Shetty H. S. (2008). Roles of reactive oxygen species in interactions between plants and pathogens. Eur. J. Plant Pathol. 121, 267-280.

Shirasu, K. \& Schulze-Lefert, P. (2003). Complex formation, promiscuity and multi-functionality: protein interactions in disease-resistance pathways. Trends Plant Sci. 8, 1360-1385.

Shukla, D. D., Ward, C. W. \& Bunt, A. A. (1994). The Potyviridae. C.A.B. International, Wallingford, UK.

Siaw, M. F. E., Shahabuddin, M., Ballard, S., Shaw, J. G. \& Rhoads, R. E. (1985). Identification of a protein covalently linked to the 5 ' terminus of tobacco vein mottling virus RNA. Virology 142 , 134-143.

Smyth, D. R. (1999). Gene silencing: Plants and viruses fight it out. Curr. Biol. 9, R100-102.

Song, W. Y., Wang, G. L., Chen, L. L., Kim, H. X., Pi, L. Y., Holsten, T., Gardner, J., Wang, B., Zhai, W. X., Zhu, L. H., Fauquet, C. \& Ronald, P. (1995). A receptor kinase-like protein encoded by the rice disease resistance gene Xa21. Science 270, 1804-1806. 
Soriano, J. M., Vilanova, S., Romero, C., Yacer, G. \& Badenes, M. L. (2005). Characterization and mapping of NBS-LRR resistance gene analogs in apricot (Prunus armeniaca L.) Theor. Appl. Genet. 110, 980-989.

Spoel, H. S., Johnson, J. S. \& Dong, X. (2007). Regulation of tradeoffs between plant defenses against pathogens with different lifestyles. Proc. Natl. Acad. Sci. USA 104, 18842-18847.

Stange, C. (2006). Plant-virus interactions during the infective process. Cien. Inv. Agr. 33, 1-18.

Staskawicz, B. J., Ausubel, F. M., Baker, B. J., Ellis, J. G. \& Jones, J. D. G. (1995). Molecular genetics of plant disease resistance. Science 268, 661-667.

Takahashi, H., Suzuki, M., Natsuaki, K., Shigyo, T., Hino, K., Teraoka, T., Hosokawa, D. \& Ehara, Y. (2001). Mapping the virus and host genes involved in the resistance response in Cucumber mosaic virus-infected Arabidopsis thaliana. Plant Cell Physiol. 42, 340-347.

Takahashi, H., Kanayama, Y., Zheng, M. S., Kusano, T., Hase, S., Ikegami, M. \& Shah, J. (2004). Antagonistic interactions between the SA and JA signaling pathways in Arabidopsis modulate expression of defense genes and gene-for-gene resistance to Cucumber mosaic virus. Plant Cell Physiol. 45, 803-809.

Tenhaken, R., Levine, A., Brisson, L. F., Dixon, R. A. \& Lamb, C. (1995). Function of the oxidative burst in hypersensitive disease resistance. Proc. Natl. Acad. Sci. USA 92, 4158-4163.

Thomma, B. P., Pennínckx, I. A., Broekaert, W. F. \& Cammue, B. P. (2001).The complexity of disease signaling in Arabidopsis. Curr. Opin. Immunol. 13, 63-68.

Torres, M. A., Jones, J. D. G. \& Dangl, J. L. (2006). Reactive oxygen species signaling in response to pathogens. Plant Physiol. 141, 373-378.

Tsujimoto, Y., Numaga, T., Ohshima, K., Yano, M., Ohsawa, R., Goto, D., Naito, S. \& Ishikawa, M. (2003). Arabidopsis tobamovirus multiplication (TOM) 2 locus encodes a transmembrane protein that interacts with TOM1. EMBO J. 22, 335-343.

Uknes, S., Winter, A. M., Delaney, T., Vernooij, B., Morse, A., Friedrich, L., Nye, G., Potter, S., Ward, E. \& Ryals, J. (1993). Biological induction of systemic acquired-resistance in Arabidopsis. Mol. Plant-Microb. Interact. 6, 692-698. 
Urcuqui-Inchima, S., Haenni, A. \& Bernardi, F. (2001). Potyvirus proteins: a wealth of functions. Virus Res. 74, 157-175.

Van der Biezen, E. A. \& Jones, J. D. G. (1998) Plant disease resistance proteins and the genefor-gene concept. Trends Biochem. Sci. 23, 454-456.

Van der Hoorn, R. A. L., de Wit, P. J. G. M. \& Joosten, M. H. A. J. (2002) Balancing selection favors guarding resistance proteins. Trends Plant Sci. 7, 67-71.

van Kan, J. A. L., Joosten, M. H. A. J., Wagemakers, C. A. M., van den Berg-Velthuis, G. C. M., de Wit, P.J. G. M. (1992). Differential accumulation of mRNAs encoding extracellular and intracellular PR proteins in tomato induced by virulent and avirulent races of Cladosporium fulvum. Plant Mol. Biol. 20, 513-527.

van Regenmortel, M. H. V. (2000). Virus taxonomy: The classification and nomenclature of viruses. The Seventh Report of the International Committee on the Taxonomy of Viruses. Academic Press, San Diego, USA.

Vera, P., Tornero, P. \& Conejero, V. (1993). Cloning and expression analysis of a viroid-induced peroxidase from tomato plants. Mol Plant Microbe Interact. 6, 790-794.

Verchot, J., Koonin, E. V. \& Carrington, J. C. (1991). The 35-kDa protein from the N-terminus of a potyviral polyprotein functions as a third virus-encoded proteinase. Virology 185, 527-535.

Vernooij, B., Friedrich, L., Morse, A., Reist, R., Kolditzjawhar, R., Ward, E., Uknes, S., Kessmann, H. \& Ryals, J. (1994). Salicylic-acid is not the translocated signal responsible for inducing systemic acquired-resistance but is required in signal transduction. Plant Cell 6, 959965.

Wang, D., Harper, J. F. \& Gribskov, M. (2003) Systematic trans-genomic comparison of protein kinases between Arabidopsis and Saccharomyces cerevisiae. Plant Physiol.132, 2152-2165.

Wang, D., Pajerowska-Mukhtar, K., Culler, A. H. \& Dong, X. (2007). Salicylic acid inhibits pathogen growth in plants through repression of the auxin signaling pathway. Curr. Biol. 17, 1784-1790.

Wang, W.. \& Shakes, D. C. (1996). Molecular evolution of the 14-3-3 protein family. J. Mol. Evol. 43, 384-398. 
Ward, E. R., Uknes, S. J., Williams, S. C., Dincher, S. S., Wiederhold, D. L., Alexander, D. C., Ahlgoy, P., Metraux, J. P. \& Ryals, J. A. (1991). Coordinate gene activity in response to agents that induce systemic acquired-resistance. Plant Cell 3, 1085-1094.

Warren, R. F., Henk, A., Mowery, P., Holub, E. \& Innes, R. W. (1998). A mutation within the leucine-rich repeat domain of the Arabidopsis disease resistance gene RPS5 partially suppresses multiple bacterial and downy mildew resistance genes. Plant Cell 10, 1439-1452.

Wei, C. C., Balasta, M. L., Ren, J. \& Goss, D. J. (1998). Wheat germ poly(A) binding protein enhances the binding affinity of eukaryotic initiation factor $4 \mathrm{~F}$ and (iso) $4 \mathrm{~F}$ for cap analogues. Biochemistry 37, 1910-1916.

Wera, S. \& Hemmings, B. A. (1995). Serine/threonine protein phosphatases. Biochem. J. 311, 17-29.

Whitham, S., Dinesh-Kumar, S. P., Choi, D., Hehl, R., Corr, C. \& Baker, B. (1994). The product of the Tobacco mosaic virus resistance gene N: similarity to TOLL and the Interleukin-1 receptor. Cell 78, 1101-1115.

Whitham, S., McCormick, S. \& Baker, B. (1996). The $\mathrm{N}$ gene of tobacco confers resistance to Tobacco mosaic virus in transgenic tomato. Proc. Natl. Acad. Sci. USA 93, 8776-8781.

Whitham, S., Yamamoto, M., Carrington, J. C. (1999). Selectable viruses and Arabidopsis thaliana gain-of-susceptibility mutants. Proc. Natl. Acad. Sci. USA 96, 772-777.

Whitham, S. A., Anderberg, R. J., Chisholm, S. T. and Carrington, J. C. (2000). Arabidopsis RTM2 gene is necessary for specific restriction of Tobacco etch virus and encodes an unusual small heat shock-like protein Plant Cell 12, 569-582.

Wilson, I. D., Neill, S. J. \& Hancock, J. T. (2008). Nitric oxide synthesis and signalling in plants. Plant Cell Environ. 31, 622-631.

Wittman , S., Chatel, H., Fortin, M. G. \& Laliberte, J.-F. (1997). Interaction of the viral protein genome linked of Turnip mosaic potyvirus using the yeast two-hybrid system. Virology 234, 8492.

Xie, Z., Fan, B., Chen, C. \& Chen, Z. (2001). An important role of an inducible RNA-dependent RNA polymerase in plant antiviral defense. Proc. Natl Acad. Sci. USA 98, 6516-6521. 
Xie, Z. X., Johansen, L. K., Gustafson, A. M., Kasschau, K. D., Lellis, A. D., Zilberman, D., Jacobsen, S. E. \& Carrington, J. C. (2004). Genetic and functional diversification of small RNA pathways in plants. PLOS Biol. 2, 642-652.

Xing, T., Higgins, V.J. \& Blumwald, E. (1997). Race-specific elicitors of Cladosporium fulvum promote translocation of cytosolic components of NADPH oxidase to the plasma membrane of tomato cells. Plant Cell 9, 249-259.

Yamanaka, T., Imai, T., Satoh, R., Kawashima, A., Takahashi, M., Tomita, K., Kubota, K., Meshi, T., Naito, S. \& Ishikawa, M. (2002). Complete inhibition of tobamovirus multiplication by simultaneous mutations in two homologous host genes. J. Virol. 76, 2491-2497.

Yamanaka, T., Ohta, T., Takahashi, M., Meshi, T., Schmidt, R., Dean, C., Naito, S. \& Ishikawa, M. (2000). TOM1, an Arabidopsis gene required for efficient multiplication of a tobamovirus, encodes a putative transmembrane protein. Proc. Natl. Acad. Sci. USA 97, 10107-10112.

Yang, S. J., Carter, S. A., Cole, A. B., Cheng, N. H. \& Nelson, R. S. (2004). A natural variant of a host RNA-dependent RNA polymerase is associated with increased susceptibility to viruses by Nicotiana benthamiana. Proc. Natl Acad. Sci. USA 101, 6297-6302.

Yang, Y., Shah, J. \& Klessig, D. F. (1997). Signal perception and transduction in plant defense responses. Genes Dev. 11, 1621-1639.

Yoshii, M., Nishikiori, M., Tomita, K., Yoshioka, N., Kozuka, R., Naito, S., \& Ishikawa, M. (2004). The Arabidopsis cucumovirus multiplication 1 and 2 loci encode translation initiation factors $4 \mathrm{E}$ and 4G. J. Virol. 78, 6102.

Yoshii, M., Yoshioka, N., Ishikawa, M., \& Naito, S. (1998a). Isolation of an Arabidopsis thaliana mutant in which accumulation of Cucumber mosaic virus coat protein is delayed. Plant J. 13, 211-219.

Yoshii, M., Yoshioka, N., Ishikawa, M. \& Naito, S. (1998b). Isolation of an Arabidopsis thaliana mutant in which the multiplication of both Cucumber mosaic virus and Turnip crinkle virus is affected. J. Virol. 72, 8731-8737.

Yu, D., Fan, B., MacFarlane, S. A. \& Chen, Z. (2003). Analysis of the involvement of an inducible Arabidopsis RNA-dependent RNA polymerase in antiviral defense. Mol. Plant Microb. Interact. 16, 206-216. 
Zeizer, J., Delledonne, M., Mishina, T., Severi, E., Sonoda, M. \& Lamb, C. (2004). Genetic elucidation of nitric oxide signaling in incompatible plant-pathogen interactions. Plant Physiol. 136, 2875-86.

Zha, J., Harada, H., Yang, E., Jockel, J., \& Korsmeyer, S. J. (1996). Serine phosphorylation of death agonist $B A D$ in response to survival factor results in binding to 14-3-3 not BCL-XL. Cell 87, 619-628.

Zhang, S. \& Klessig, D. F. (1997). Salicylic acid activates a 48-kD MAP kinase in tobacco. Plant Cell 9, 809-824.

Zhang, S. Q. \& Klessig, D. F. (1998). The tobacco wounding-activated mitogen-activated protein kinase is encoded by SIPK. Proc. Nat. Acad. Sci. USA 95, 7225-7230.

Zhang, S. \& Klessig, D. F. (2001). MAPK cascade in plant defense signaling. Trends Plant Sci. 6, 520-527.

Zipfel, C. (2008). Pattern-recognition receptors in plant innate immunity. Curr. Opin. Immunol. 20, 10-16.

Zuberek, J., Wyslouch-Cieszynska, A., Niedzwiecka, A., Dadlez, M., Stepinski, J., Augustyniak, W., Gingras, A. C., Zhang, Z., Burley, S. K., Sonenberg, N., Stolarski, R., \& Darzynkiewicz, E. (2003). Phosphorylation of elF4E attenuates its interaction with mRNA 5' cap analogs by electrostatic repulsion: Intein-mediated protein ligation strategy to obtain phosphorylated protein. RNA 9, 52-61. 